PROGRESS IN BECONING ESTABLISHED

IN FARMING

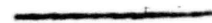

A Thesis

Presented to

the Faculty of the Graduate School

The University of Missourd

In Partial Fulfillment

of the Requirements for the Degree

Master of Sclence

by

Ted Lee Jones

August 1958 
The undersigned, appointed by the Dean of the Graduate Faculty, have examined a thesis entitled

\section{PROGRESS IN BECOMING ESTABLISHED IN FARMING}

presented by

Ted Lee Jones

a candidate for the degree of

Master of Sclence

and hereby certify that in their opinion it is worthy of acceptance.

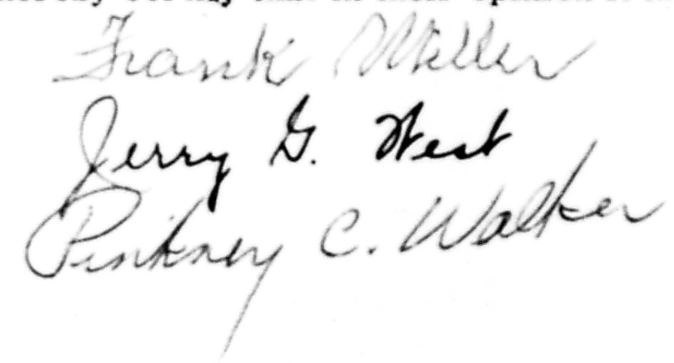




\section{ACKNOWLEDGMENT}

The writer is grateful for the able advice and guidance given by

Dr. Frank Miller, Department of Agrlcultural Bconomics, in the developmont and presentation of this thesis. 
TABLE OF CONTENTS

CHAPTER

PAGE

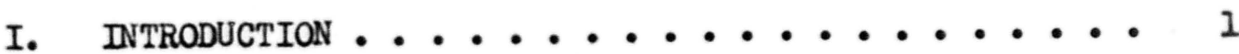

Objective of the Study ............ 2

Method of Investigation . . . . . . . 4

Summary of Related Research . . . . . • 5

II. DESCRIPTION OF THE AREA . . . . . . . 16

III. FINDINGS . . . . . . . . . . 31

Pertinent Facts About Begdnning Farmers ..... 31

Procedure in Analysis . . . . . . . 33

Sources of Starting Capital ......... 31

Borrowed Funds . . . . . . . . 37

The Farm Buslness . . . . . . . 46

The Farm Business in 1955 . . . . . . 69

Factors Which Were Tested Statistically . . . 107

Major Success and Failure Factors Faced

By Beginning Farmers . . . . . . 110

IV. SUMMARY AND CONCLUSIONS . . . . . . . . 116

Summary ............ 16

Conclusions . . . . . . . . . 125

BIBLIOGRAPHY . . . . . . . . . 128

APPENDIX .............................. 131 


\section{LIST OF TABLES}

TABLE

PAGE

I. Number of Farms in FIfteen Northern Missourl and

Fourteen Southern Iowa Counties, 1950-1954 . . .

II. Average Size of Farm and Value of Iand and Bulldings

In Fyfteen Northern Missouri and Fourteen

Southern Iowa Counties, 1950-1954. . . . . 24

III. Number of Commercial Farms and Acres of Cropland

Harvested in Flfteen Northern Missouri and

Fourteen Southern Iowa Counties, 1949-1954 . . - 26

IV. Tenure Conditions in Fifteen Northern Missouri and

Fourteen Southern Iow Counties, 1950-1954 • • 27

V. OffFarm Work by Farm Operators in Fifteen Northern

Missour1 and Fourteen Southern Iowa Counties,

1949-1954 ..............

VI. Pertinent Facts About 1953 Beginning Farmers in

Fifteen Northern Missouri and Fourteen Southern

Iows Counties, 1953 . . . . . . 32

VII. Major Source of Beginning Funds of 1953 Beginning

Farmers in Fifteen Northern Missouri and Fourteen

Southern Iow Counties, According to Type of

Tenure in 1953 (Number receiving funds from

each source) . . . . . . . . 34 
VIII. Second Major Source of Beginning Funds of 1953

Beginning Farmers in Fifteen Northern Missourl and Fourteen Southern Iowa Counties, According to Type of Tenure in 1953 . . . . . . .

IX. Average Interest Rates, Terms, and Amount of Non-Real Estate Credit Used by Beglnning Farmers During 1953 in Fifteen Northern Missouri and Fourteen Southern Iowa Counties, by Type of Tenure ..............

X. Average Interest Rates, Term, and Amount of NonReal Bstate Credit, by Source, Used by Beginning Farmers During 1953 in Fifteen Northern Missouri and Fourteen Southern Iowa Counties . . . .

XI. Type and Amount of Family Help Received by Beginning Farmers During 1953 in Fifteen Northern Missouri and Fourteen Southern Iowa Counties, by Tenure Groups .........

XII. Size of Business in Terms of Total Acres Operated by Beginning Farmers in Fifteen Northern Missouri and Fourteen Southern Iows Counties During 1953, by Tenure Croups (Number of Operators in Each

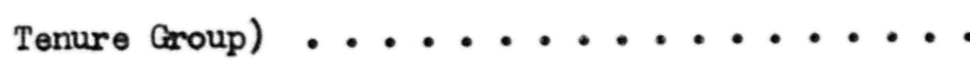


XIII. Size of Business in Terms of Acres of Cropland Operated by Beginning Farmers in Fifteen Northern Missour1 and Fourteen Southern Iowe Counties During 1953, by Tenure Groups (Number of Operators In Each Tenure Group) .......... 48

XIV. Size of Business in Terms of Acres of Corn, Wheat and Soybeans Grown by Beginning Farmers in Fifteen Northern Missour1 and Fourteen Southern Iowa Counties During 1953, By Tenure Groups (Number of Operators in Each Tenure Group) . . . . 49

XV. Size of Business by Beginning Farmers in Fifteen Northern Missour1 and Fourteen Southern Iow Counties During 1953, in Terms of Productive Man Work Units (Number of P.M.W.U. Required by Bach Group) .................. 50 A

XVI. Distribution of Labor Among the Livestock Enterprises Carried by Beginning Farmers in Fifteen Northern Missouri and Fourteen Southern Iowa Counties During 1953, by Tenure Groups (Number of P.M.W.U. Used by Each Group) .......... 51

XVII. Months of Hired, Unpald Family, and Operator's

Labor, and Total Months of Labor Available on the Farms of Beginning Farmers in Fifteen Northern Missourl and Fourteen Southern Iowa Counties, During 1953, by Tenure Groups (Months Used by Tenure Groups). 52A 
XVIII. Size of Business in Terms of Total Farm Assets Under Operator's Control of Beginning Farmers in Fifteen Northern Missouri and Fourteen Southern Iowa Counties, According to Type of Tenure, January 1, 1953 . . . . . . 53

XIX. Assets, Liabilities, and Net Worth of Beginning

Farmers in F1fteen Northern Missouri and Fourteen Southern Iowa Counties, According to Type of Tenure, January 1, 1953 and December 31, $1953 . . \quad 54$

XX. Percent of Total Rented Land Held Under Written Lease and Number of Oral Leases Held by Beginning Fermers in Fifteen Northern Missouri and Fourteen Southern Iowa Counties in 1953 by Tenure Groups . . 57

XXI. Labor Share Arrangements of Beginning Farmers in

Fifteen Northern Missouri and Fourteen Southern Iowa Counties During 1953, by Tenure Groups (Number of Operators in Bach Group) ...... 59 XXII. Type of Landlord of Kost Valuable Tracts Rented by Beginning Farmers in Fifteen Northern Missouri and Fourteen Southern Iowa Counties in 1953 by Tenure Groups (Number of Operators in Bach Group) .... 60 
XXIII. Type of Landlord on Second Nost Valuable Tract Rented by Beginning Farmers in Fifteen Northern Missouri and Fourteen Southern Iowa Counties In 1953 by Tenure Croups (Number of Operators in Each Group) ............

XXIV. Wost Important Source of Land Farmed by Beginning Farmers in Fifteen Northern Missouri and Fourteen Southern Iow Counties During 1953, by Tenure Croups (Number of Operators in Each Croup) . •

XXV. Second Most Important Source of Land Farmed by Beginning Farmers in Fifteen Northern Milsouri and Fourteen Southern Iowa Counties During 1953, By Tenure Croups (Number of Operators in Each Group) ...............

XXVI. Net Family Income of Beginning Farmers in Fifteen Northern Missour1 and Fourteen Southern Iowa Counties During 1953, by Tenure Groups (Number of Operators in Bach Group) ........

XXVII. Type of Employment, Time Spent, and Income From Off-Farm Work by Beginning Farmers (Operator and Wife) in Fifteen Northern Missouri and Fourteen Southern Iowa Counties, During 1953, According to Type of Tenure ......... 
TABLE

XXVIII. Labor Income to Family, Labor and Management Income to Operator and Returns to Management in 1953, Beginning Farmers in Fifteen Northern Missouri and Fourteen Southern Iowa Counties, According to Type of Temure . . . . . . . . 70

XXIX. S1ze of Businesses Operated by Farmers tho Started In Business in 1953 and S1ze in 1955, Messured in Productive Man Work Units by Tenure Groups, Fifteen Northern Missouri and Fourteen Southern Iowa Counties . . . . . . . . 72

xox. Efficiency in Use of Labor by Operators Who Started in Farming in 1953 As Shown by Work Units Accomplished Per Man Bquivaient, Fifteen Northern Missouri and Fourteen Southern Iowa Counties, According to Type of Tenure . . . . . . 74

XXXI. Productive Man Work Units Used on DAfferent Types of Livestock in 1955, by Beginning Farmers in Flfteen Northern M1ssour1 and Fourteen Southern Iowa Counties According to Type of Tenure When They Started Farming in 1953 (P.M.W.U. Used by Bach Tenure Group) ........... 75 
TABLE

XXXII. Months of Hired, Unpaid Pamily and Operator's Labor, and Total Months of Labor Available on the Farms of Beglnning Farmers in Fifteen Northern Missouri and Fourteen Southern Iowa Counties During 1955 by Type of Tenure of the Operators When They Started

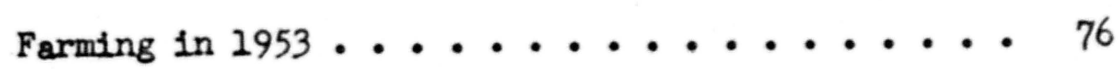

XXXIII. Total Business Capital Avallable to Farm Operators Who Started Farming in 1953, At The TIme They Started and on January 1, 1955, by Tenure Groups, Fifteen Northern Missour1 and Fourteen Southern Iom Counties . . . . . . . . 78

XXXIV. Total Assets, Llabllities, and Net Worth of Beglnning Farmers in Fifteen Northern Missouri and Fourteen Southern Iowa Counties, According to Type of Tenure When They Started Farming, on January 1, 1953 and December 31, 1955 . . . 80 XOXV. Average Interest Rate, Terms, and Amount of NonReal Estate Cred1t Used During 1955 by Beginning Farmers in Fifteen Northern Missouri and Fourteen Southern Iowa Counties, According to Type of Tenure When Borrower Started Farming in 1953 . • 
TABLE

XXXVI. Type of Off-Farm Work Done by 1953 Beginning Farmers and Their Wives in 1955 and Average Receipts From This Source, Fifteen Northern Missouri and Fourteen Southern Iowa Count1es . . . . . . . 88

xoXVII. Type and Amount of Famdly Help Received by Beginning Farmers During 1955 in Fyeteen Northern Missouri and Fourteen Southern Iow Counties, According to Type of Tenure in 1953 . . . . . . . 90

XXXVIII. Percentage of Operators tho Started Farming in 1953

Who Had Written, Oral, and Mixed Leases in That Year and in 1955, Fifteen Northern Missouri and Fourteen Southern Iow Counties . . . . . 92

XXXIX. Number of Operators Without Compensation Clauses and Percentage With Compensation Clauses in Leases in 1955 by Tenure Groups and Type of Tenure When They Started Farming in 1953, Fifteen Northern Missouri and Fourteen Southern Iowa Counties, (Number of Operators in Tenure Group) ..... 94

XI. Number of Operators Who Started Farming in 1953 with Different Types of Labor Agreements in 1955, According to Type of Tenure at the Tims They Started, Fifteen Northern Missouri and Fourteen Southern Iows Counties ........ 95 
XII. Type of Owner of Most Valuable Tract Rented by

Beginning Farmers in Fifteen Northern Missouri and

Fourteen Southern Iow Counties During 1955

(Number of Operators in Bach Tenure Group) . . . 97

XIII. Most Important Source of Land Farmed by Beginning

Farmers in F1fteen Northern Missouri and Fourteen

Southern Iowa Counties During 1955, by Type of

Tenure When They Started Farming in 1953 (Number

of Operators in Bach Tenure Group) ...... 97A

XIIII. Second Most Important Source of Land Farmed by

Beginning Parmers in Flfteen Northern Missouri and

Fourteen Southern Iow Counties During 1955, by

Type of Tenure When They Started Farming in 1953

(Number of Operators in Each Tenure Croup) . . .

XIIV. Average Net Income of Families Who Started Farming in

1953 by Sources and Tenure Groups, FIfteen Northern

Milsour1 and Fourteen Southern Iow Counties . . 100

XIV. Gross Receipts. From the Sale of Livestock and Other

Farm Products by Farmers Who Started in Business

in 1953, Fifteen Northern Missouri and Fourteen

Southern Iowa Counties, During 1953 and 1955 . . 101 
TABLE

PAGE

XIVI. Comparison of Off-Farm Incomes of Beginning Farmers For the Years of 1953 and 1955, Fifteen Northern Missouri and Fourteen Southern Iowa Counties . . 103 XIVII. Composition of Net Family Incomes of Beginning

Farmers in Fifteen Northern Missourl and Fourteen

Southern Iowa Counties During 1955, by Type of

Tenure When They Started Farming in 1953 . . . 105

XIVIII. Labor Income to Family, Operator, and Returns to Management, 1953 Beginning Farmers, Fifteen Northern Missouri and Fourteen Southern Iowa Counties, According to Type of Tenure in 1953 • 106

XIIX. The ilost Important Factor Limiting the Success of Beginning Farmers in Fyfteen Northern Missourl and Fourteen Southern Iowa Counties, by Type of Tenure When They Started Farming in 1953 (Number of Operators in Each Tenure Group) . . 113

L. Second Major Factor Lumiting the Success of the Beginning Farmers in Fifteen Northern Missouri and Fourteen Iow Counties, by Type of Tenure When They Started Farming in 1953 (Number of Operators In Each Tenure Group) ...... 114 


\section{IIST OF FIGURES}

FIGURE

PAGE

1. Northern Missourl Counties Where 1953 Beginning

Farmers Were Interviewed . . . . . . 13

2. Southern Iowa Counties Where 1953 Beginning

Farmers Were Interviewed .......... 14

3. Major Soll Areas of Fifteen Missouri Counties . . 15

4. Principal So1l Association Areas in Fourteen

Southern Iow Counties . . . . . . . 16

5. General Land Class Areas in Fifteen Northern

Missour1 Counties . . . . . . . 18 


\section{IIST OF APPENDIX TABLES}

TABLE

I. Simple Average of Prices Received by Missouri and Iow Farmers, 1953-1955 . . . . . . 131 


\section{CHAPTER I.}

\section{INTRODUCTION}

Getting established in farming has never been an easy task. Even in the dars of the Homestead Act, with so called "freen land, the task was difflcult. Iand as space was a gift of nature, but the development costs for agricultural uses were tremendous when measured in terms of labor, self sacriflce, hardshlps, and money required for building a home and improving the land.

The task of getting established in faming appears to be more difflcult today than it was in the past. Iand and improvements can be rented; but the investment in woridng capltal in 1953 often exceeded the value of the entire farm business in the period of settlement. The difficulties encountered in gaining control of the necessary resources for operating an adequate farm busdness seem to be increasing. Management problems are greater than in frontior days, too. Superior skdil Is needed to combine, coordinate, adjust, and maintain the factors of production required for a profltable farm business.

In this study, no attempt is made to try to determine how meny pegiming farmers are needed as replacements each year, or how to keep young people on the fam. Attention is centered on the procedures that have been used in getting started and the factors such as size and type pe business, tenure status, educational training and experience that contributed to the success of the people who made the start in 1953. 
OBJECTIVES OF THE STUDY

The investigation has bean guided by the following objectives:

1. To determine how young people got started in farming in 1953 in the pasture livestock areas of South Central Iowa and North Central Messour1.

2. To determine the procedures that have proven to be mot onccessul.

3. To find the factors that contributed most to success.

4. To develop standards that can be used as guides by joung people who are interested in appraising their chances of success. Need for the Study.

Dats from the 1954 Census of Agriculture show that 36.0 per cent of the farmers in North Central Missourl and South Central Iove are over fiftymive years of age. Kany of these operators will soon retire. Young people will take their places. It 18 important for these young people to know the amount of beginning capital required; how wach famdly halp is needed; the of of farm that wil give the best chance of succeeding; the types of enterprises required for stable incomes; the best tenure arrangements; and other facts that will help theen to decide wether or not they should attempt to otart farming.

Members of the Agrioultural College and Extension staffs frequently are asked, What is the best way for a young man to start farming todays" Obvlously, the answer can be different for ach Individuel and for ach set of soil, climatic, and marketing conditions. However, general principles can be devaloped that can be used as guides 
In answering these questions. Some of these principles should become evident in the analysis of experiences of farmers who started in business in 1953. The young man who is trying to decide whether or not to make farming his occupation needs this type of information to guide hin to a decision.

The prospective ruture farmer wil know, tentatively, the approxdmate so of farm on which he plans to start, the types of enterprises he will Include in the business, the amount of otarting capital, and wether he will be a renter or an omer. If data are available to show the percentage of beginning farmers starting under conditions simlar to $\mathrm{Hll}$ o own, who have gained net worth rapldly, and the percentage who have not, he will have a better understanding of the risk involved than if he mat learn colely by trial.

Selecting an occupation is a very important st op in the life of every young person. The cholce needs to be considered very carefully. Llternative opportunities need to be weighed one againgt the other if a person wants to enter the occupation which will be most advantageous to him. There 1s a loss, not only to the individual, but to society, If a man spends several years in an occupation and then becomes an economic casualty. The individual and society would have advanced more if he had chosen an occupation in which he could become eatablished permanent $1 \mathrm{y}$. 
METHOD OF INVESTIGATION

In order to obtein dats for this anelyeis, a random selection of 112 geographical tovenships was made in fifteen Northern Missouri counties and an equal number of tomships in fourteen Southern Iove count1es. The names of farmers operating in these tomshipe were taken from the Agricultural Stablilsation and Conservation records in each county office. The records in these offices gave the most complete list that could be found. The lists were checked with people who had lived in the county for several years to get the names of farm operators tho had started in business in 1953. Operators that qual1fled were interviewed to get complete information about how they started their businesses and the financial progress they had made.

Missourl tomships, generally, are political tornships and do not follow the geographical subudivisions (thirty-six sections) found in Iora. Because of this fact, the names of farmers in two or three political tomships were obtained and superimposed on a map to get a complete list of those living in the geographic tornships.

To be included in the study, a beginning farmer had to meet the following conditions: (1) he mast have started farming for the firet time in 1953; (2) he had to be in position to make or help make the production plans and decisions for farm enterprises that required at least 90 ten-hour daye of productive Labor per year; (3) he had to be out of full-time formal school before 1953; (4) all or a substantial part of his income had to be derived from his contribution to the farm production; and (5) the farming operation had to be carried out in the 
sample tovensip. If the operator lived on the farm, the dwelling had to be in the sample tormship. If he did not live on the farm, the northern-most and west ern-most tract of land he operated had to be in the sample township.

The tomships included in the survey made up fourmevenths of the area in the twentymine counties. The information obtained about the farm business covered a three-year period, 1953-1955. An affort was made to get informstion from all of the people who started farming in 1953. In Milsour1, four operators wo had started in that year had quit farming and moved from the area. In Iova, 13 who had started were no longer farming; 4 were still in the area; and 9 had moved avay. This manuscript deals with the 152 records of those who started In 1953 and wee otill farming at the and of 1955.

\section{SUMYARY OF REILATED RESEARCH}

The Missouri-Iow investigation 18 part of the North Central Reglonal study of "fow Young Men Become Bstablished in Farming". This work wa undertaken by a sub-omindteo of the North Central Iand Tenure Research Comandtee, and a North Central Reglonal Committee (NC-15) that had an allocation of reglonal funds from the Undted States Department of Agriculture. The work of this coundtee has dealt with two brosd aspects of the general problen of getting started in farming: (I) problems of capital accumblation, tenure arrangements, resource allocation, and other aimilar items that influence the decision of an Individual who is seeiding to bocome established in farring, and (2) 
those problems associated with choice of an occupation and the impect of the choles upon farm people, including its impect upon allocation of farm land between beglnning and established operators.

Beneke and Pond ${ }^{l}$ interviewed beginning farmers in Southeastern Minnesota who had started to farm in 1946. They found that: (1) the farm omers had the largest net worth; (2) work for wges, either farm or nonfarm, had boen an undmportant source of capital with which these people had started; (3) help from relstives, together with money saved from service pay and subsistence received in the on-the-farm training program were the principal sources of funds; (4) twenty-tio percent of the beginning farmers used no credit; (5) the principal sources of credit for those who used it were: a. comererciel banks, and b. individuals (largely relatives); (6) their resources were often unbalanced In that they had a relatively large amount of labor compared to capital (7) the ovmer-operators who had the largest net worth were using the lesst capital and had the lowest earnings; and (8) the boginners with partnership agreements had the lowest net worth, but used the largest amount of cepitel and had the highest earnings.

Starrah ${ }^{2}$ studied farmers who started in business between 1930 and 1938. He found that the major problems encountered dealt with:

finsncial matters; (2) production of crpps and animels; (3) Insdequate

I Beneke, Raymond Ro, and Pond, George A., Starting Farming in Southesetern Minnesots, University of Minnesots dgricultural Experiment Station Bulletin 405, June 1950, pp. 19-20.

2Starrah, J. A., Problemes of Beginning Farmers in Iows, Iowa State College Research Bulletin 313, April 1943, page 516 . 
housing; (4) procedure of securing foundstion livestock; (5) obtaining good Land; (6) mangement, and (7) methods of securing equipment.

wor those who do not have near relatives who ove land, obtaining good land is the most defficult problem. ${ }^{3}$

In 1955, a Minnesota study by Pond, Swanson, and Cavert wa based on the experilences of 350 beginning farmers in Southern Kinnesota. Part I of the report ws based on s survey covering the experlences of a group of young men who had started farming largely during the pest five or dx years. The initisl eapital omed by the beginning farmers varled from nothing to $\$ 4,000$. The average at the time of starting was $\$ 4,700$. Nonfarm work and sevings from servlce pay were the principal mans of accumulating capital for voterans and farm work for nonveterans. The edght oun per cent who started farming as owner-cperstors borrowed approximately fifty per cent of the capital they used. The aightyutio per cent who started as tenants borroved only ten per cent. 4

The principal difficulties encountered in starting farming were reported to be "lack of avallable capital and credit", and "bbtaining a farm to operate". Relatives ware great help in overcoming these problems. Sixtguntine per cent of the real estate loans and thirty alght per cent of the chattel loans were obtained from individuals,

3Ib1d, page 518.

"Fond, George A., Swanson, Henning Wo, and Gavert, WHIiam I., Starting Farming Todsy, University of Minnesots Agricultural Bxperiment Station Builetin 428, April 1955, pp. 34-36. 
mostly relatives. Insurance companies, comercial benks, the Foderal Land Bank, and the Farmers Home Adminlotration all oupplied starting capital. Forty per cent of all borrowed funds at the start were secured by real estate mortgages. Thirty-two per cent were secured by chattel mortgages. Interest rates pald to comereial benks by beginning farmers were no higher then rates to other borrowers requesting the same type of losns. In some cases, loans were obtatned from relatives at lower rates than would have been charged by benks. 5

All of the begiming farmers increased their net worth during the per1od of study. The average amount wabout $\$ 2,200$ per year. Although ournings from farm operations accounted for the mojor portion of Income out of which asset. were accumalsted, they were rupplemented by average annual recelpts of $\$ 953$ from veterens' subsist ance payments, nonfarm enployment, and assistance from relstives. 6

There was no close association between incresse in net worth and size of farm, tenure or beginning net worth. Those with higher earnings apperently opent more for fandly living than those who received low 1ncomes. 7

Assistance from ralatives is an 1mportant factor in the success of starting farmers. It ma include favorable rental or purchase arrangements, advice and guldance, outrlght glfts, favorable credit

\section{${ }^{5}$ Ibld \\ ${ }^{6}$ Indd \\ 7 Io1d}


terma, free use of machinery, and some help with peak labor loads in caring for farm enterprises. 8

Frank D. Hansing 9 found in a Virginis study that the mot diff1cult problem for a young man to solve in getting started in farming is to find the money for a dow payment on the business. In that area, the process of starting on a small tract and adding to 1t, plece by piece, is now practiced much less than formerly. Few farmers during recent years have climbed the somcalled agricultural ladder. Work at nonfarm employment was more prevalent than had been expected. If the opportunity for rapid accumalation of capital by working in industry shouid decresse, farm youth vould f1nd 1t difflcult to get started in farm home owmership without substantial fanfly help.

Malvin G. Blase ${ }^{10}$ stated the chances for success of beginning farmere were enhanced mat erialy by starting odth a large business that permitted full seasonal use of equipment and provided for yearmound employment of the labor force. Fantly assietance halped some of the men to get started in a farm business, but in itself did not guarantee success.

\section{${ }^{8}$ Ib1d}

9Hansing, Frank D., "Buying a Farm With or Without Family Help", The Agricultural Situation, Volume 37, number 6, June 1953, pp. 7-8.

10 Melvin G. Blase, Wrocedures for Botablishing Farm Businesses in Missour1" ", (Unpubliahed Naster's thesis, University of Missouri, Columbia, Missouri, 1956), pp. 92-93. 
Marahall Harrls ${ }^{\text {Il }}$ suggests that a new type of agricultural ladder has appeared to replace the old one in transforring rights in farm businesses. The new ladder starts with a project agreement on the home farm. The boy serves an apprent1ceship and then enters into a partnership with his father. The next step 1s the transfer phase, where the young man mos into full omerehip.

Noore and Wayt ${ }^{12}$ found that partming farmers tand to follow about the saine combination of enterprises as rulletine farmere, with als ght Iy less intensity, particularly in developing livestocik enterprises. The principal reason why more partutine farmers had not gone to fullutine farding ws the diffleulty of butlding up a sufflelently profitable business whlle ot 1 ll working off the farm.

In discussing factor affecting saving and debt paying abilities by faudles on anall farms, Hendrel $x^{13}$ polnts out that the emphssis should be placed on Increasing production and income rather than reducing living expenses as a means of saving. Experiences of the families whose records were revlewed indlcated that incomes large enough to provide at the same time reasonably good levels of living

II Harris, Marshall, "The Agrlcultural Iadder", Land Economfes, August 1950, page 262.

12 Moore, H. R., and Wayt, W. A., The Part Time Route to Full Tyme Farming, Ohio Agricultural Bxperiment Station Research Bulietin 793, Sept ember 1956, page 4 .

13Hendrix, W. E., Capital Aceunalation br Feminses on Sind Farms in the Pledmont, Georgle Agrieultural Bxperiment Station Bulletin N. S. 8, August 1955, pp. 13-14. 
were essential to edther very modest sevings or safe credit transactions.

The description of the area where the farmers were interviewed for the study reported in this manuscript is presented in Chapter II. Chapter III contains the findings. This section includes an analysis of the farm businesses, a report of the sources and amount of income from off-farm work, and the importance of gifts recelved, based on type of tenure. The analysis includes data for 1953 and 1955. The summary and conclusions are presented in Chapter IV. 


\section{CHAPTER II.}

\section{DESCRIPTION OF THE AREA}

The area were the records were obtained is a part of the pasture Iivestock region of Northern Missourl and Southern Iow. The location of the counties where the beginning farmers were intervlewed is show In F1gures 1 and 2. The northwestern 11mit was Adams County, Iova. The southwestern I1ndt was Gentry County in Missourl. Jefferson County, Iow, was the northeastern limit and Shelby County, Missourl, was the southeastern lindt. The Mlssourl are actended two counties south from the Iows line in the extreme western part and three counties south In the sertern part. I.m, Kacon, and Shelby count1es were the greatest d1stance south. The are in Iovactended two count1es north from the Missourl Iine, including Mdams and Taylor counties on the west and Jefferson and Van Buren count1es on the east. Beef cattle and hogs are the dondnant enterprises in both otates, but substantial numbers of sheep are found on some farms.

\section{So11s}

The are 11 es in the glactal and loessial reglon. The predomInant upland soll serles are Karshall, Sharpsburg, Winterset, Grandy, Halg, Shelby, Lindley, Bdina, Wellen, Seymour, and Putnam, as shown in F1gures 3 and 4. Waukesha is found on the benches that parallel the streams, and Wabash and Lamour on the nood platns.

Shelby Loam is the domdnant soll type. It is largely of glacial origin, and 1s actensiveiy devaloped in the northern and western parts 


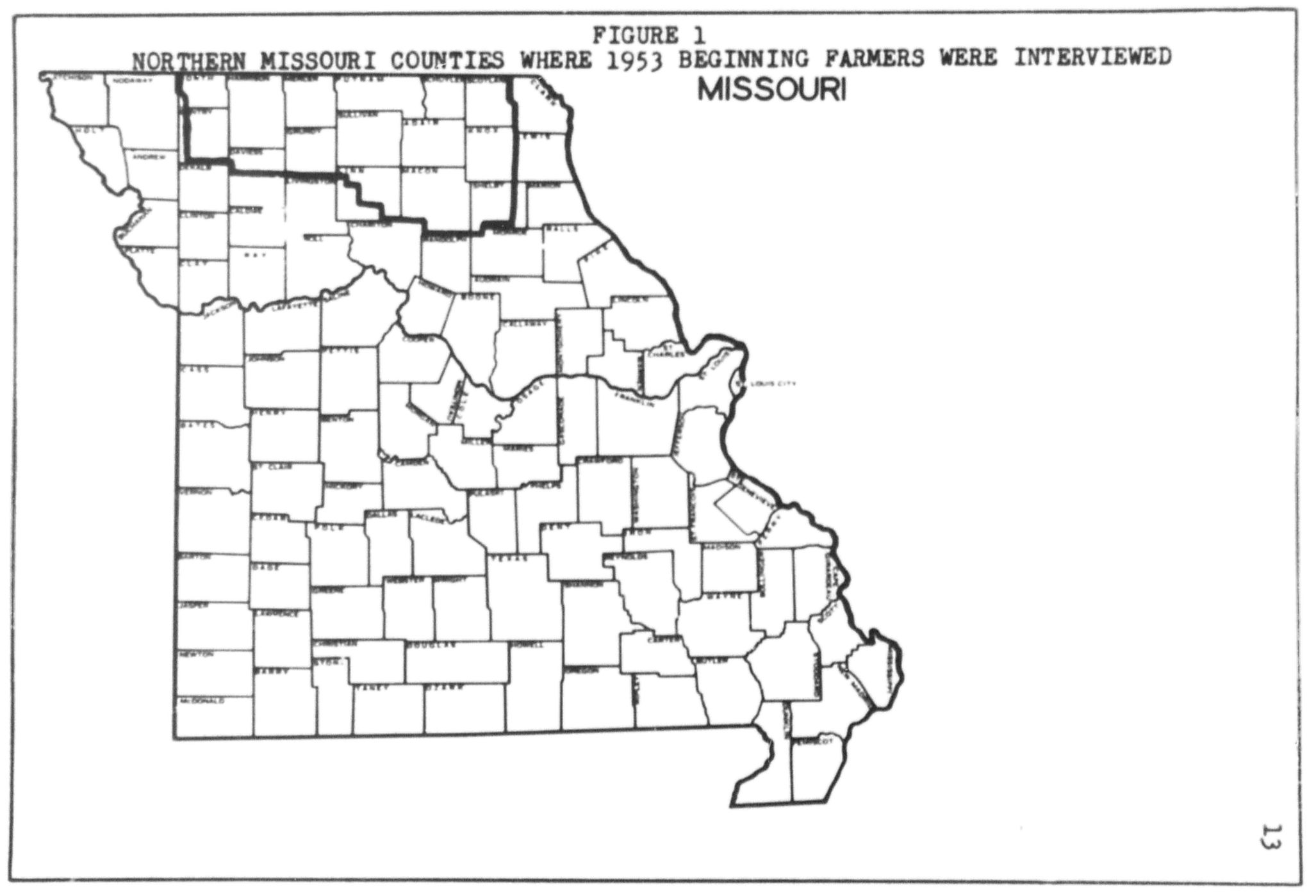




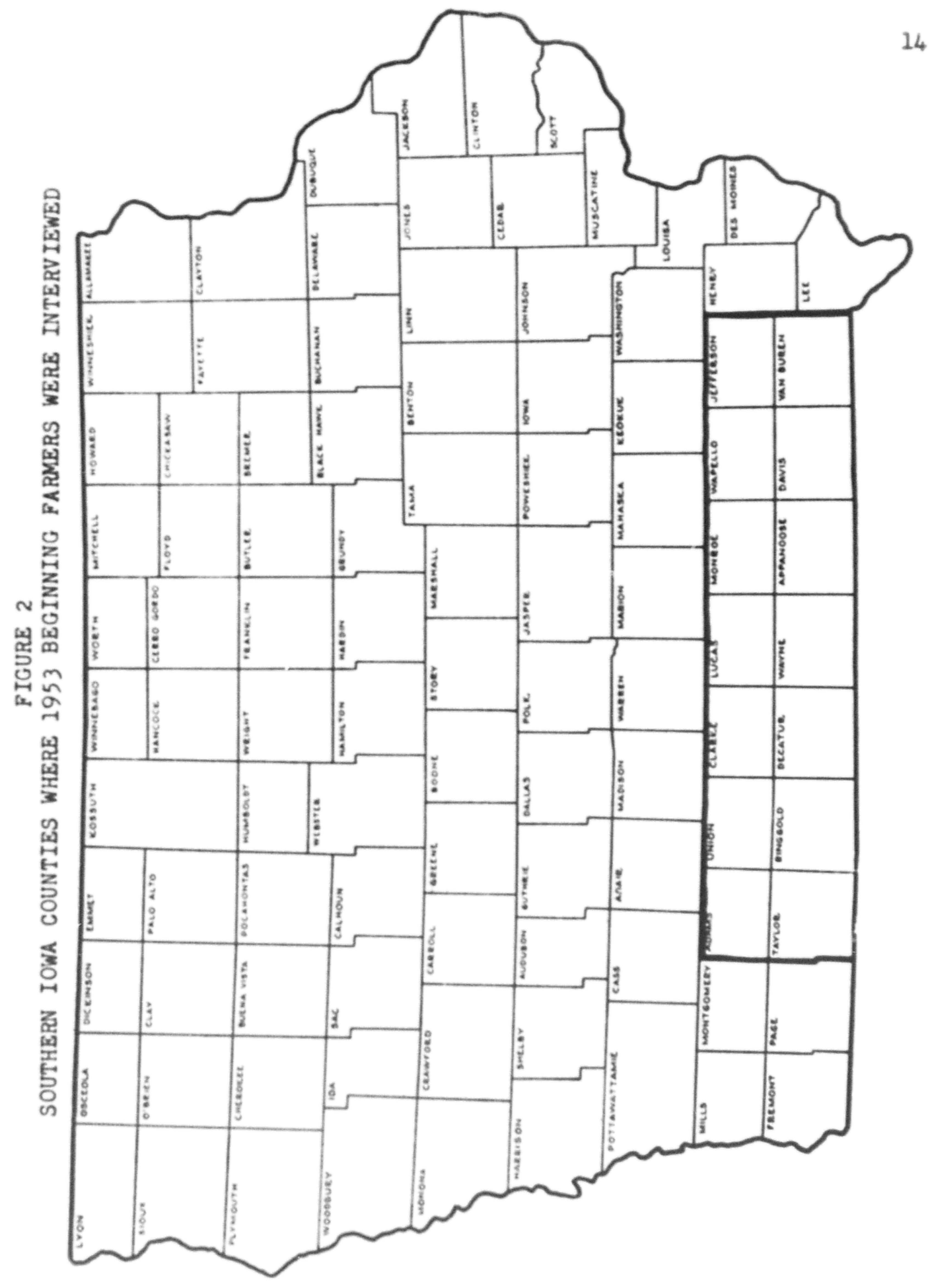




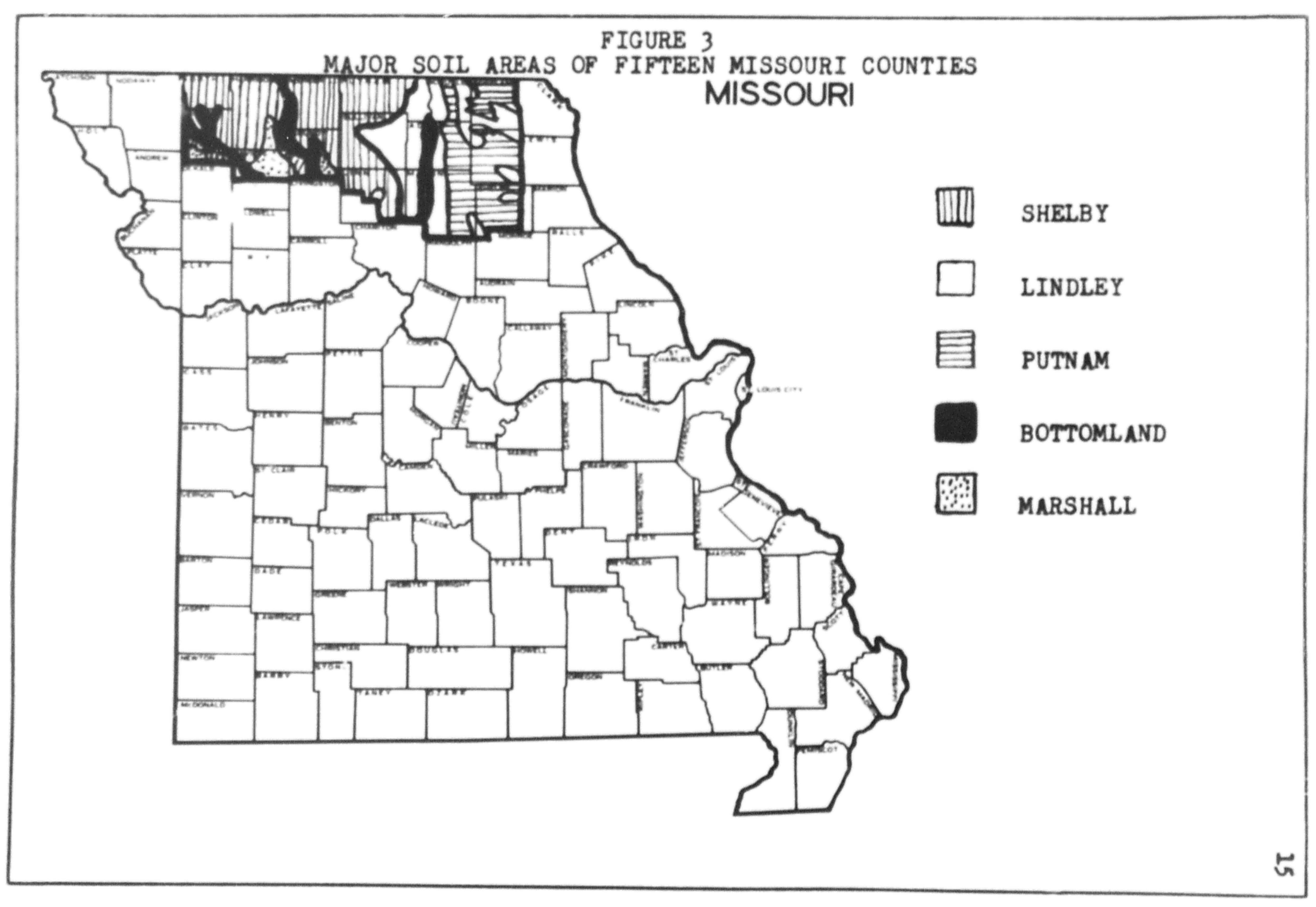


FIGURE 4

PRINCIPAL SOIL ASSOCIATION AREAS IN FOURTBEN SOUTHERN IOWA COUNTIBS

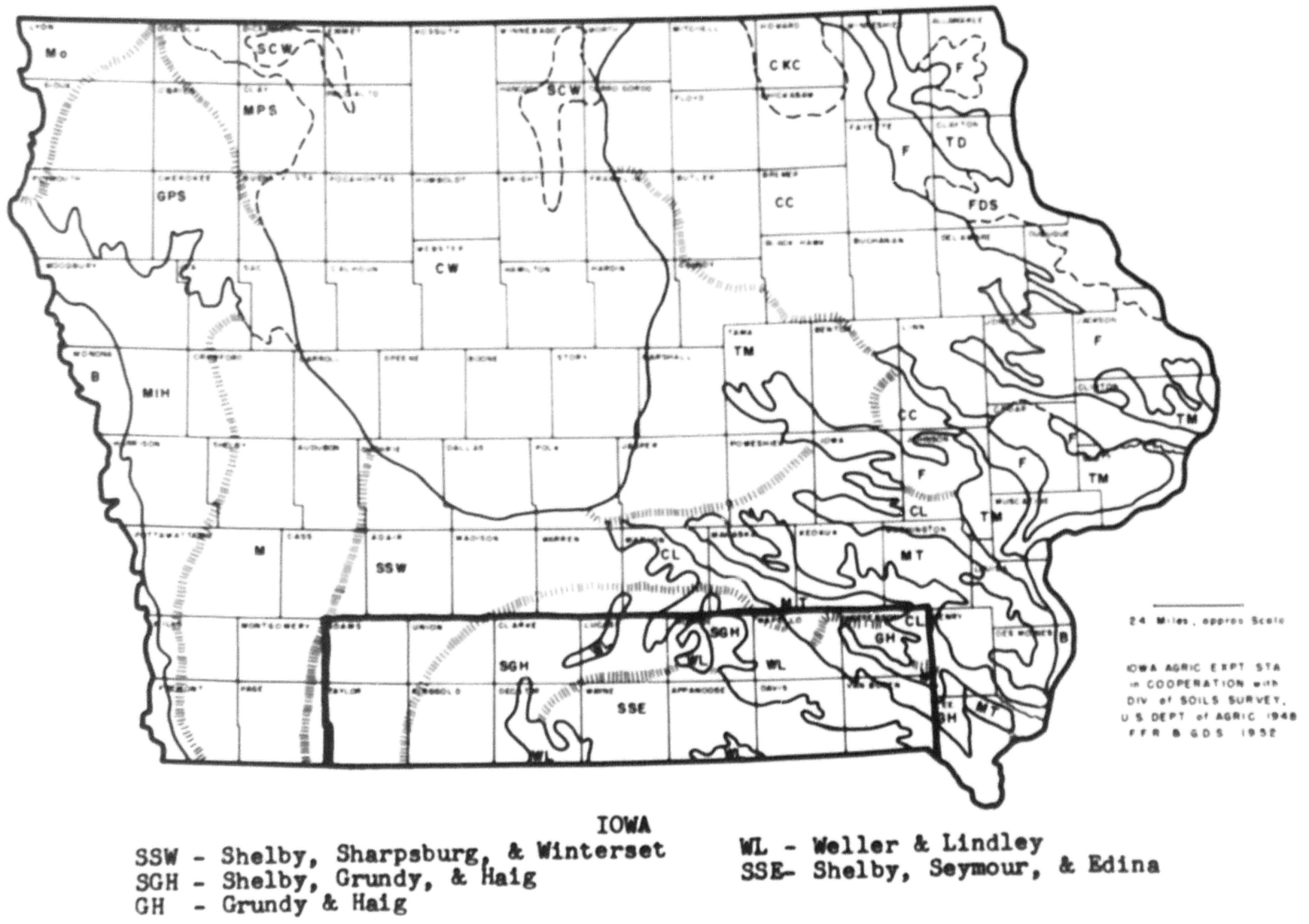


of Missourl and in South Central Iows. The surface features are gently rolling to moderately hilly. In general, the type is more rolling in Swllvan and Putnam count1es in Miseourl and Appanoose and Wayne counties in Iowa than in other parts of the area. It is one of the most easily eroded solls in the two states. Iosses from sheet erosion and gulying are serious problems in 1ts management. This condition influences the type of farming and large areas are left in grass. The greater part of the Shelby loam originally was prairie. Serious deterioration 18 evident on mall farms were it has been extensively cultivated. 14 It wa classed as average crop land by Lanpher ${ }^{15}$, as shove in Figure 5.

Indley Loam includes the rougher glacial land in both states. It represents nost of the timber land of the reglon. The topography varles from gently rolling in the ares adjoining the pratrle solls to very rolling or hilly near streams. A large part of the acreage is too steep for propitable cultivation. The Ifindley loan is not as productive as the Shelby loam, as shom in Figure 5. In general, the Ifindley losm 1s used for hay and pasture. Ifrestock production is the dowinant type of farming. It is not adapted to profitable grain

14viller, M. F., and Krusekopf, H. Ho, The Solis of Missourl, Univeradty of Kiseour College of Agriculture, Agricultural Experiment Station Bulletin 264, January 1929, pp. 34-37.

15 Ianpher, Buel F. Jr., Productivity of Fere Iand in Missourl, University of Helseour Agricultural Experiment Ststion Reseerch Bulletin 465, December 1950, pp. 6-8. 


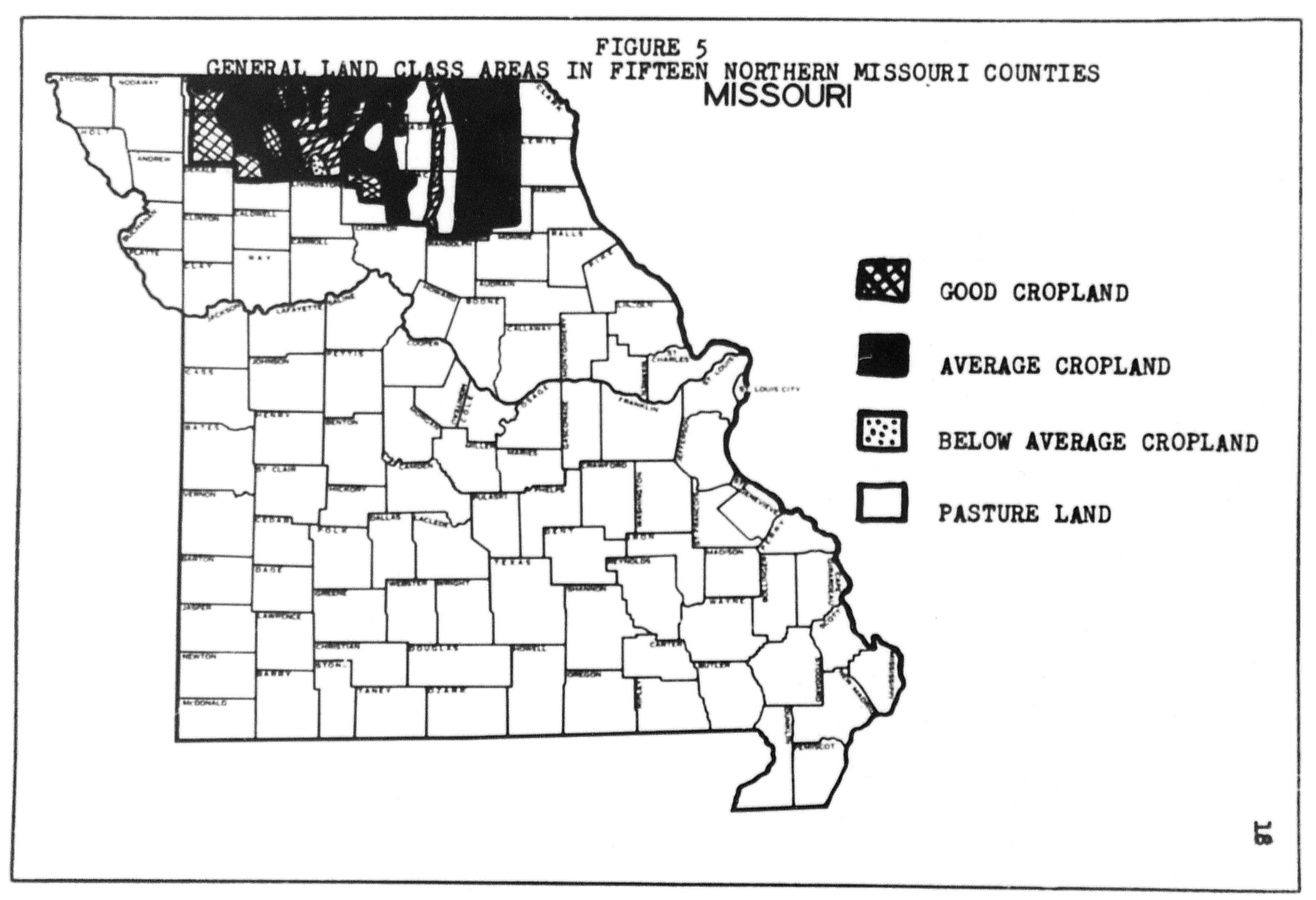


production. 16

Putnam Silt Loam is a level prairle soll, probably loessial in origin, and is found in the eastern part of llorth Hissouri. Practically all of it is in cultivation. The principal problem is poor internal drainsge. Corn, osts, whest, and soybeans are the most important crops grow. The prevalling type of agriculture is general farming. The ent erprises inalude feed grain, hay, and pasture which are used to raise and finish livestock for market. Putnam Silt Loam is better farm Land than Lindley Ioam. ${ }^{27}$

Marshall Silt Ioam is of loessial origin. It is a prairie soll and is the most important tjpe in Missourl from the agricultural point of view. The topography is undulating to gently rolling, with generally just enough slope to insure good drainege. It is the dominant corn soil in the ares included in the study. General farming is the prevalling type of organization. It combines cash crops with production of livestock. Marshall Silt Loam is found in southwestern Limn County, southeastern Harrison County, and northeastern Davless County in Missourl, and in the western counties of the Iovs section. 18 It is rated as good crop land in the classification by Lanpher.

Land in Missourl has been divided into three general clssses on the basls of 1 ts productivity and desirability for agricultural use.

16 weller, op. e1t. pp. $38-40$.

${ }^{27}$ Ibide, pp. 43-46.

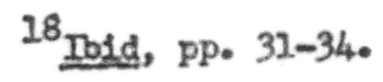


The areas that fall in each class are shown in F1gure 5. The cropland Is separated into good, average, and below average grades. Areas not adtable for cultivation are shown as pasture land.

Sharpsburg solls have developed on loessial material under grass regetation. They occur on upland slopes of two to twelve per cent in association with Winterset solls. The principal problem of Sharpsburg is control of erosion. Winterset solls occur on broad, Nat ridgetops. They are moderately slow to slowly permeable, and drainage inprovement 1s usually necessary for best crop ylelds. 19

Halg solls occur in association with Shalby and Grundy on the upIsnd pats in Southern Iow. Grundy is found on the two to seven per cent alopes adjacent to the Haig Nats. Drainage is the major problem on the Haig soils, and erosion control on the Grundy.

Edina soils occur on flat ridgetops in association with Shelby and Seymour. NI three have been developed on loess material under grass vegetation. Seymour solls occupy upland slopes with two to seven per cent grade. Sheet erosion is difficult to control on the Seymour. Drainage and maintainance of fertility are major problems on the Edina solls. 20

Wellen Solls occur on two to ten per cent upland slopes in

${ }^{19}$ Soil Conservation Service, Onited States Department of Agriculture, in cooperation with the Iow Agricultural Bxperiment Station, Briaf Description of Soll Units for Soll Survey in Iow Soll Conservation Districts, Ames, Iow, June 1956, pages 4, 39.

${ }^{20}$ Io1d, pages $4,38,22$. 
Southeastern Iowa. Ifindley is usually found associated with Wellen and Minton solls. All three series have developed on glacial till under forest vegetation. 21

\section{Qimate}

Average anmual rainfall in the area ranges from thirty-two to thirtymeren inches. 22 June is normally the wettest month.

The dniman length of growing seeson in the northwestern pert of the ares is 160 days. 23 The minimim length of growing sesson in the southern part is approximately 170 days.

The normal annual temperature is approximately fiftymone degrees. 24 The average crop seeson teapreature, April to September, 18 approximately sixty-seven degrees. The mean date of the last twentymed ght degree freeze in the spring is April 5, and the first twenty-eight degree freeze in the fall is October 20.25

Iocallzed spots in the twenty-nine county aree were drought sections during the 1953-55 three-year period. Data are not available to show the effects of these drought conditions, but they could have

21

Ib1d, pages 9, 10, 18.

22 Reed, Charles D., Temerature Noreals, (In cooperation vith Iowa Depertment of Agriculture, 1944. ) Page 155.

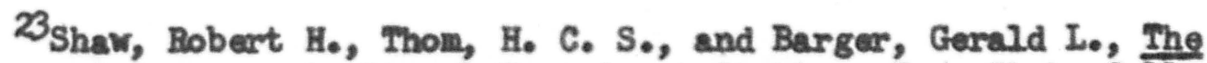
Ginate of Iors, Agricultural Bxperiment Station, Iow State College, Spectal Report Number 8, August 1954, page 24.

24 Reed, ㅇp. et.t., page 155.

${ }^{25}$ Shaw, 오. 소t., pages 18,2 . 
been the jor factor in deteruining income for a number of beginning farmers in one or more of the three years. For those people who had one or more bed years, the rate of espltal accumulation mag have been lower than could be expected for a long-time average or during three good years. It is doubtful, however, if the average farm income throughout the area was mach below wat normally could be expected. Number, Size, and Value of Farms in the Area

The number of farms has been decreasing in the twentymine county area. The fifteen count1es in K1ssourl had 26,169 farms in 1950. In 1954 the number had deoreased to 22,864 , a decline of 12.73 per cent. The fourteen counties in Iow had 23,092 farms in 1950. In 1954 the number had decreased to 21,185 . This was an 8.25 per cent decrease as show in Table I. The total number of farms in the twentymine county ares decressed 5,212, or 10.58 per cent between 1949 and 1954.

During the 1949-54 five-year period, the size of farm in the area Incressed. The Milsourl area had a median of 178.5 acres in 1949, ac compared to 201.5 in 1954. The Iova area had a median of 177.3 acres in 1949 and 191.2 acres in 1954 (Table II).

The average value of land and buildings per farm also increased during the five-jear period. The median value per farm in the Missouri area in 2949 wa $\$ 1,37$, as compared with $\$ 15,154$ in 1954 . As shom in Table II, In the Iows counties it rose from $\$ \mu_{4}, 13$ in 1949 to $\$ 18,039$ in 1954.

The median value of land and buildings per acre in the Missourl ares incressed from $\$ 57.95$ in 1949 to $\$ 70.19$ in 1954. In Iove it 
TABLE I

Number of Farms in Fifteen Northern Missourl and Fourteen Southern Iowa Count1es, 1950-1954.

\begin{tabular}{|c|c|c|}
\hline \multirow[b]{2}{*}{ Count1es } & \multicolumn{2}{|c|}{ Number of Farms } \\
\hline & 1950 & 1954 \\
\hline $\begin{array}{l}\text { Hessourl: } \\
\text { Adair } \\
\text { Daviess } \\
\text { Gentry } \\
\text { Grundy } \\
\text { Harrlson } \\
\text { Knox } \\
\text { Linn } \\
\text { Macon } \\
\text { Mercer } \\
\text { Putnam } \\
\text { Schuyler } \\
\text { Scotland } \\
\text { Shelby } \\
\text { Sullivan } \\
\text { Worth }\end{array}$ & $\begin{array}{l}1,926 \\
2,108 \\
1,705 \\
1,569 \\
2,513 \\
1,392 \\
1,951 \\
2,802 \\
1,476 \\
1,726 \\
1,018 \\
1,356 \\
1,644 \\
2,077 \\
906 \\
\end{array}$ & $\begin{array}{r}1,721 \\
1,889 \\
1,491 \\
1,420 \\
2,227 \\
1,172 \\
1,702 \\
2,381 \\
1,282 \\
1,417 \\
903 \\
1,172 \\
1,466 \\
1,881 \\
740 \\
\end{array}$ \\
\hline Total & 26,169 & 22,864 \\
\hline $\begin{array}{l}\text { Iowa: } \\
\text { Adams } \\
\text { Appanoose } \\
\text { Clarke } \\
\text { Davls } \\
\text { Decatur } \\
\text { Jefferson } \\
\text { Lucas } \\
\text { Monroe } \\
\text { Ringgold } \\
\text { Taylor } \\
\text { Union } \\
\text { Van Buren } \\
\text { Wapello } \\
\text { Wayne }\end{array}$ & $\begin{array}{l}1,512 \\
1,834 \\
1,387 \\
1,682 \\
1,744 \\
1,687 \\
1,482 \\
1,416 \\
1,670 \\
2,032 \\
1,458 \\
1,666 \\
1,794 \\
1,728 \\
\end{array}$ & $\begin{array}{l}1,355 \\
1,692 \\
1,260 \\
1,535 \\
1,561 \\
1,601 \\
1,345 \\
1,317 \\
1,544 \\
1,839 \\
1,376 \\
1,532 \\
1,610 \\
1,618 \\
\end{array}$ \\
\hline $\begin{array}{l}\text { Total } \\
\text { Total Change } \\
\text { Per Cent Change }\end{array}$ & $\overline{23,092}$ & $\begin{array}{l}21,185 \\
-5,212 \\
-10.58\end{array}$ \\
\hline
\end{tabular}

Source: 1954 Census of Agriculture - Missouri and Iow, United States Source: 1954 Census of Agriculture 
TABLE II

Average Size of Farm and Value of Iand and Bulldings in Fifteen Northerm Wissouri and Fourteen Southern Iove Count1es, 1950-1954.

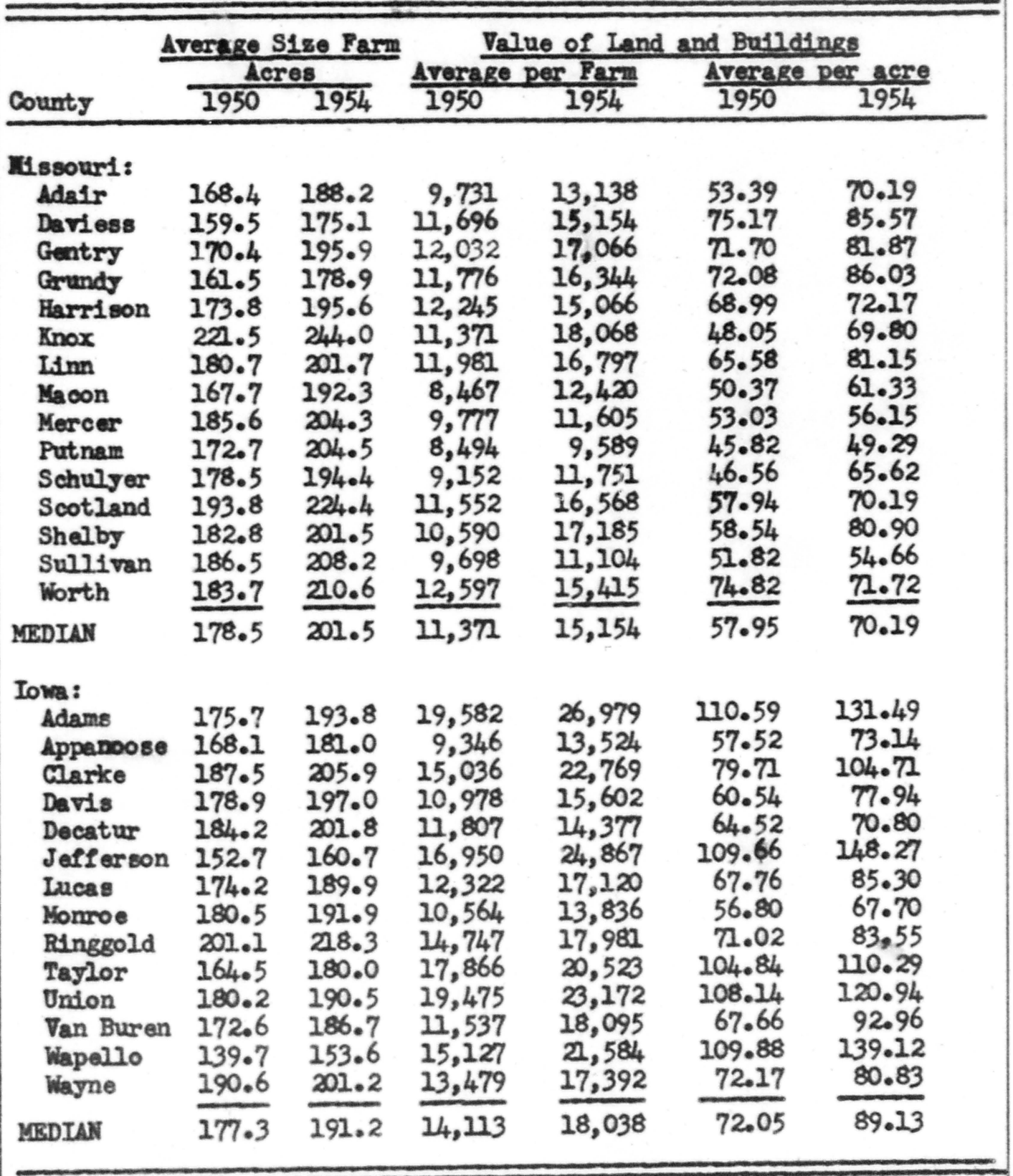

Source: 1954 Census of Agriculture - Missour1 and Iova, United States Department of Commerce, Bureau of the Census. 
rose from $\$ 72.05$ in 1949 to $\$ 89.13$ in 1954.

Number of Commercial Fares and Acres of Grop Iand Harvested

The number of commercial farms decressed in the twenty-nine county area from 1949 to 1954, as shoven in Table III. However, the number in Class I, CLass II and Class III increased. Commercial farms are divided Into six groups on the basis of the total value of all farm products sold, 26 as follows:

Mass I
Mlass II
Mass III
Mass IV
Mass V
MLas VI

$\$ 25,000$ or more
10,000 to 24,999
5,000 to 9,999
2,500 to 4,999
1,200 to 2,499
250 to $1,199$.

The number selling the largest amounts of farm products inereased as the total number decreased.

The number of farms harvesting over 100 acres of crops increased from 1949 to 1954. During the same perlod, the number of farms harvesting less then 100 acres decrased (Table III). Tenure Conditions

The trend in the ares has been toward farm enlargement by renting additional land. The number of full overs and tenants decressed during the 1ive-year period 1949-1954, but the number of part oveners increased. There was a decresse of 3,033 full owners and 1,877 tenants. The part owners increased by 552, as shown in Table IV.

26united States Bureau of the Census, United States Census of Apriculture: 1954, Missouri, Volume 1, Counties apd State Beonondc Areas, part 10, United States Government Printing Offlce, Washington, D. C., 1956. 
Table III

Number of Commercial Farms and Acres of Crop Land Harvested in Fifteen Northern M1ssourl and Fourteen Southern Iow Count1es, 1949-1954.

\begin{tabular}{|c|c|c|c|c|c|c|}
\hline \multirow[b]{2}{*}{ Conmercial Farms } & \multicolumn{2}{|c|}{ Mrssourd } & \multicolumn{2}{|c|}{ Iore } & \multicolumn{2}{|c|}{ Total } \\
\hline & 1950 & 1954 & 1950 & 1954 & 1950 & 1954 \\
\hline $\begin{array}{l}\text { CLass I } \\
\text { Class II } \\
\text { GLas III } \\
\text { CLass IV } \\
\text { CLass } \\
\text { CLass VI }\end{array}$ & $\begin{array}{r}166 \\
1,180 \\
3,754 \\
6,674 \\
6,110 \\
3,664 \\
\end{array}$ & $\begin{array}{r}203 \\
1,593 \\
4,326 \\
5,308 \\
4,588 \\
2,923 \\
\end{array}$ & $\begin{array}{r}206 \\
1,823 \\
5,516 \\
6,132 \\
4,100 \\
2,206 \\
\end{array}$ & $\begin{array}{r}313 \\
2,133 \\
5,012 \\
5,542 \\
3,700 \\
1,665 \\
\end{array}$ & $\begin{array}{r}372 \\
3,003 \\
9,270 \\
12,806 \\
10,210 \\
5,870 \\
\end{array}$ & $\begin{array}{r}516 \\
3,726 \\
9,338 \\
10,850 \\
8,288 \\
4,588 \\
\end{array}$ \\
\hline Total & 21,548 & 18,941 & 19,983 & 18,365 & 42,531 & 36,306 \\
\hline $\begin{array}{l}\text { Change: } \\
\text { Number } \\
\text { Percent }\end{array}$ & & $\begin{array}{l}-2,607 \\
-12.10\end{array}$ & & $\begin{array}{l}-1,618 \\
-8.10\end{array}$ & & $\begin{array}{l}-4,225 \\
-10.17\end{array}$ \\
\hline $\begin{array}{l}\text { Acres of Grop } \\
\text { Iand Harrested }\end{array}$ & 1949 & 1254 & 1942 & 2954 & 1249 & 1954 \\
\hline $1-9$ & 1,622 & 1,247 & 1,263 & 966 & 2,885 & 2,213 \\
\hline $10-19$ & 2,053 & 1,497 & 1,131 & 921 & 3,184 & 2,408 \\
\hline $20-29$ & 2,163 & 1,450 & 1,27 & 994 & 3,434 & $2,4,44$ \\
\hline $30-49$ & 4,207 & 2,991 & 2,791 & 2,377 & 6,998 & 5,368 \\
\hline $50-99$ & 7,143 & 5,868 & 7,015 & 5,951 & 14,158 & 11,819 \\
\hline $100-199$ & 4,685 & 5,184 & 6,048 & 6,230 & 10,733 & 11,424 \\
\hline Over 200 & 1,324 & 1,937 & 1,384 & 1,679 & 2,708 & 3,616 \\
\hline
\end{tabular}

Source: 1954 Census of Agrleulture - Missourl and Iova, United States Department of Commerce, Bureau of the Census. 
TABLE IV

Temure Conditions in FIfteen Northern Missourl and Fourteen Southern Iow Count1es, 1950-1954.

\begin{tabular}{|c|c|c|c|c|c|c|}
\hline \multirow[b]{2}{*}{ Temure } & \multicolumn{2}{|c|}{ Missouri } & \multicolumn{2}{|c|}{ Iove } & \multicolumn{2}{|c|}{ Total } \\
\hline & 1950 & 1954 & 1950 & 1954 & 1950 & 1954 \\
\hline Ful Owner & 15,209 & 13,566 & 13,388 & 11,998 & 28,597 & 25,564 \\
\hline Part Omer & 5,356 & 5,656 & $4, \infty 02$ & 4,253 & 9,357 & 9,909 \\
\hline All Tenant & 5,123 & 4,053 & 5,686 & 4,888 & 10,818 & 8,941 \\
\hline Percent of Tenancy & 19.97 & 17.41 & 24.64 & 23.12 & 22.18 & 20.13 \\
\hline Cash Tenants & 950 & 543 & 760 & 497 & 1,720 & 1,040 \\
\hline Share-Cash & 2,044 & 1,503 & 2,817 & 2,358 & 4,861 & 3,861 \\
\hline Share and Cropper & 1,504 & 1,434 & 1,548 & 1,619 & 3,052 & 3,053 \\
\hline $\begin{array}{l}\text { Share-crop and } \\
\text { croppers }\end{array}$ & 750 & 646 & 381 & 464 & 1,131 & 1,110 \\
\hline LAvestock share & 754 & 788 & 1,167 & 1,155 & 1,921 & 1,943 \\
\hline Other & 634 & 573 & 561 & 424 & 1,195 & 987 \\
\hline
\end{tabular}

Source: 1954 Census of Agrl culture - Missourl and Iova, United States Department of Conmerce, Bureau of the Census. 
The number of cash, share and cash tenants decreased, but the number of share cropper tenants stayed the same, (Table IV). Amount of off Farm Work in the Ares

The number of farm operators with nonfarm income greater than the value of farm produce sold varied between the two states. In 1949 , the Missouri area had 4,365 farm operators with nonfarm incone greater than the value of farm products sold. In 1954, 3,897 operators had more Income from off-farm work than from the farm. This is a decrease of 10.72 per cent. In the Iove area, 3,166 operators received more than one-half of their income from off-farm sources. By 1954, the number had incressed to 3,4 - a gain of 7.74 per cent.

The number of farmers in the Missours count1es who were voring off their farms in 1949 mas 7,925. In 1954 the number had increased to 8,005 - a gatn of 1.01 per cent. In the Iove ares, 7,208 operators wee working off their farme in 1949. In 1954 the number had risen to 8,385 - an incresse of 16.33 per cent. In $1949,3,478$ K1ssour1 operstors were wording off their farms 100 days or more. In 1954 the number had decilined to 3,421. Thls nas a 1.93 per cent decrease. In $1949,3,169$ Iowa operators worked off thedr farms 100 or more days. By 1954 the number had Increased to 3,562. This wa a 12.4 per cent Increase (Table V). The data show that off-farm eaployment opportunit1es have been increasing more rapidly in the fourteen Iow counties than in the fifteen Missourl counties.

Chapter III contains an analysis of the farm businesses of the 1953 beginning farmers. It is based upon tenure status when the men 


\section{TABIS V}

Off Farm Work by Farm Operators in Fifteen Northern Missourd and Fourteen Southern Iowa Count1es, 1949-1954.

\begin{tabular}{|c|c|c|c|}
\hline & Missourt & Iores & Total \\
\hline Off Farm Work & $1949 \quad 1954$ & $1949 \quad 1954$ & $1949 \quad 1954$ \\
\hline
\end{tabular}

Farm Operators:

With other income of fandly exceeding value

$\begin{array}{lllllll}\text { of farm produce sold } & 4,365 & 3,897 & 3,166 & 3,411 & 7,531 & 7,308\end{array}$

Number reported working off farm

$$
\begin{array}{llllll}
7,925 & 8,005 & 7,208 & 8,385 & 15,133 & 16,390
\end{array}
$$

Number working off farm 100 days or more $3,478 \quad 3,411 \quad 3,169$ 3,562 6,647 6,973

Change $-67$ $+393$ $+326$

Percent change $-1.93$ $+12.4$ $+4.92$

Source: 1954 Census of Agr1culture - Missourl and Iowa, Unfted States Department of Commerce, Bureau of the Census. 
started farming for the first time. Particular attention is given to size of business, family assistance, credit conditions, income from off-farm work, and changes in net worth. 
CHAPTER III

FINDINGS

PERTINENT FACTS ABOUT BEGDNING FARMISRS

Background of Beginning Farmers

One hundred fifty-tivo of the operators who began farming in 1953 In 29 counties of North Central Missourl and South Central Iowa were st1ll farming at the close of 1955. The findings discussed here deal wth the experiences of this group. As show in Table VI, 84.9 per cent of these men had previous farm experlence. Nembers of the entire group had completed an average of 11.7 years of sebool. Seventy-eight per cent were high school graduates. Seven had finished college. Thirty-8dx per cent of the men had $4-H$ Glub experlence, and 51 per cent had taken Vocational Agriculture in high school. The average age at the time they started farming ws 25.4 years. Seventy-seven per cent were married at the time they began faming. Ninety-five per cent of the men were farm reared. Seventy-seven per cent were veterans, and 18 per cent attended Inst1tutionsl-On-Farm Training clssses in 1953.

Twenty-three per cent of the group recelved fandly help valued at P1ve hundred dollars or more in 1953. Bleven per cent had recelved flve hundred dollars or more of fandly help prior to 1953.

The most Important source of land farmed by 48 per cent of the men was thedr parents' farm. Other relatives' farms ws the most important source for 4.6 per cent of the men. 
TABLE VI

Pertinent Facts About 1953 Beginning Farmers in Fifteen Northern Missour1 and Fourteen Southern Iow Counties, 1953.

\section{Farm Operators:}

Number starting to farm in 1953 ........... 152

Average age when started farming ........... 25.4

Average number of years of formal education ....... 11.7

Percentage of high school graduates . . . . . . . . 77.6

Percentage of college graduates . . . . . . . . . 4.6

Percentage vith Vocational Agoiculture

training in high school ............. 51.3

Percentage that had been 4-H Club nembers ........ 36.2

Percentage married when started farming ......... 77.0

Percentage with farm experience prior to starting to farm .......................... 84.9

Percentage of veterans ............. 67.1

Percentage of veterans with On-the-Farm

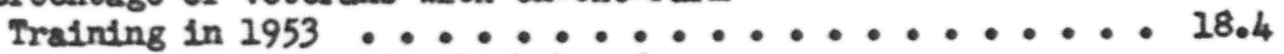

Percentage recelving famfly help of

$\$ 500$ or more:

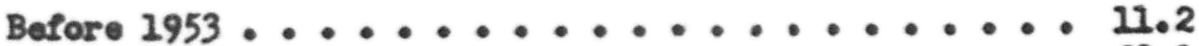

During $1953 \ldots 23.0$

Percentage whose most important source of land

farmed was parents' farm ............... 48.0

Percentage wose most important source of land

farmed was other relatives' farm ........... 4.6

Percentage of operators who were farm reared ....... 95.4 
PROCEDURE IN ANALYSIS

For purposes of analysis, the records were divided according to type of tenure with wich the man began farming. Six basic tenure groups were found. The number of men starting in each group were as follows: (1) owner-operator, 13; (2) part-owner, 17; (3) cash tenant, 6; (4) crop share tenant, 32; (5) crop-share-cash, 37; and (6) livestock-share tenant, 47.

An analysis of the firm based on type of tenure was made for 1953. A simlar analysis composed of the original group in 1953 was made of the 1955 businesses of each group. Comparisons were made among the various tenure groups. The major factors consiciered were change in net worth, change in total assets under the operator's control, size of business, off-farm work, family help, tenure status, credit, and indebtedness.

\section{SOURCES OF STARTING CAPITAL}

Funds Supplies by the Operator

One hundred four of the 116 married operators furnished most of the funds with wich they started farming. Six wives furnished the major share of funds. One couple thought each had contributed equally to the beginning capital. Five couples said their beglnning funds ware nil. They were able to find a land ower who would supply the land and equipment. FIfty operators reported earnings from work on their parents' farm was the major source of capital with which they started farming (Table VII). Sarings from the income earned while in 


\begin{tabular}{|c|c|c|c|c|c|c|c|}
\hline \multicolumn{8}{|c|}{$\begin{array}{c}\text { TABIS VII } \\
\text { Major Source of Beginning Funds of } 1953 \text { Beginning Farmers in Fifteen Northern Missourd and Fourteen } \\
\text { Southern Iove Counties, According to Type of Tenure In 1953. } \\
\text { (Numb receiving funds from soch source.) }\end{array}$} \\
\hline Source & $\begin{array}{l}\text { Owner- } \\
\text { operator }\end{array}$ & $\begin{array}{l}\text { Part- } \\
\text { ormer }\end{array}$ & Cash & $\begin{array}{l}\text { Crop } \\
\text { share }\end{array}$ & $\begin{array}{l}\text { Grop share } \\
\text { cash }\end{array}$ & $\begin{array}{c}\text { Livestock } \\
\text { share }\end{array}$ & Total \\
\hline None & & 1 & & 2 & 3 & 5 & 11 \\
\hline Parents' farm & 1 & 8 & 1 & ג & 13 & 16 & 50 \\
\hline Other farm work & 1 & 1 & 1 & & 2 & 5 & 10 \\
\hline Armed services & 5 & 4 & 3 & 12 & 3 & 13 & 40 \\
\hline Education & & & & 1 & 1 & & 2 \\
\hline Bookkeeping and secretarial & & 1 & & 1 & 1 & & 3 \\
\hline Public service (non-ekdlled) & & 1 & & & 1 & & 2 \\
\hline Public service (skilled) & 2 & 1 & 1 & & 1 & 1 & 6 \\
\hline Industrial (non-sikilled) & 1 & & & 1 & 2 & & 4 \\
\hline Industrial (skdlled) & 3 & & & 4 & 9 & 7 & 23 \\
\hline Private business & & - & - & 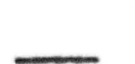 & 1 & - & 1 \\
\hline TOTAL & 13 & 17 & 6 & 32 & 37 & 47 & 152 \\
\hline
\end{tabular}


the armed services was considered the major source by forty men. Money from addled industrial labor was the major source for twentythree men. Income from work as a hired farm hand enabled ten men to get started in farming.

The major source of capital used by tenants was savings while in the armed services, and wages while wording at skjlled industrial jobs. Thirty-eight per cent of the ovener operators got their start from savings in the armed services. The beginning funds for 47 per cent of the part-owners were obtalned from working on their parents' farms. Savings from armed service pay was the major source for 50 per cent of the cash tenants. Thirty-ight per cent of the crop share tenants reported that savings from armed service pay was the mor source of starting capital. However, 34 per cent consldered earnings from work on thelr parents' farms to be the major source. The major souree for 35 per cent of the wop share cash tenants was earnings from rork on their parents' farms. Twenty-four per cent considered earnings from skdiled Industrial labor to be the mojor source of their beginning funds. Thirty-four per cent of the livestock share tensnts reported earnings from work on their parents' farms to be the prinelpal source. Tumety-alght per cent considered savings from armed service pay to be the major source.

As shown in Table VII, elghtymo operators reported that they did not have a second major source of funds with which to start farming Twentymedx operators reported savings from armed service pay to be the second major source. Skdlled Industrial jobs was the second major source for ten operators. 
TABLE VIII

Second Major Source of Beginning Funds of 1953 Beginning Farmers in FIfteen Northern Mlisourl and Fourteen Southern Iow Counties, According to Type of Tenure in 1953.

\begin{tabular}{|c|c|c|c|c|c|c|c|}
\hline Source & $\begin{array}{l}\text { Ovener- } \\
\text { Operator }\end{array}$ & $\begin{array}{l}\text { Part- } \\
\text { Ovmer }\end{array}$ & Cash & $\begin{array}{l}\text { Grop } \\
\text { Share } \\
\end{array}$ & $\begin{array}{l}\text { Crop share } \\
\text { Cash }\end{array}$ & $\begin{array}{c}\text { If vestock } \\
\text { Share }\end{array}$ & Total \\
\hline None & 7 & 9 & 2 & 20 & 15 & 28 & 81. \\
\hline Parents' farm & & & & 1 & 3 & 1 & 5 \\
\hline Other farm work & 1 & & & 1 & & 1 & 3 \\
\hline Armed services & 1 & 4 & & 5 & 7 & 9 & 26 \\
\hline Bducation & & & & & 2 & & 2 \\
\hline Bookkeeping and secretarlal & & 1 & 1 & & 4 & 3 & 9 \\
\hline Public service (non-ekdlled) & & 1 & 1 & 1 & 1 & 1 & 5 \\
\hline Public service (skdlled) & 1 & 1 & 1 & 1 & & & 4 \\
\hline Industrial (non-skilled) & 2 & & 1 & & 3 & 1 & 7 \\
\hline Industrial (skilled) & 1 & 1 & & 3 & 2 & 3 & 10 \\
\hline Private business & - & - & - & - & - & - & 0 \\
\hline TOTAL & 13 & 17 & 6 & 32 & 37 & 47 & 152 \\
\hline
\end{tabular}


The sources of initial funds for most of the 1953 beginning farmers were Income from their parents' farms, the armed services, and offararm industrial labor. Very few men secured beginning funds from labor as hired farm hands. This is further evidence of the old concept of the agricultural ladder being replaced. The f1rst phase, work as a hired farm laborer, is being skdpped by beginning farmers.

\section{BORROWED FUNDS}

\section{Non-Real Estate Credst}

Twenty-five per cent of the men did not use non-real estate aredit In 1953. As show in Table IX, 14 operators recedved 166 loans that averaged $\$ 1,44$ each. Grop-sharemesh tenents borrowed an average of $\$ 1,854$. This was the largest amount borrowed by any tenure group. Cash tenants borrowed the anallest amounts, which areraged $\$ 817$ per man. Grop-aharemash tenants had the longest term on their loans. It a varaged 13.9 months. Grop share tenants loans were for the shortest term, whth an average of 5.2 months. The average term for the entire group was 7.9 months. The major purposes of the loans were operating expenses, livestock purchases, and nochinery purchases. A small number of consumption and real estate improvement loans were obtained.

Source, interest rate and term.-Conmercial banks were the major source of non-real estate credit, as shown in Table $X$. Seventymight of the 166 loans ware obtained from this source. The average interest rate 6.5 per cent, and the average term 8.42 months. The average amount loaned by commercial banks was $\$ 1,291$. The average amount per loan from all sources wa $\$ 1,320$. 


\section{TABLE IX}

Average Interest Rates, Terms, and Amount of Non-Real Estate Credit Used by Beginning Farmers During 1953 in FIfteen Northern Missourl and Fourteen Southern Iow Counties, by Type of Tenure.

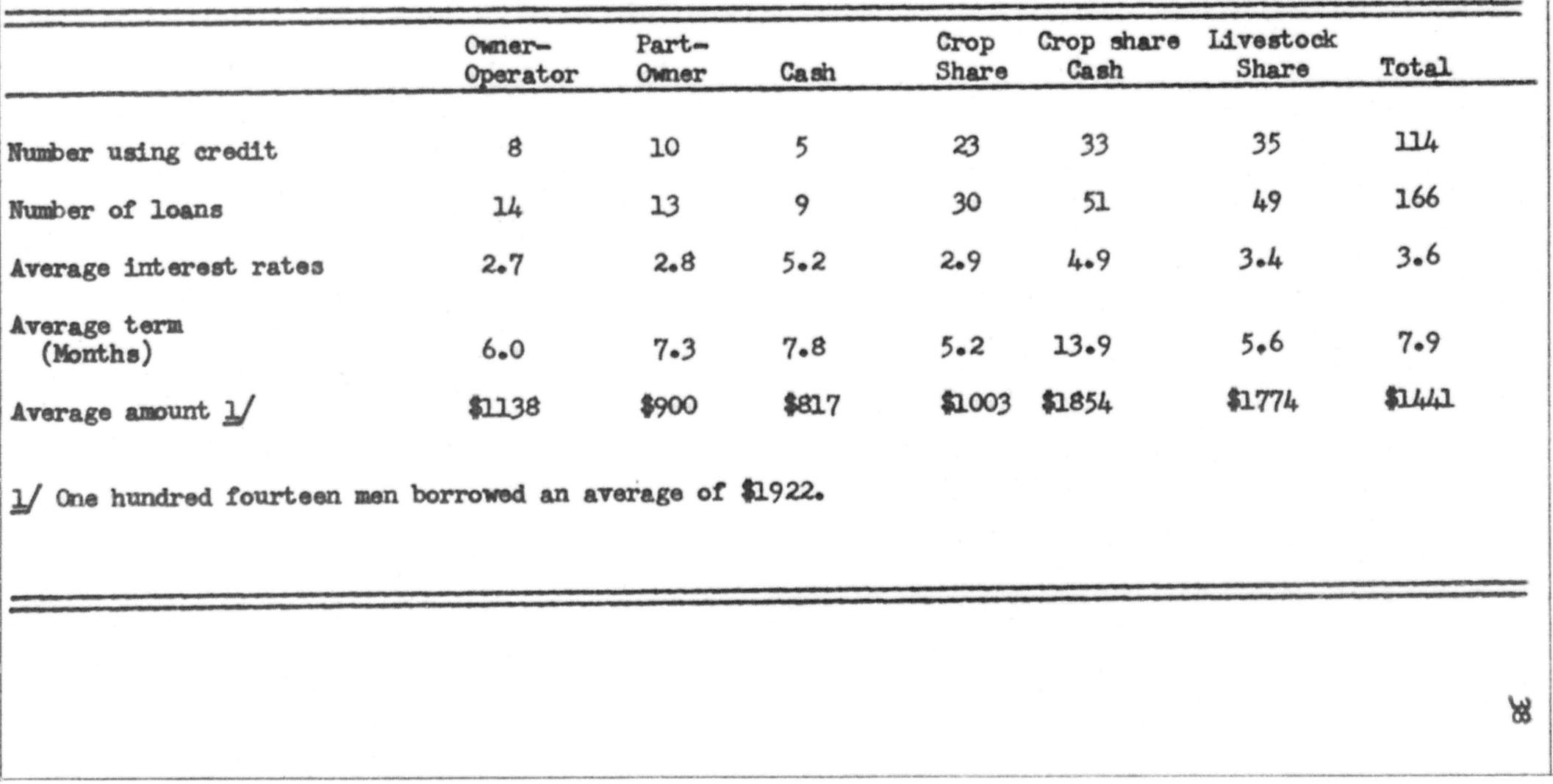


TABLE X

Average Interest Rates, Term, and Amount of Non-Real Bstate Credit, by Source, Used by Beginning Farmers During 1953 in F1fteen Northern Missourl and Fourteen Southern Iove Count1es.

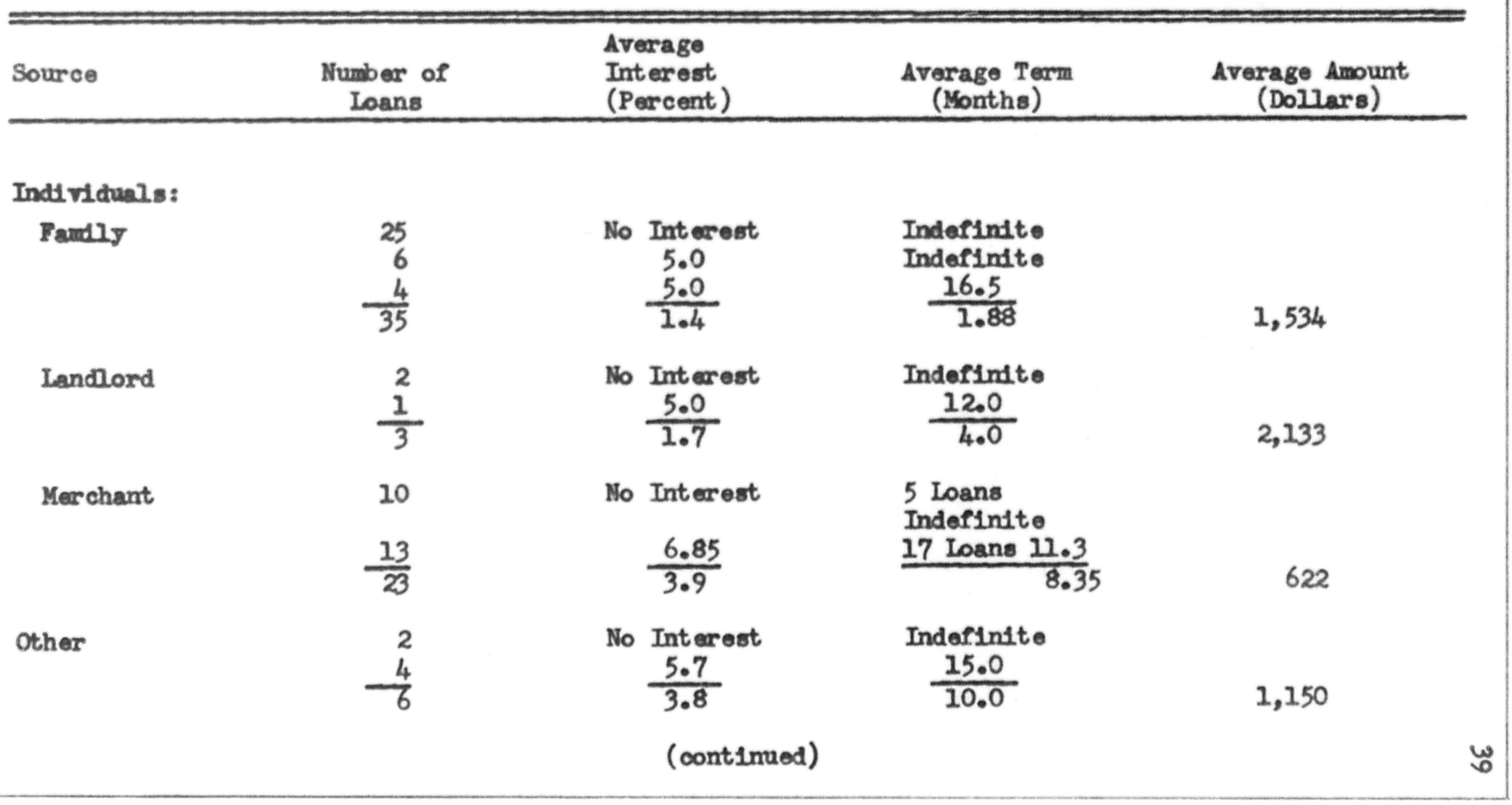


TABLS $x$, continued.

Average Interest Rates, Term, and Amount of Non-Real Estate Credit, by Source, Used by Beglnning Farmers During 1953 in F1fteen Northern Mlsourl and Fourteen Southern Iove Counties.

\begin{tabular}{|c|c|c|c|c|}
\hline Source & $\begin{array}{c}\text { Number of } \\
\text { Ioans }\end{array}$ & $\begin{array}{l}\text { Average } \\
\text { Interest } \\
\text { (Percent) }\end{array}$ & $\begin{array}{c}\text { Average Term } \\
\text { (Honths) }\end{array}$ & $\begin{array}{l}\text { Average Amount } \\
\text { (Dollars) }\end{array}$ \\
\hline $\begin{array}{l}\text { Government : } \\
\text { PCA } \\
\text { FHA } \\
\text { CCC }\end{array}$ & $\begin{array}{l}4 \\
8 \\
3\end{array}$ & $\begin{array}{l}5.25 \\
4.87 \\
4.66\end{array}$ & $\begin{array}{l}12.00 \\
44.25 \\
12.00\end{array}$ & $\begin{array}{l}1,550 \\
2,913 \\
1,067\end{array}$ \\
\hline $\begin{array}{l}\text { Commercial: } \\
\text { Bank } \\
\text { Loan Company }\end{array}$ & $\begin{array}{r}78 \\
6\end{array}$ & $\begin{array}{l}6.50 \\
8.66\end{array}$ & $\begin{array}{r}8.42 \\
18.00\end{array}$ & $\begin{array}{r}1,291 \\
733\end{array}$ \\
\hline All Sources & 166 & 3.3 & 7.2 & 1,320 \\
\hline
\end{tabular}


Family loans ware the second largest source, the total number being 35. Twenty-f1ve were whout interest and for indefinite periods of t1me. S1x bore a 5.0 per cent 1nterest charge, whth an average term of 16.5 months. The average amount borrowed from the fandly was $\$ 1,534$.

Merchants were the third largest source of eredit. Twanty-three loans, averaging \$622, ware obtalned from retallers. Ten loans had no Interest charge. F1ve of these were for indefindte perlods of time. Thirteen loans carrled an average of 6.85 per cent Interest. Seventeen. loans had an average term of 12.3 months.

Farmers Home Adinintration was the fourth major source of credit. This agency loaned to 8 of the beginning farmers. The loans averaged 4.87 per cent 1nterest, wh a term of 44.25 months. The average amount was \$2,913.

Security. - Forty-two of the 166 loans were obtained wdth the oper ator putting up no securelty. Nost loans of this type were made by family nembers. A chattel mortgage on the 1tem purchased wh the money furntshed security for 31 loans. A chattel mortgage on an 1tem already owned by the borrower furntshed securlty for 21 loans. Flghteen loans were secured by having a famlly member cosign the note. Signatures of non-relat1ves and real estate mortgages were security for a mall number of loans.

\section{Real Bstate Gredit.}

The average value of land that had been acquitred by 23 of the men prior to 1953 as $\$ 6$ 17. Four of them had 1nherited the land. One 
did not farm the land or receive any income from it during the study period. FIve men had made cash purchases.

Thirteen credit buyers in the overship group had made average down payments of $\$ 2,546$. One credit buyer purchased his land on an installment contract and made no down payment. The average interest rate was 4.57 per cent. Three men had indefinite term loans. The average length for 11 of the men wa 17.2 years. Seven of the 14 eredit buyers had flexible payment plans which permitted the buyer to adjust the size of his payment in accordance idth his income. The remaining 7 had average payments of $\$ 386$ per year.

Real estate purchsses.-Ten men purchased land in 1953. Seven loans were secured by a mortgage on the farm real estate. Three men in Iowa used purchase contracts.

Desire for farm ovenership was the major reason for 5 land purchases. Two men had to buy in order to obtain a farm. One man bought to enlarge his present farm. Uncertainty of tenure on rented land was the major reason for 2 purchases.

Four men purchased land from a non-farm person vithin 50 milles of the farm. Three operators acquired land from retired farmers, while 2 men bought land from active farmers who were ready to retire or to enter another occupation.

Four owner-operators, IIve part-overs, and one share cash tenant purchased land in 1953. The average value of the acquired land, by tenure groups, was: (1) ovener-operators, \$5,875; (2) part-omers, \$1. 200; and (3) sharemesh tenants, $\$ 10,400$. Two omer-operators 
and two part-owners did not make down payments. Two omer-operators made average down payments of $\$ 900$. The average for part-owners was $\$ 5,500$, but one part-oumer paid $\$ 12,000$ down. The money was a gift from his family. The share cash tenant made a \$5,200 down payment. One owner-operator and one part-owmer were not charged interest. They purchased their land from members of the family. The average rate for other purchasers was 5.5 per cent.

Two owner-operators obtained a loan of indefinite length. The average term for the other men wa 8.4 years. Seven men had flexible annual payments. Three men had average annual payments of $\$ 733$. Total Amount Borrowed.

The average amount of money borrowed by the various tenure groups was as follows: (1) owner-operators, \$5,992; (2) part-owners, \$5, 288; (3) cash tenants, \$817; (4) crop-share tenants, \$1,003; (5) crop-sharecash renters, \$1,995; and (6) I1vestock-share tenants, \$1,849. The average per man for all groups was $\$ 2,319$. Those who used real estate credit borrowed the following amounts secured by llens on land and improvement s: (1) ower-operators, \$3,854; (2) part-owners, \$4,388; (3) cash tenants, none; (4) crop-share renters, none; (5) crop-sharecash, \$141; and (6) Livestock-share tenants, \$74. The average per man for those using real estate credit was $\$ 743$.

Family Assistance

One hundred thirty-eight gifts, averaging $\$ 769$, were received by 88 operators. As shown in Table XI, livestock share tenants received 50 gifts. This was the largest number received by any tenure group. 


\section{TABLE XI}

Type and Amount of Family Help Recelved By Beginning Farmers During 1953 in Fifteen Northern Missourl and Fourteen Southern Iow Counties, by Tenure Groups.

\begin{tabular}{|c|c|c|c|c|c|c|c|c|c|c|c|c|}
\hline \multirow[b]{2}{*}{ Type of Gafts } & \multicolumn{2}{|r|}{ Owner } & \multicolumn{2}{|c|}{ Part-Ovmer } & \multicolumn{2}{|r|}{ Cash } & \multicolumn{2}{|c|}{ Crop-Share } & \multicolumn{2}{|c|}{$\begin{array}{c}\text { Crop } \\
\text { Shareasas } \\
\end{array}$} & \multicolumn{2}{|c|}{$\begin{array}{l}\text { Livestock } \\
\text { Share }\end{array}$} \\
\hline & No. & $\begin{array}{l}\text { Average } \\
\text { amount }\end{array}$ & No. & $\begin{array}{l}\text { Average } \\
\text { amount }\end{array}$ & No. & $\begin{array}{l}\text { Average } \\
\text { amount }\end{array}$ & No. & $\begin{array}{l}\text { Average } \\
\text { amount }\end{array}$ & No. & $\begin{array}{l}\text { Aversge } \\
\text { amount }\end{array}$ & No. & $\begin{array}{l}\text { Average } \\
\text { amount }\end{array}$ \\
\hline Cash & - & - & 1 & $\$ 2500$ & - & - & 3 & $\$ 300$ & - & - & - & $\$ 1000$ \\
\hline Livestock & 1 & $\$ 100$ & 2 & 300 & 3 & $\$ 267$ & 2 & 100 & 4 & $\$ 600$ & $u_{4}$ & 557 \\
\hline Machinery & - & - & - & - & 1 & 100 & - & - & - & - & 5 & 1000 \\
\hline Feed, seed, etc. & 1 & 100 & 3 & 267 & 3 & 800 & 1 & 1100 & 1 & 100 & 6 & 767 \\
\hline
\end{tabular}

Use of family

machinery and unpeid family labor

Farm real estate

Household goods

$2 \quad 150$

Total number gafts and average amount

$-\quad-$

$-$

$12000 \quad-$

$\begin{array}{llllllllllll}4 & \$ 125 & 1_{4} & \$ 1257 & 8 & \$ 450 & 33 & \$ 312 & 29 & \$ 303 & 50 & \$ 538\end{array}$


Owner-operators recelved the mallest number of gifts. The major types ware use of fandly machinery and unpaid family labor.

Certain kinds of family assistance cannot be assigned a money value. Renting the family farm, help from the fandly in renting land in the communty, cosigning of notes, and advice in making management decislons are examples. These 1tems may be of greater value than the gifts listed in Table $\mathrm{XI}$.

It should be recognized, however, that advice and guidance from the fandly may be a hindrance rather than an aid in certain cases. Family pressure on young men to rent small, inefflcient farm units is an example of this type. Equity

The low equity position of each operator from whom data were obtained ws determined by using the following formula: Iow Net Worth. January 1.2953 Equity $=$ Net Worth, Jamuary 1, 1953 f Total Amount Borrowed in 1953 For example: Net worth January 1, $1953=\$ 6,000$.

Total amount borrowed in $1953=\$ 1,500$.

Then $\frac{\$ 6,000}{\$ 6,0007 \xi 1,500}=80$ percent, or the low equity position of The average low equity for each tenure group was as follows: (1) eropshare tenant, 80.9 per cent; (2) cash tenant, 80.0 per cant; (3) I1vestock-share tenant s, 77.6 per cent; (4) crop-share-cash, 73.2 per cent; (5) part-owner, 70.1 per cent; and (6) omer-perstor, 67.2 per cent. Real estate loans were the reason the owners and partmowers had the lowest average equity. 
Gredit Reruseis

Seven operators were refused credit in 1953. Four of them had one refusal, and 3 were refused 3 times. Six men vere refused because they had insufflcient security for the loan. The other men were rerused because the lender thought the purpose for wich the money was sought was too risky.

\section{THE FARM BUSINESS}

General farming is the dominant type in the ares. Only 2 operators did not hsve 11restock in 1953. Beef cattle, hogs, and dalry cattle were the major livestock enterprises, but a few farmers had major sheep or poultry enterprises along wdth their other livestock. Size of Buginess

As shown in Table XII, I1vestock-share tenants were on the largest farms. They had an average of 232 acres. Cash tenants were on the smallest farms, averaglng 100 acres. The average size of all farms was 196 acres.

Acres of exopland. including har and rotation pasture -Operators with crop-share-cash leases had the highest average acreage of cropland (125 acres). Livestock-share tenants followed closely udth an average of 123 acres. Cash tenants had the smallest number of acres, wh an average of 57. The entire group had an avarage of 112 acres, as shown in Table XIII.

Use of cropland.-As shown in Table XIV, the avarage number of acres in corn, wheat and soybeans in 1953 was 69 acres. Crop share 


\section{TABLE XII}

S1ze of Business in Terms of Total Acres Operated by Beginning Farmers in FIfteen Northern Missouri and Fourteen Southern Iow Counties During 1953, by Tenure Groups, (Number of Operators in Each Tenure Group)

\begin{tabular}{|c|c|c|c|c|c|c|c|}
\hline $\begin{array}{l}\text { Total } \\
\text { Acres } \\
\end{array}$ & Owner & $\begin{array}{l}\text { Part } \\
\text { Onener }\end{array}$ & Cash & $\begin{array}{l}\text { Crop } \\
\text { Share } \\
\end{array}$ & $\begin{array}{c}\text { Crop Share } \\
\text { Cash } \\
\end{array}$ & $\begin{array}{c}\text { Ifivestock } \\
\text { Share }\end{array}$ & Total \\
\hline $40-119.9$ & 3 & 2 & 4 & 10 & 3 & 5 & 27 \\
\hline $120-199.9$ & 8 & 5 & 2 & 13 & 19 & 18 & 05 \\
\hline $200-279.9$ & 1 & 5 & & 7 & 10 & 10 & 33 \\
\hline $280-359.9$ & 1 & 4 & & 1 & 4 & 7 & 17 \\
\hline $360-439.9$ & & 1 & & & & 2 & 3 \\
\hline $440-319.9$ & & & & & 1 & 4 & 3 \\
\hline $320-399.9$ & & & & 1 & & 1 & 2 \\
\hline Towal & 13 & 17 & 0 & 32 & 37 & 47 & $1>2$ \\
\hline $\begin{array}{l}\text { Average Size } \\
\text { (Acres) }\end{array}$ & 133 & 218 & 100 & 103 & 198 & 232 & 190 \\
\hline
\end{tabular}




\section{TARLS XII}

Sige of Business in Terms of Acres of Cropland Operated by Beginning Famers in Flfteen Northern Milsoum and Fourteen Southem Ion Count1es During 1933, by Tenure Groups (Number of Operators in each Tenure Group)

\begin{tabular}{|c|c|c|c|c|c|c|c|}
\hline $\begin{array}{l}\text { Aares of } \\
\text { Gropland }\end{array}$ & Orener & $\begin{array}{l}\text { Part } \\
\text { Ormor }\end{array}$ & Cash & $\begin{array}{l}\text { Grop } \\
\text { Share }\end{array}$ & $\begin{array}{l}\text { Crop Share } \\
\text { Cash }\end{array}$ & $\begin{array}{l}\text { Ifvestock } \\
\text { Share }\end{array}$ & Totel \\
\hline $0-29$ & & & 2 & & & & 2 \\
\hline $30-59$ & 5 & 3 & 2 & 3 & & 2 & 15 \\
\hline $60-89$ & 4 & 4 & & 7 & II & II & 37 \\
\hline $90-119$ & 3 & 1 & 1 & 10 & 9 & $u_{4}$ & 38 \\
\hline $120-149$ & & 0 & 1 & 0 & 8 & 7 & 28 \\
\hline $150-179$ & 1 & & & 3 & 3 & 0 & 13 \\
\hline $180-209$ & & 1 & & 2 & 4 & 2 & 9 \\
\hline $210-239$ & & 1 & & 1 & & 2 & 4 \\
\hline $240-209$ & & 1 & & & 1 & 1 & 3 \\
\hline 270 or Over & & & & & 1 & 2 & 3 \\
\hline Total & 13 & 17 & 0 & 32 & 37 & 47 & 122 \\
\hline $\begin{array}{l}\text { Average Acres } \\
\text { of Cropland }\end{array}$ & 72 & 110 & 57 & $10 \%$ & 125 & 223 & 112 \\
\hline
\end{tabular}




\section{TABIS XIV}

Size of Business in Terms of Acres of Corn, Wheat, and Soybeans Grovn by Beginning Farmers in Fifteen Northerm Nissouri and Fourteen Southern Iove Counties During 1953, by Tenure Groups (Number of Operam tors in Bach Tenure Group)

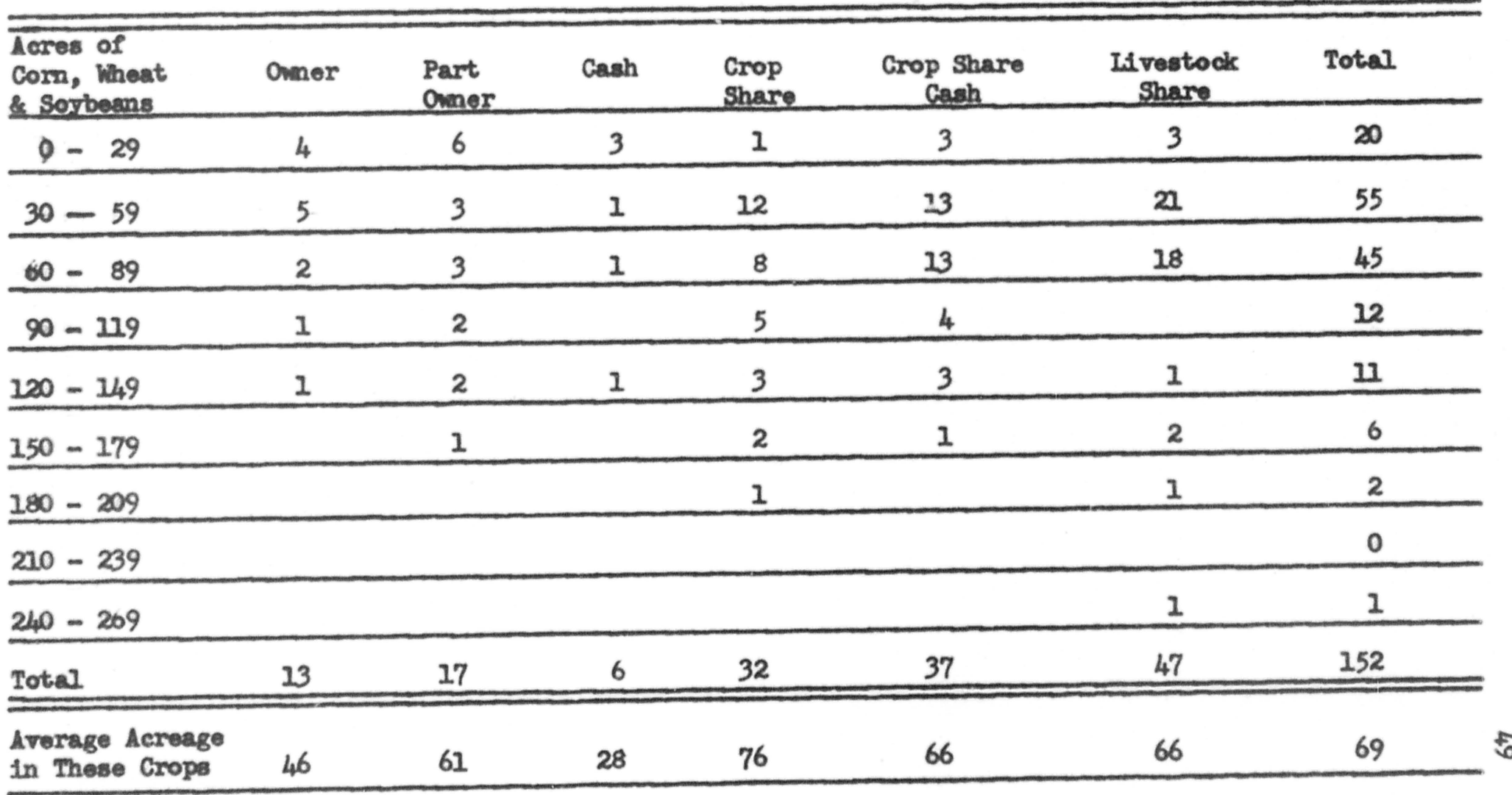


tenants had the largest average with 76 acres. The lowest was 28 acres on the farms of cash tenants.

Productive Man Work Units.-The size of business varied widely, as show by the productive man work units required to take care of the entexprises. Grop share tenants were required to spend 152 standard work days looking after their enterprises. They were less fwly employed than any other tenure group. Over-operators and cash tenants also were under employed, vdth 163 and 176 productive man work units respectively. The farm businesses of the livestock-share tenants called for 283 standard days of labor. Partwovers were second, with 240 . The average productive man work units for the entire group was 222.

The same order held for productive man work units per man ss held for total productive man work units, as shovn in Table XV. Thirty-four per cent of the operators were employed less than 200 days on the farmo In other words, they did not have a full work load.

Labor requirements were greater for livestock than for crops on the Livestock-share, csash, and over-operator farms. As shown in Table XVI, the labor required for dairy cattle was greater than for any other type of livestock on all farms except those operated under livestock-share lesses. Beef cattle took the largest amount of labor on the latter group of farms. Apparently dairy cattle were used by all tenure groups to provide a source of steady income.

As shown in Table XVII, the total months of labor avallable on the farms varied among the tenure groups. Fired labor, unpaid family 


\section{TABLE XV}

Size of Business Operated by Beginning Farmers in Fifteen Northern Nissourl and Fourteen Southern Iowa Cormties During 1953, in Terms of Productive Man Work Units, (Number of P.M.W.U. Required by Each Group)

\begin{tabular}{|c|c|c|c|c|c|c|}
\hline Item & Ormer & $\begin{array}{l}\text { Part } \\
\text { Onner }\end{array}$ & Cash & $\begin{array}{l}\text { Crop } \\
\text { Share } \\
\end{array}$ & $\begin{array}{c}\text { Crop Share } \\
\text { Cash } \\
\end{array}$ & $\begin{array}{c}\text { Ifrestock } \\
\text { Share }\end{array}$ \\
\hline Crops & 79 & 119 & 03 & 112 & 129 & 133 \\
\hline If restock & 84 & 116 & 113 & 40 & 96 & 150 \\
\hline Total & 163 & 235 & 176 & 152 & 225 & 283 \\
\hline Man equivalent & .992 & .98 & .917 & .959 & .98 & 1.08 \\
\hline 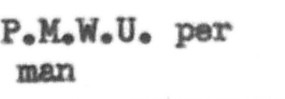 & 164 & 240 & 192 & 158 & 230 & 262 \\
\hline
\end{tabular}


TABLE XVI

Distribution of Labor Among the Iivestock Enterpilses Carried by Beginning Farmers in Fifteen Northern Missovus and Fourteen Southern Iowa Count1es During 1953, by Tenure Groups (mumber of P.M.W.U. Used by Bach Group)

\begin{tabular}{|c|c|c|c|c|c|c|}
\hline $\begin{array}{r}\text { Type of } \\
\text { Ifivestock }\end{array}$ & Owmer & $\begin{array}{l}\text { Part } \\
\text { Omer }\end{array}$ & Cash & $\begin{array}{l}\text { Crop } \\
\text { Share } \\
\end{array}$ & $\begin{array}{l}\text { Crop Share } \\
\text { Cash } \\
\end{array}$ & $\begin{array}{c}\text { Ifvestock } \\
\text { Share }\end{array}$ \\
\hline Beef Cattle & ב1 & $2 / 4$ & 10 & 9 & 17 & 59 \\
\hline Dairy Cattle & 53 & 49 & 61 & 16 & 54 & 44 \\
\hline Hogs & 8 & 28 & 20 & 9 & 15 & 30 \\
\hline Sheep and Poultry & 12 & 15 & 22 & 6 & 10 & 17 \\
\hline All ILvestock & 84 & 110 & & 40 & 96 & 150 \\
\hline
\end{tabular}


labor, and operator's labor were included. Very little hired labor was employed, but the operators who had livestock-share leases hired the most. Unpald family labor was also greatest on the livestock-share farms. Operators of partly-owned units spent more of their time on the farm than other groups, an average of 11.2 months. The total amount of available labor was greatest on livestock-share farms, wth an average of 12.8 months. Part-overs were second, with 12.4 months. Cash tenants had the amallest amount, with only 10.9 months. If the operator did not have an off-farm job, he was considered to have 12 months of labor aratlable.

Value of total sssets under operator's control. -The 152 men had an average of $\$ 26,035$ total assets under their control. The average amounts for each tenure group were: (1) owner-operators, \$13,954; (2) partmounere, \$25,347; (3) cash tenants, \$15,067; (4) crop-share tenant s, \$19,869; (5) crop-share-cash tenant s, \$28,376; and (6) livestock-share tenant s, $\$ 33,383$.

When only the farm assets were considered, the 152 men had an average of $\$ 19,377$ under their control (Table XVIII). The average amounts for each tenure group ware: (1) owner-operators, \$7,523; (2) part-ovmers, \$17,985; (3) cash tenant 8, \$10,683; (4) crop-share tenants, \$15,469; (5) crop-sharemcash tenants, \$22,303; and (6) Iivestock-share tenants, $\$ 24,625$.

Total sssets, total indebtedness, and net worth. - The data in Table XIX show the assets, liabilities, net worth, and changes in net worth of the various tenure groups at the beginning and and of 1953. 


\section{TABIS XVII}

Months of Hired, Unpald Family and Operator's Labor, and Total Months of Labor Available on the Farms of Beginning Farmers in Fifteen Northern Missourl and Fourteen Southern Iow Count1es, Durling 1953, by Temure Groups.

(Months used by tenure group)

\begin{tabular}{|c|c|c|c|c|c|c|}
\hline $\begin{array}{l}\text { Source of } \\
\text { Labor }\end{array}$ & Onner & $\begin{array}{l}\text { Part } \\
\text { Owner }\end{array}$ & Cash & $\begin{array}{l}\text { Crop } \\
\text { Share } \\
\end{array}$ & $\begin{array}{c}\text { Crop Share } \\
\text { Cash } \\
\end{array}$ & $\begin{array}{c}\begin{array}{c}\text { Livestock } \\
\text { Share }\end{array} \\
\end{array}$ \\
\hline Hired & .03 & .05 & - & .01 & .13 & .47 \\
\hline Unpaid Family & 1.31 & 1.11 & .53 & .49 & 1.00 & 1.35 \\
\hline Operator & 10.61 & 11.21 & $10 \cdot 40$ & 11.05 & 10.54 & 11.00 \\
\hline Total & 21.95 & 12.37 & 10.93 & ב. & 11.67 & 12.82 \\
\hline
\end{tabular}




\section{TABLE XVIII}

Size or Business in Terms of Total Farm Assets Under Operator's Control of Beginning Farmers in Flfteen Northern Missourl and Fourteen Southern Iowa Counties, According to Type of Tenure, Jan. I, 1953

\begin{tabular}{|c|c|c|c|c|c|c|}
\hline $\begin{array}{l}\text { Total farm } \\
\text { assets I/ }\end{array}$ & Onmer & $\begin{array}{l}\text { Part } \\
\text { Oumer }\end{array}$ & Cash & $\begin{array}{l}\text { Crop } \\
\text { Share } \\
\end{array}$ & $\begin{array}{c}\text { Crop Share } \\
\text { Cash }\end{array}$ & $\begin{array}{c}\text { If vestock } \\
\text { Share }\end{array}$ \\
\hline $\begin{array}{c}\text { Farm real } \\
\text { estate }\end{array}$ & $\$ 5,215$ & $\$ 15,020$ & $\$ 8,500$ & $\$ 13,772$ & $\$ 19,676$ & $\$ 21,987$ \\
\hline Livestock & 908 & 1,494 & 1,050 & 528 & 919 & 1,100 \\
\hline $\begin{array}{l}\text { Grop, reed } \\
\text { and supplies }\end{array}$ & 338 & 122 & 466 & 106 & 330 & 498 \\
\hline Machinery & 1,062 & 1,353 & 667 & 1,063 & 1,378 & 1,040 \\
\hline $\begin{array}{l}\text { Total farm } \\
\text { assets }\end{array}$ & $\$ 7,523$ & $\$ 17,985$ & $\$ 10,683$ & $\$ 15,469$ & $\$ 22,303$ & $\$ 24,625$ \\
\hline
\end{tabular}

1 The 152 operators had an average of $\$ 19,377$ of farm assets under their control. 


\section{TABLE XIX}

Assets, Lisbilities, and Net Worth of Beginning Farmers in Fifteen Northern Missourl and Fourteen Southern Iowa Counties, According to Type of Tenure, January 1, 1953 and December 31, 1953.

\begin{tabular}{|c|c|c|c|c|c|c|}
\hline & Owner & Part-Orener & Cash & Grop-Share & $\begin{array}{c}\text { Crop } \\
\text { Share-Cash }\end{array}$ & $\begin{array}{l}\text { Livestock } \\
\text { Share }\end{array}$ \\
\hline Item & $\begin{array}{cc}\text { Jan I } & \text { Dec 31 } \\
1953 & 1953\end{array}$ & $\begin{array}{cc}\text { Jan 1 } & \text { Dec 31 } \\
1953 & 1953\end{array}$ & $\begin{array}{cc}\text { Jan 1 } & \text { Dec 31 } \\
1953 & 1953\end{array}$ & $\begin{array}{cc}\text { Jan I } & \text { Dec 31 } \\
1953 & 1953\end{array}$ & $\begin{array}{cc}\operatorname{Jan} 1 & \mathrm{Dec} 31 \\
1953 & 1953\end{array}$ & $\begin{array}{cc}\operatorname{Jan} 1 & \text { Dec 31 } \\
1953 & 1953\end{array}$ \\
\hline
\end{tabular}

ASSETS

Machinery \&

Equipment

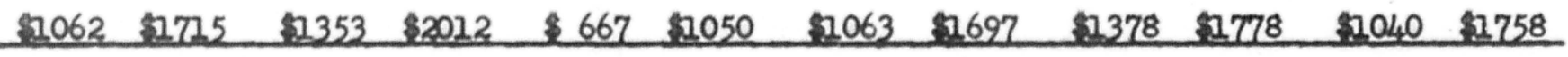

Crops, feed

\begin{tabular}{|c|c|c|c|c|c|c|c|c|c|c|c|c|}
\hline and supplies & 338 & 861 & 112 & 1428 & 466 & 1067 & 106 & 753 & 330 & $12 / 46$ & 498 & 1491 \\
\hline Livestock & 908 & 1624 & 1494 & 2558 & 1050 & 1433 & 528 & 963 & 919 & 2281 & 1100 & 2315 \\
\hline
\end{tabular}

Totel Par

\begin{tabular}{|c|c|c|c|c|c|c|c|c|c|c|c|c|}
\hline & 2308 & 4200 & 2959 & 5988 & 2183 & 3550 & 1697 & 3413 & 2627 & 530 & 263 & 5564 \\
\hline
\end{tabular}

\begin{tabular}{|c|c|c|c|c|c|c|c|c|c|c|c|c|}
\hline $\begin{array}{l}\text { Parm real } \\
\text { estate assets }\end{array}$ & 5215 & 6738 & 4559 & 7353 & - & - & - & - & - & 385 & 62 & 55 \\
\hline $\begin{array}{l}\text { TOTAL FARM } \\
\text { ASSETS }\end{array}$ & $\$ 7523$ & $\$ 10938$ & $\$ 7518$ & $\$ 13441$ & $\$ 2183$ & $\$ 3550$ & $\$ 2697$ & $\$ 3413$ & $\$ 2627$ & $\$ 5586$ & $\$ 2700$ & $\$ 5619$ \\
\hline $\begin{array}{l}\text { TOLAL MONFARM } \\
\text { BUSINESS ASSETS }\end{array}$ & 5792 & $\$ 423$ & $\$ 37$ & $\$ 376$ & $\$ 50$ & $\$ 50$ & $\$ 100$ & $\$ 119$ & $\$ 237$ & 123 & $\$ 63$ & $\$ 83$ \\
\hline $\begin{array}{l}\text { TOTAI FANIII } \\
\text { LIVING ASSETS }\end{array}$ & $\$ 1938$ & $\$ 1985$ & $\$ 1582$ & $\$ 1753$ & $\$ 1667$ & $\$ 1650$ & $\$ 1212$ & $\$ 1415$ & $\$ 1838$ & $\$ 2019$ & $\$ 1770$ & $\$ 1989$ \\
\hline
\end{tabular}

Continued 


\section{TABLE XIX, Continued}

Assets, Ilabilities, and Net Worth of Beginning Farmers in Fifteen Northern Missourl and Fourtean Southern Iowa Counties, According to Type of Tenure, January 1, 1953 and December 31, 1953.

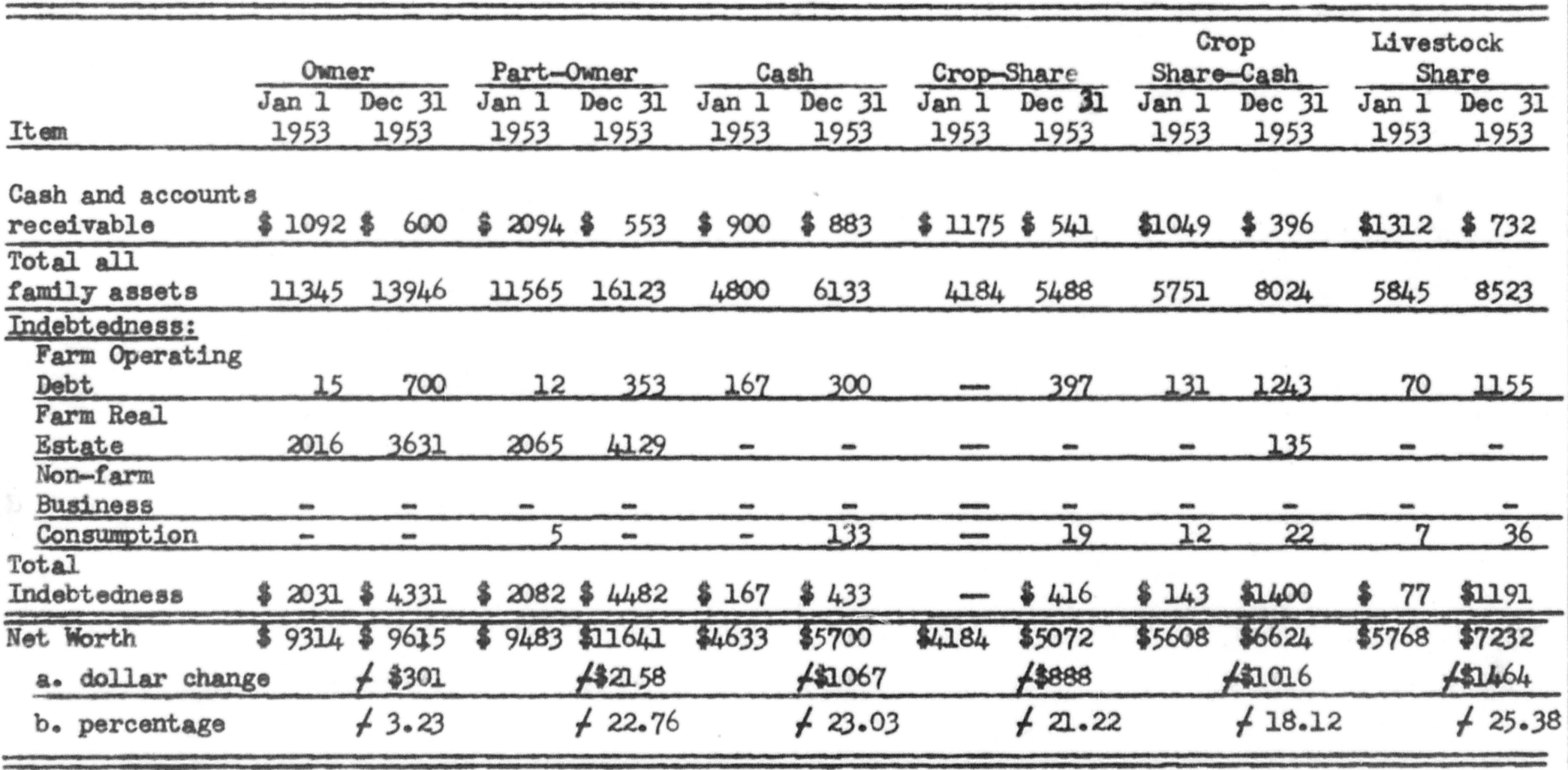


Partwowers had the largest net worth, both at the beginning and close of the year, and crop-share tenants the smallest.

Total indebtedness.-Farm real estate mortgages accounted for most of the debts, followed by farm operating debts. Total indebtedness increased for each tenure group. This situation can be regarded as normal. These men were starting in business and needed to gain control of additional capital in order to give them more desirable relationships between labor, land and equipment. The debts of partmowners increased the most $(\$ 2,400$, with $\$ 2,064$ of thos amount secured by farm real estate).

The net worth of each tenure group on January 1, 1953, was as follows: (1) part-ower, $\$ 9,483$; (2) owner-operators, $\$ 9,314$; (3) Iivestock-share tenants, $\$ 5,768$; (4) crop-share tenants, \$5,608; (5) cash tenants, \$4,633; and (6) holders of crop-share lesses, \$4,184. The members of each group incressed their net worth during 1953. The average amount was $\$ 1,197$, or 19.72 per cent. Part-owners had a $\$ 2,158$ increase, which was the largest for a single group. Owneroperators had a $\$ 301$ increase, which was the smallest change.

\section{Leasing Arrangements}

The data presented in Table $\mathrm{XX}$ show that 120 of the 152 operators from wom information was obtained were tenants, and 17 were partowners.

One hundred thirty-nine men rented at lesst one tract of land. Forty-four of these rented two tracts. Ten rented 3 tracts. The owner operators rented no land. As shown in Table $X X, 77$, or 56.2 per cent, of the men had oral leases on all their rented land. Forty-nine, or 


\section{TABLE XX}

Percent of Total Rented Land Held Under Written Lease and Number of Oral Leases Held by Beginning Farmers in Fifteen Northern Missouri and Fourteen Soutnern Iowa Counties in 1953 by Tenure Groups

\begin{tabular}{|c|c|c|c|c|c|c|c|}
\hline Item & $\begin{array}{l}\text { Owner } \\
\text { Operated }\end{array}$ & $\begin{array}{l}\text { Part } \\
\text { Onerer }\end{array}$ & Cash & $\begin{array}{l}\text { Crop } \\
\text { Share } \\
\end{array}$ & $\begin{array}{c}\text { Crop Share } \\
\text { Cash } \\
\end{array}$ & $\begin{array}{l}\text { Iivestock } \\
\text { Share }\end{array}$ & Total 1/ \\
\hline Oral lease (number) & & 12 & 4 & 23 & 9 & 29 & 77 \\
\hline \multicolumn{8}{|l|}{ Percent } \\
\hline $0-19$ & & & & & & & 0 \\
\hline $20-39$ & & & & & 1 & 1 & 2 \\
\hline $40-39$ & & & & & 1 & 2 & 3 \\
\hline $60-79$ & & & & & 1 & 1 & 2 \\
\hline $80-99$ & & & & & 1 & 3 & 4 \\
\hline 100 & & 5 & 2 & 8 & 23 & בע & 49 \\
\hline $\begin{array}{l}\text { Farming but no } \\
\text { rented land }\end{array}$ & 13 & & & & & & 13 \\
\hline Total & 13 & 17 & 0 & 31 & 36 & 47 & 150 \\
\hline
\end{tabular}


35.8 per cent of the men had written lesses on 100 per cent of their rented land. Fight per cent of the tenants had veltten leases on part of the rented land.

Seventy-two men did not have compensation clauses in their leases. Fifty-three had compensation clauses covering all of the land rented.

Labor share arrangement.-Twenty-five men had some form of labor share agreement, as shoven in Table XXI. Sixteen operators furnished labor only in a parent-son agreement. Ten of these were livestockshare tenants. Six men furnished labor and working capital in a parent-son agreement. Three of these were livestock-share tenants. Thirty-two per cent of the livestock-share tenants had labor-share arrangements. This was the greatest percentage for any temure group.

Nost veluable tracts rented.-Seventy-seven men did not have written leases on the mot valuable tracts rented. Flfty-nine men did have written leases.

The length of 54 leases wa indefinite. Seventymeight men had one-yaar contracts. One man had a two-year lease. A three-year lesse was obtained by 8 men, while 7 men had flve-year leases.

Seventy-two men did not have compensation clauses in their lesses. A compenstition clause was obtained by 36 of the men reporting.

Eighty-one men were related to the overs of the most valuable tract they were farming. Fifty-dix men were renting from non-related persons.

As shom in Table XXII, 55 men were renting from an active farmer wthin 50 miles of the farm. Thirty-two were renting from a retired 


\section{TABLE XXI}

Labor Share Arrangements of Beglnning Farmers in Flfteen Northern Missouri and Fourteen Southern Iowe Counties During 1953, by Tenure Groups, (Number of Operators in Each Group)

\begin{tabular}{|c|c|c|c|c|c|c|c|}
\hline $\begin{array}{l}\text { Labor Share } \\
\text { Arrangements }\end{array}$ & $\begin{array}{l}\text { Omer } \\
\text { Operator }\end{array}$ & $\begin{array}{l}\text { Part } \\
\text { Ormer }\end{array}$ & Cash & $\begin{array}{l}\text { Crop } \\
\text { Share } \\
\end{array}$ & $\begin{array}{c}\text { Crop Share } \\
\text { Cash } \\
\end{array}$ & $\begin{array}{l}\text { Ifivestock } \\
\text { Share }\end{array}$ & Total \\
\hline $\begin{array}{l}\text { No labor share } \\
\text { arrangement }\end{array}$ & 13 & 15 & 5 & 26 & 36 & 32 & 127 \\
\hline $\begin{array}{l}\text { Parent-son-puts up } \\
\text { labor only }\end{array}$ & & 1 & & 4 & 1 & 10 & 16 \\
\hline $\begin{array}{l}\text { Parent-son-puts up } \\
\text { labor and workding capdtal }\end{array}$ & & 1 & 1 & 1 & & 3 & 6 \\
\hline $\begin{array}{l}\text { Other relative-puts up } \\
\text { labor only }\end{array}$ & & & & & & 1 & 1 \\
\hline $\begin{array}{l}\text { Non-relative-puts up } \\
\text { labor anly }\end{array}$ & & & & 1 & & & 1 \\
\hline $\begin{array}{l}\text { Non-relative-puts up } \\
\text { labor and working capttal }\end{array}$ & - & - & - & - & - & 1 & 1 \\
\hline Total & 13 & 17 & 6 & 32 & 37 & 47 & 152 \\
\hline
\end{tabular}




\section{TABLE XXII}

Type of Landlord of Most Valuable Tracts Rented by Beginning Farmers in Fifteen Northern Missouri and Four teen Southern Iows Counties in 1953 By Tenure Groups

(Number of operstors in each group)

\begin{tabular}{|c|c|c|c|c|c|c|}
\hline Type of Landlord & $\begin{array}{l}\text { Part } \\
\text { Ovener I }\end{array}$ & Cash & $\begin{array}{l}\text { Grop } \\
\text { Share }\end{array}$ & $\begin{array}{l}\text { Crop Share 2/ } \\
\text { Cash }\end{array}$ & $\begin{array}{l}\text { Livestock } \\
\text { Share }\end{array}$ & Total 3/ \\
\hline Active farmer within $50 \mathrm{miles}$ & 10 & 1 & 12 & 7 & 25 & 55 \\
\hline Retired farmer within $50 \mathrm{mfles}$ & 2 & 3 & 8 & 11 & 8 & 32 \\
\hline Active farmer over $50 \mathrm{miles}$ & 1 & & 1 & & 1 & 3 \\
\hline Retired farmer over $50 \mathrm{mbles}$ & & & & & & 0 \\
\hline Nonfarm person within 50 miles & 1 & 2 & 7 & 11 & 8 & 29 \\
\hline Nonfarm person over $50 \mathrm{mflles}$ & 1 & - & 4 & 6 & 5 & 16 \\
\hline Total & 15 & 6 & 32 & 35 & 47 & 135 \\
\hline $\begin{array}{l}\text { 1/ Fifteen reporting } \\
\text { 2/ Thirty-five reporting } \\
3 / \text { Thirteen ower-operators had }\end{array}$ & Ited land. & & & & & \\
\hline
\end{tabular}


farmer wthin 50 miles. The third major type of landlord ws a nonfarming person within 50 miles. Twenty-nine were renting from this type of owner.

Second most valuable tract rented.- Heven of the 54 men who were renting a second tract of land had vaitten leases. Thirty-five had one-jear contracts. Seventeen had inderinite term leases. One man had a two-year lease. A five-year lease was held by one man.

Twenty-one of the 54 men had compensation clauses in their leases. Twenty-nine were related to the landlord.

As shown in Table XXIII, 20 men rented from active farmers who lived vithin $50 \mathrm{mlles}$. Fourteen men rented from retired farmers $x$ ithin 50 miles. The third major type of landlord was a non-farm person who lived within 50 miles of the farm. Thirteen men rented from this type of landlord.

Important sources of land farmed.-Seventy of the men were farming land that was owned by their parents (Table XXIV). Kany others had been able to get leases because they were personally acquainted with the over of the land.

As shown in Table XXV, the men farming two or more tracts considered personal acquaintance with the landlord to be the second most important factor in getting a lease on the land.

Net Farm Income

Net farm income was computed by determining the net farm operating income plus or mimus net change in value of inventories. As shown in Table XXVI, the aversge net farm income for each tenure group 
TABLE XXIII

Type of Landlord on Second Most Valuable Tract Rented by Beginning Farmers in Fifteen Northern Missouri and Fourteen Southern Iowa Counties in 1953 by Tenure Croups

(Number of operators in each group)

\begin{tabular}{|c|c|c|c|c|c|c|}
\hline Type of Landlord & $\begin{array}{l}\text { Part } \\
\text { Owner }\end{array}$ & Cash & $\begin{array}{l}\text { Crop } \\
\text { Share }\end{array}$ & $\begin{array}{l}\text { Crop Share IJ } \\
\text { Cash }\end{array}$ & $\begin{array}{l}\text { Lf vestock } 2 / 1 \\
\text { Share }\end{array}$ & Total 3/ \\
\hline Active farmer within $50 \mathrm{miles}$ & 4 & & 4 & 5 & 7 & 20 \\
\hline Retired famer within 50 miles & 1 & 1 & 3 & 3 & 6 & 14 \\
\hline Active farmer over 50 miles & & & 1 & & 1 & 2 \\
\hline Retired farmer over $50 \mathrm{mfles}$ & & & & & & 0 \\
\hline Nonfarm person within 50 miles & 1 & & 1 & 8 & 3 & 13 \\
\hline Nonfarm person over $50 \mathrm{mlles}$ & & & & & 3 & 3 \\
\hline No second rented tracts & $\underline{11}$ & 5 & 23 & 20 & 26 & 85 \\
\hline Total & 17 & 6 & 32 & 36 & 46 & 137 \\
\hline $\begin{array}{l}\text { 1/ Thirty-six reporting } \\
\text { 2/ Forty-six reporting } \\
\text { 3/ Thirteen ower-operators had }\end{array}$ & ented & & & & & \\
\hline
\end{tabular}




\section{TABIE XXIV}

Yost Important Source or Iand Farmed by Beginning Farmers in Fifteen Northern Missourl and Fourteen Southern Iore Counties During 1953, by Tenure Groupe (Number of Operators in Bach Group)

\begin{tabular}{|c|c|c|c|c|c|c|c|c|}
\hline & Onener & $\begin{array}{l}\text { Part } \\
\text { Omer }\end{array}$ & Cash & $\begin{array}{l}\text { Crop } \\
\text { Share }\end{array}$ & $\begin{array}{l}\text { Crop Share } \\
\text { Cegh } \\
\end{array}$ & $\begin{array}{c}\text { Ifvestock } \\
\text { Share } \\
\end{array}$ & Toter I/ & \\
\hline \multicolumn{2}{|l|}{$\begin{array}{l}\text { Used land onened } \\
\text { by parents }\end{array}$} & 8 & 5 & 15 & 7 & 35 & 70 & \\
\hline \multicolumn{2}{|l|}{$\begin{array}{l}\text { Used lsmd rented } \\
\text { by parents }\end{array}$} & 1 & & 1 & 1 & & 3 & \\
\hline \multicolumn{2}{|c|}{$\begin{array}{l}\text { Ind oned by other } \\
\text { relatives }\end{array}$} & & & 1 & 1 & 4 & 6 & \\
\hline \multicolumn{3}{|c|}{$\begin{array}{l}\text { Iand rented by other } \\
\text { relatives }\end{array}$} & & & 1 & & 1 & \\
\hline \multicolumn{2}{|c|}{$\begin{array}{l}\text { Rented Iand through } \\
\text { relatives' help }\end{array}$} & & & 1 & 9 & 3 & 13 & \\
\hline Inherited Iand & 1 & 2 & & & & & 3 & \\
\hline $\begin{array}{l}\text { Bought land with } \\
\text { fand if ald }\end{array}$ & 3 & 2 & & & & & 5 & \\
\hline \multicolumn{2}{|l|}{$\begin{array}{l}\text { Bought Iand wit } h \text { - } \\
\text { out family aid }\end{array}$} & 3 & & & 1 & & 13 & \\
\hline \multicolumn{2}{|c|}{$\begin{array}{l}\text { Personal acquain- } \\
\text { tance wdth Iandlord }\end{array}$} & 1 & 1 & 12 & 15 & 5 & 34 & w \\
\hline Total I/ 148 report & $\begin{array}{c}13 \\
\text { ting. }\end{array}$ & 17 & 6 & 30 & 35 & 47 & $u_{48}$ & \\
\hline
\end{tabular}




\section{TABLES XXV}

Second Yost Important Source of Iand Farmed by Beginning Farmers in Fifteen Northern Missourl and Fourteen Southern Iow Counties During 1953, by Tenure Groups (Number of Operators in each Group)

\begin{tabular}{|c|c|c|c|c|c|c|}
\hline Onerer & $\begin{array}{l}\text { Part } \\
\text { Orner }\end{array}$ & Cash & $\begin{array}{l}\text { Crop } \\
\text { Share }\end{array}$ & $\begin{array}{c}\text { Crop Share } \\
\text { Cash }\end{array}$ & $\begin{array}{c}\text { Iivestock } \\
\text { Share }\end{array}$ & Total \\
\hline $\begin{array}{l}\text { Used land ovened } \\
\text { by parents }\end{array}$ & 1 & & 1 & 4 & 1 & 7 \\
\hline $\begin{array}{l}\text { Used land rented } \\
\text { by parents }\end{array}$ & & & & 1 & 2 & 3 \\
\hline $\begin{array}{l}\text { Iand ovened by other } \\
\text { relatives }\end{array}$ & 1 & & 2 & 1 & & 4 \\
\hline $\begin{array}{l}\text { Iand rented by } \\
\text { other relatives }\end{array}$ & & & & 1 & & 1 \\
\hline $\begin{array}{l}\text { Rented land through } \\
\text { rolatives' nelp }\end{array}$ & & & 1 & 1 & 1 & 3 \\
\hline Inherited Iand & 1 & & & & & 1 \\
\hline $\begin{array}{l}\text { Bought land with } \\
\text { fandly aid }\end{array}$ & 5 & & & & & 5 \\
\hline $\begin{array}{l}\text { Bought land without } \\
\text { randly atd }\end{array}$ & 3 & & & & & 3 \\
\hline $\begin{array}{l}\text { Perscenal acquaintance } \\
\text { with landlord } \\
\text { Total }\end{array}$ & $\begin{array}{r}6 \\
17\end{array}$ & 0 & $\begin{array}{l}4 \\
8\end{array}$ & $\begin{array}{r}6 \\
14\end{array}$ & 17 & $\begin{array}{l}23 \\
50\end{array}$ \\
\hline
\end{tabular}




\section{TABLB XXVI}

Net Fandily Income of Beginning Farmers in Fifteen Northern Nissourl and Fourteen Southern Iown. Counties in 1953, According to Type of Tenure

\begin{tabular}{|c|c|c|c|c|c|c|}
\hline $\begin{array}{c}\text { Source of } \\
\text { Inceme }\end{array}$ & Oaner & $\begin{array}{l}\text { Part } \\
\text { Onner }\end{array}$ & Csgh & $\begin{array}{r}\text { Crop } \\
\text { Share } \\
\end{array}$ & $\begin{array}{l}\text { Crop Share } \\
\text { Cash }\end{array}$ & $\begin{array}{c}\text { Ifivestock } \\
\text { Snare }\end{array}$ \\
\hline $\begin{array}{l}\text { Xet farm operating } \\
\text { Income }\end{array}$ & $\$ 1,254$ & $\$ 2,606$ & $\$ 1,167$ & $\$ 1,575$ & $\$ 1,981$ & $\$ 2,123$ \\
\hline $\begin{array}{l}\text { Net farm real } \\
\text { estate income }\end{array}$ & -423 & -472 & - & - & - & - \\
\hline Net farm income & 831 & 2,194 & 1,167 & 1,575 & 1,981 & 2,123 \\
\hline Off farm income & 931 & 729 & 1,167 & 678 & 613 & 660 \\
\hline Girts & 38 & 1,035 & 600 & 322 & 238 & 372 \\
\hline Net rand Iy income & $\$ 1,800$ & $\$ 3,958$ & $\$ 2,934$ & $\$ 2,575$ & $\$ 2,832$ & $\$ 3,355$ \\
\hline
\end{tabular}


was: (1) part-owmers, \$2,194; (2) livestock-share lesse holders, \$2,123; (3) crop-share-cash tenant 8, \$1,981; (4) crop-share tenants, $\$ 1,575$; (5) cash renters, $\$ 1,167$; and (6) ovmer-operators, \$831. Average gross recilpts from livestock and farm produce sales were as follows:

\begin{tabular}{lrccc} 
Tenure & Iivestock & Farm Produce & Total \\
\cline { 5 - 5 } Part-owner & $\$ 1,865$ & $\$ 1,465$ & $\$ 3,330$ \\
Livestock-share & 1,851 & 996 & 2,847 \\
Grop-share-cash & 1,181 & 1,508 & 2,689 \\
Crop-share & 850 & 1,706 & 2,556 \\
Cash tenant & 933 & 1,333 & 2,266 \\
Omer-operator & 908 & 1,231 & $2,139$.
\end{tabular}

\section{Non-Farm Income}

Non-farm income included the off-farm earnings of husband and wfe, on-the-farm training payments, off-farm business profits, rent, interest, and change in nonfarm business assets.

Seventymo men worked off their farms an average of 3.5 months during 1953, as shove in Table XXVII. The average 1ncome was $\$ 973$. Custom work for other farmexs was the major type. Non-akdlled Industrial labor was the second major type. The wives of some of these men also had off-farm jobs. Most of them were employed as teachers, bookkeepers, or secretarles. The average off-farm income per family for Wives who worked was $\$ 1,223$.

The average off-farm income for esch temure group was as follows: (1) cash tenants, \$1,167; (2) ownermoperators, \$931; (3) part-owners, 


\section{TARTB XXVII}

Type of Bmployment, TIme Spent, and Income From Off-farm Work by Beginning Farmers (Operator and Wife) in Fifteen Horthern Kissourl and Fourteen Southem Iown Count1es, During 1953, Accerding to Type of Tenure

\begin{tabular}{|c|c|c|c|c|c|c|c|c|}
\hline \multirow[b]{2}{*}{$\begin{array}{l}\text { Type } \\
\text { of } \\
\text { Temare }\end{array}$} & \multicolumn{4}{|c|}{ Operator } & \multicolumn{4}{|c|}{ wise } \\
\hline & $\begin{array}{l}\text { Number } \\
\text { woriding }\end{array}$ & $\begin{array}{l}\text { Kajor type } \\
\text { of off-fam } \\
\text { work } \mathrm{V}\end{array}$ & $\begin{array}{l}\text { Average } \\
\text { Income }\end{array}$ & $\begin{array}{l}\text { Average number } \\
\text { of months of } \\
\text { off-farm work }\end{array}$ & $\begin{array}{l}\text { Number } \\
\text { workding }\end{array}$ & $\begin{array}{l}\text { Major type } \\
\text { of orf-rarm } \\
\text { work } ?]\end{array}$ & $\begin{array}{l}\text { Average } \\
\text { Income }\end{array}$ & $\begin{array}{l}\text { Average number } \\
\text { of months of } \\
\text { off-farm work }\end{array}$ \\
\hline Omer & 6 & 1, 7 & $\$ 1,258$ & 4.1 & 2 & 5,3 & $\$ 905$ & 7.0 \\
\hline Part onener & 6 & 1 & 938 & 3.2 & 2 & 4,5 & 905 & 0.1 \\
\hline Gash & 4 & 1 & 1,258 & 3.4 & 1 & 3 & 1,750 & 12.0 \\
\hline Crop share & 15 & 1 & 778 & 2.7 & 5 & 3,4 & 1,282 & 6.8 \\
\hline $\begin{array}{l}\text { Crop } \\
\text { Share-cash }\end{array}$ & 22 & 1 & 872 & 3.8 & 3 & 3,4 & 917 & 6.3 \\
\hline $\begin{array}{l}\text { IAvestock } \\
\text { Share }\end{array}$ & 18 & 1 & 1,115 & 3.8 & 5 & 3,4 & 1,490 & $9 \cdot 4$ \\
\hline Total & $n$ & 1 & $\$ 973$ & 3.5 & 18 & 3 & $\$ 1,228$ & 7.7 \\
\hline
\end{tabular}

I Types Iisted below by number:
(1) Farm work
(2) Agar cultural services
(5) Public service (non-skdlied)
(3) Bducation
(o) Public service (skdlled)
(9) Private business
(4) Bookkeeping and secretarial
(7) Industrial (non-skd lled)
(8) Industrial (sklled) 
\$729; (4) crop-share tenants, \$678; (5) Iivestock-share lease holders, $\$ 660$; and (6) crop-share-cash renters, \$613. Cash tenants had the largest net off-farm income (Table XXVI). Gifts

The average dollar value of glfts recelved in 1953 for ech tenure group was: (1) part-owners, $\$ 1,035$; (2) cash tenants, $\$ 600$;

(3) Iivestock-share lesse holders, \$572; (4) crop-share tenants, \$322; (5) crop-share-cash renters, \$238; and (6) owner-operators, \$38. One part-owner wa given a farm valued at $\$ 12,000$. This amount incressed the average of the 17 part-owners by $\$ 706$.

\section{Net Fambly Inceme}

The family income included net farm income, returns from off-farm work, and gifts. Part-owners had net family incomes of \$3,958. If the gift of $\$ 12,000$ recedved by one operator was removed, the average nould be $\$ 3,252$. Ifvestock-share tenant 8 averaged $\$ 3,355$; cash tenants, \$2,934; crop-sharomessh tensint \$, \$2,832, and crop-share tenant 8, \$2,575. Omer-operators had the smallest net family incomes with an average of $\$ 1,800$.

Iabor Income to Family, Iabor Income to Operator, and Return to Nanagement

Net farm income minus a 5.0 per cent return to the average farm net worth equals labor income to a family.

When the value of the unpald family labor is deducted from labor income to the family, the remainder is the labor and mansgement income of the operator. 
The value of operator's labor was taken as \$1,500 for twalve months. Iabor and management income to the operator minus the value of his labor leaves returns to management.

As shovm in Table XXVII, livestock share tenants had an average of \$1,947 labor income. This was the highest for and tenure group. Oner-operators had the smallest average of $\$ 508$.

The labor and management income to the operator was the greatest on farms operated under l1vestock-share leases (Table XVVIII). They had an average of $\$ 1,81$. Part-ovmers, crop-share-cash tenants, cropshare renters, cash tenants and ovnermperators follow in the order of hlghest to lowest. Owner-operators averaged $\$ 392$ return for labor and management. They had a negative return to management, as did cash tenants (Table XXVIII). The other tenure groups had positive returns to management. Livestockmehare tenants averaged \$434, which was the highest of the six tenure groups.

\section{THB FARM BUSTNESS DN 1955}

The analysis of the farm businesses in 1955 was based on type of tenure of the operators in 1953.

\section{Size of Business}

Total acres.-The average size farm in terms of total acres in 1955 was as follows: (1) 11vestock-share tenants, 254; (2) partowners, 236; (3) crop-share-cash tenants, 234; (4) erop-share, 213; (5) cash tenants, 173; and (6) ownex-perators, 167. The average size of all farms was 228 acres. The average incresse in size from 1953 to 1955 was 32 acres, or 16.3 per cent. Bech tenure group showed an 
TABTE XVIII

Iabor Income to FandIJ, Iabor and Nenagement Incone to Operator and Returns to Nanagement in 1953, Beginning Farmers in Flfteen Northern Milsoury and Fourteen Southern Iow Counties, According to Type of Tenure.

\begin{tabular}{|c|c|c|c|}
\hline Tenure Group & $\begin{array}{c}\text { Iabor Incone } \\
\text { to Fandiy }\end{array}$ & $\begin{array}{l}\text { Iaber and Nans: } \\
\text { agement Income } \\
\text { of Operator }\end{array}$ & $\begin{array}{l}\text { Return To } \\
\text { Nenagement }\end{array}$ \\
\hline Onener-Operator & +508 & $\$ 392$ & $-\$ 938$ \\
\hline Part-Orener & $\$ 1,829$ & $\$ 1,124$ & $f \$ 323$ \\
\hline Cash Tenent & $\$ 1,033$ & $\$ 983$ & $-\$ 317$ \\
\hline Crop Share & $\$ 1,4>3$ & $\$ 1,397$ & $f$ \\
\hline Crop Share Cash & $\$ 1,819$ & $\$ 1,76$ & $f \$ 403$ \\
\hline Ifvestock Share & $\$ 1,947$ & $\$ 1,81$ & +434 \\
\hline
\end{tabular}


increase, but cash tenmints weht up the most (73.0 per cent). Partowmers had the smallest increase ( 8.2 per cent).

Acres of cropland. including har and rotation pasture. - The average acreage of cropland and rotation pasture held by all tenure groups was 133 acres. This represented a 17.0 per cent increase in the 1953-55 three-year period. The acreage for each tenure group was as follows: (1) cropmshare-cash renters, 148 acres; (2) part-omers, 143 acres; (3) IIvestock-share lesse holders, 237 acres; (4) crop-share tenants, 135 acres; (5) cash rent $\mathrm{rs}, 110$ acres; and (6) oven-operators, 76 acres.

Cash tenants had an average increase of 92.9 per cent. Ovemoperators had the smallest increase, 5.5 per cent.

Acres of corn. whest and sorbeang. - The highest proflt crops in the area are corn, wheat and soybeans. In 1953 the average acreage of these crops was 66.3 acres. In 1955 it was 75 acres, an 8.7 per cent Increase. Grop share tenants led all groups with 86 acres. Cropmsharecash renters had 82 acres; partwowers, 81; I1vestock-share lease holders, 74; cesh renters, 50; and over-operators, 35. Omer-operators decressed the acresge of these high return crops 19.5 per cent between 1953 and 1955. The other tenure groups increased the acreage in corn, wheat and soybeans. Cash tenants Incressed the largest amount, with a gain of 78.6 per cent.

Productive man work units.-As shown in Table XXIX, total P.M.W.U. requirements were the grestest on farms operated under livestock-share 1esses. Omer-operators required the least amount of labor to tsike eare of their enterprises. All temure groups increased their P.M.W.U. 
TABLE $X X I X$

S1ze of Businesses Operated by Farmers Who Started in Business in 1953 and S1ze in 1955, Measured in Productive Man Work Units by Tenure Groups, Fyfteen Northern Missourl and Fourteen Southern Iowa Count1es.

\begin{tabular}{|c|c|c|c|c|c|c|c|}
\hline \multirow{2}{*}{$\begin{array}{l}\text { Tenure } \\
\text { Group }\end{array}$} & \multicolumn{3}{|c|}{$\begin{array}{l}1953 \\
\text { PMWU } \\
\end{array}$} & \multicolumn{4}{|c|}{$\begin{array}{l}1955 \\
\text { PMANO }\end{array}$} \\
\hline & Grop & Investock & Tot, 2 & Grop & Ifvestock & Other & Total \\
\hline $\begin{array}{l}\text { Ovener- } \\
\text { Operators }\end{array}$ & 79 & 84 & 163 & 78 & 122 & 5 & 195 \\
\hline Part-Owners & 119 & 116 & 235 & 149 & 189 & 1 & 339 \\
\hline Cssh Renters & 63 & 113 & 176 & 110 & 170 & - & 280 \\
\hline $\begin{array}{l}\text { Crop Share } \\
\text { Tenants }\end{array}$ & 112 & 40 & 152 & 133 & 109 & - & 242 \\
\hline $\begin{array}{l}\text { Crop Share } \\
\text { Cash Tenant s }\end{array}$ & 129 & 96 & 225 & 159 & 174 & - & 333 \\
\hline $\begin{array}{l}\text { Livestock } \\
\text { Share } \\
\text { Tenants }\end{array}$ & 133 & 150 & 283 & 147 & 213 & - & 360 \\
\hline
\end{tabular}


requirements from 1953 to 1955. The greatest advance was made by the cash tenants (59 per cent). Efflciency in the use of labor went up as the businesses were enlarged. The P. M. W. U. per man increased for all tenure groups (Table XXX). Part-omers advanced from 240 units per man in 1953 to 365 in 1955. Livestock-share tenants increased their work load from 262 per man in 1953 to 333 in 1955. Their efficiency in the use of labor was the lowest of all the tenure groups. Part-owners had the largest gain in efficiency during the three-year period. The work accomplished per man in this group went up 47.9 per cent.

The P.M.W.U. requirements were greater for livestock than for crops in all tenure groups except businesses operated by crop-share tenants. Livestock-share lease holders had the largest labor requirements for livestock, with an average of 213. As show in Table XXXI, the livestock enterprise requiring the greatest number of P.M.W.U. was dairy, with the exception of the livestock-share group. The labor requirements of beef cattle were the greatest there.

All tenure groups increased the size of their enterprises from 1953 to 1955. Crop-share tenants increased their work requirements for I1vestock 69 units, or 172 per cent, for the largest gain.

As show in Table XXXII, 11vestock-share tenants had the greatest amount of avallable labor on their farms. However, the man equivalent did not change between 1953 and 1955. The work accomplished per man did increase, indicating a gain in efficiency in the use of labor between 1953 and 1955. Cash tenants were the only group that did not increase the days of labor hired. No labor was hired either year by 
TABLE $\mathbf{X X X}$

Efficlency in Use of Labor by Operators Who Started Farming in 1953 As Show By Work Units Accomplished Per Man Equivalent, Fifteen Northern Missour1 and Fourteen Southern Iowa Count1es, According to Type of Tenure.

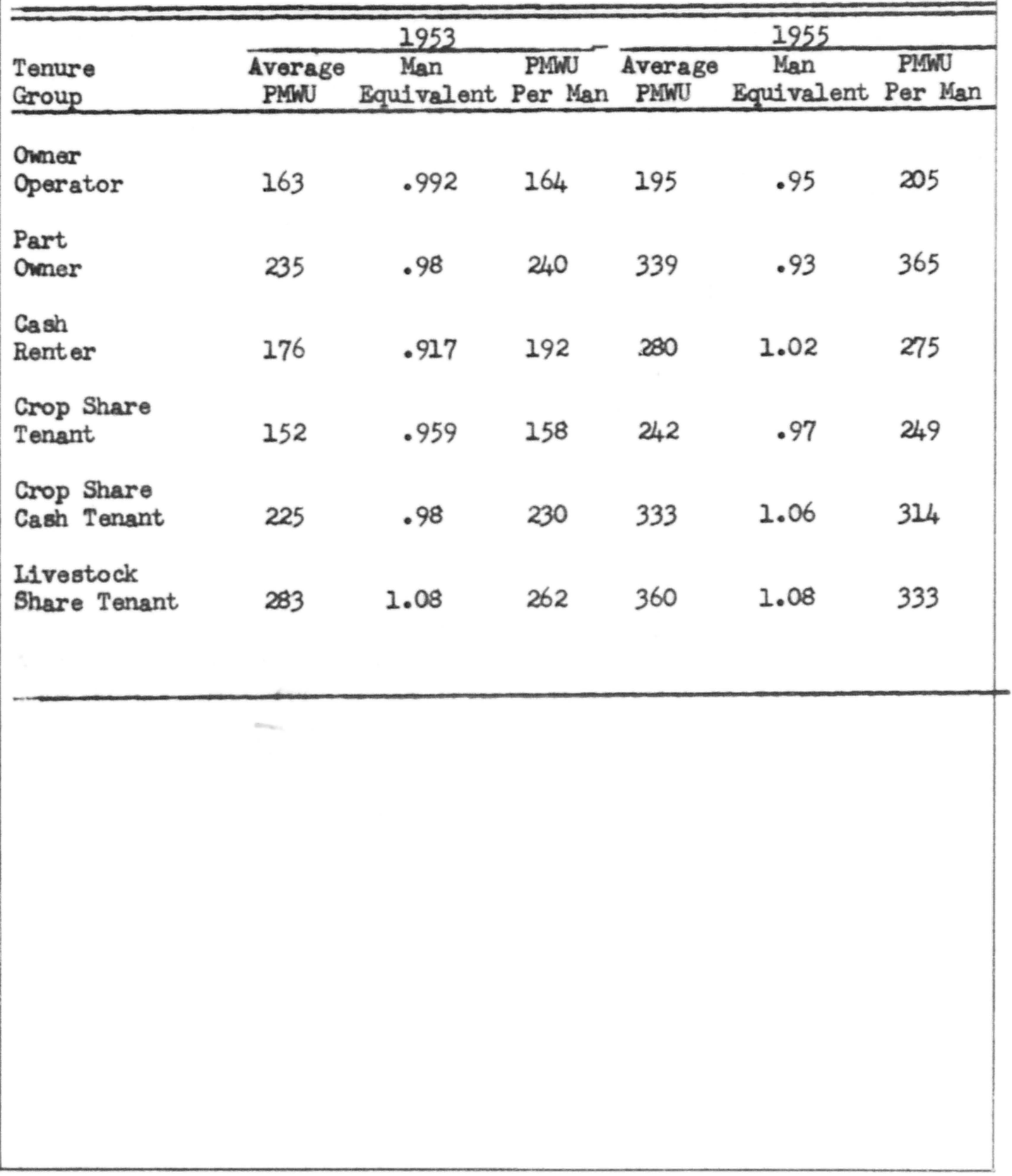




\section{TABLE XXXI}

Productive Man Work Units Used on Different Types of Livestock in 1955, by Beginning Farmers in Fifteen Prod ing in 1953, (P.M.W.U. Used by Each Tenure Group)

\begin{tabular}{|c|c|c|c|c|c|c|}
\hline $\begin{array}{l}\text { Type of } \\
\text { Ifivestock }\end{array}$ & Owner & Part Owner & Cash & Crop Share & $\begin{array}{c}\text { Crop Share } \\
\text { Cash } \\
\end{array}$ & $\begin{array}{c}\text { Isivestock } \\
\text { Share }\end{array}$ \\
\hline Beef Cattle & 16 & 40 & 18 & 23 & 31 & 75 \\
\hline Dairy Cattle & $\infty 0$ & 75 & 97 & 35 & 17 & 24 \\
\hline Hogs & 22 & 44 & 33 & 33 & 48 & 38 \\
\hline Sneep and Poultry & 14 & 30 & 22 & 18 & 18 & 26 \\
\hline All Iivestock & 122 & 189 & 170 & 109 & 174 & 2213 \\
\hline
\end{tabular}




\section{TABISE XXXII}

Montns or Hired, Unpaid Family and Operator's Labor, and Total Konths of Labor Available on tne Farms or Beginning Farmers in Firteen Nortnerm Missourl and Fourteen Southern Iows Count1es During 1935 by Type of Tenure or the Operators When They Started Farming in 1953

\begin{tabular}{|c|c|c|c|c|c|c|}
\hline $\begin{array}{c}\text { Labor } \\
\text { (montns) }\end{array}$ & Owner & Part Owner & Cash & Crop Snare & $\begin{array}{c}\text { Crop Snare } \\
\text { Casn } \\
\end{array}$ & $\begin{array}{c}\text { Livestock } \\
\text { Share }\end{array}$ \\
\hline HIred & .06 & .43 & - & .13 & .44 & .39 \\
\hline Unpaid Fand & 1.35 & 1.33 & 1.47 & .74 & 1.13 & 1.40 \\
\hline Operator & 10.00 & 10.49 & 10.00 & 10.78 & 11.07 & 10.78 \\
\hline Total & 11.47 & 12.29 & 12.13 & 11.63 & 12.00 & 12.83 \\
\hline
\end{tabular}


this group.

The months of unpaid family labor increased in all temure groups over the three-year period, 1953 to 1955, but operators' available labor for farm work decressed in the ovner-operator, part-owner, cropshare, and I1vestock-share groups. These men spent an increasing amount of time working off their farms.

The total months of labor used in operating the farms decreased from 1953 to 1955. Apparently the operators who were unable to expand their businesses by adding more acres or larger or more intensive enterprises turned to off-farm work. This situation particularly evident among owner and part-owner operators. The amount of availatle labor remained constant on crop-share-cash and livestock-share farms. The total months of labor avalable to cash and crop-share tanants increased.

Total farm assets under operator's control. - hs shown in Table XXXIII, the total value of business assets avallable to livestockshare tenant averaged $\$ 24,625$ at the time these men started farming in 1953. By 1955 the business assets controlled by these men had increased to \$32,873. This was the largest for anj tenure group. The value of farm assets controlled by owner-operators averaged $\$ 7,523$ in 1953 and $\$ 2,678$ in 1955, the smallest amount for any tenure group. The value of farm real estate alone for the other tenure groups was larger than all of the farm aseets of the ovmem-operstors. The average value of assets controlled by all of the 152 men in 1955 was $\$ 28,470$. This anount 46.9 per cent grester than in 1953. The increase by tenure groups is given in Table XXXIII. Cash tenants made the greatest 


\section{TABLES XXXIII}

Total Business Capital Available to Farm Operators Who Started Farming in 1953, at the THme They

Started and on Jamuary 1, 1955, by Tenure Groups, F1fteen Northern Missourl and Fourteen Southern Iow Counties

\begin{tabular}{|c|c|c|c|c|c|c|c|c|c|c|}
\hline \multirow[b]{2}{*}{$\begin{array}{l}\text { Tenure } \\
\text { Group }\end{array}$} & \multicolumn{10}{|c|}{ Type and Value of Business Assets } \\
\hline & $\begin{array}{l}\text { Parm } \\
\text { Real } \\
\text { Estate }\end{array}$ & $\begin{array}{l}\text { Live- } \\
\text { stock }\end{array}$ & $\begin{array}{l}\text { Feed and } \\
\text { Supplies } \\
\end{array}$ & $\begin{array}{l}\text { Machinery } \\
\text { and } \\
\text { Equipment }\end{array}$ & Total & $\begin{array}{l}\text { Farm } \\
\text { Real } \\
\text { Bstate } \\
\end{array}$ & $\begin{array}{l}\text { Live- } \\
\text { stock }\end{array}$ & $\begin{array}{l}\text { Peed and } \\
\text { Supplies } \\
\end{array}$ & $\begin{array}{l}\text { Machinery } \\
\text { and } \\
\text { Equipment }\end{array}$ & Total \\
\hline $\begin{array}{l}\text { Ovener- } \\
\text { Operator }\end{array}$ & $\$ 5,225$ & $\$ 908$ & $\$ 338$ & $\$ 1,062$ & $\$ 7,523$ & $\$ 7,917$ & $\$ 1,838$ & $\$ 700$ & $\$ 2,223$ & $\$ 2,678$ \\
\hline $\begin{array}{l}\text { Part- } \\
\text { Ovenex }\end{array}$ & 15,026 & 1,494 & 112 & 1,353 & 7,985 & 19,547 & 3,053 & 1,935 & 2,941 & 27,476 \\
\hline Cash Renter & 8,500 & 1,050 & 466 & 667 & 10,683 & 21,340 & 2,633 & 984 & 1,683 & 26,640 \\
\hline $\begin{array}{l}\text { Crop Share } \\
\text { Tenant }\end{array}$ & 13,772 & 528 & 106 & 1,063 & 15,469 & 19,918 & 2,006 & 1,222 & 2,503 & 25,649 \\
\hline $\begin{array}{l}\text { Crop Share } \\
\text { Cash Tenant }\end{array}$ & 19,676 & 919 & 330 & 1,378 & 22,303 & 24,199 & 3,062 & 1,552 & 2,803 & 31,618 \\
\hline $\begin{array}{l}\text { Ifvestock } \\
\text { Share } \\
\text { Tenant }\end{array}$ & 21,987 & 1,100 & 498 & 1,040 & 24,625 & 25,462 & 3,002 & 1,781 & 2,628 & 32,873 \\
\hline
\end{tabular}


gain. The value of business assets under their control in 1955 was almost 1.8 times as great as in 1953. All of the other tenure groups gained control of additional sssets, too. Total Assets, Total Indebtedness, and Net Worth

The data in Table XXXIV show average assets, indebtedness, and net worth of each temure group on January 1, 1953, and on December 31, 1955. Part-onmers had asset 8 valued at $\$ 1,565$, debts of $\$ 2,082$, and average net worth of $\$ 9,483$ when they started farming. From the stand point of net worth, they were the best off of any temure group. At the close of 1955 they had asset valued at $\$ 19,612$, liabilities of $\$ 5,176$, and average net worths of $\$ 4,436$. In the three-year perlod (1953 to 1955) they had increased their net worth $\$ 4,953$, or 52.2 per cent. The increase was the greatest dollar gain, but not as great a percentage gain as that made by crop-share renters, who increased thoir net worth $\$ 3,279$, or 78 per cent. Apparently gain in net worth is related to tenure status, but control of total assets may be more important than land ownership, particularly where the farm business is too mall for optimum combination of resources. In terms of dollars, the partoveners had the largest increase in net worth. There is scarcely any difference in the dollar increase of livestock-ahare and crop-share tenants. The owner-operators had the smallest incresse in net worth, both dollarmalse and percentagendse.

Total indebtedness.-The greatest portion of the debts of these men was secured by mortgages on farm real estate. Onmer and partoveer operators had larger debts than other tenure groups. Iosns to 


\section{TABLE XXXIV}

Total Assets, Labilities and Net Worth of Beginning Farmers in Fifteen Northern Missourl and Fourteen Southern Iow Counties, According to Type of Tenure When They Started Farming, in January 1 , 1953 and December 31, 1955.

\begin{tabular}{|c|c|c|c|c|c|c|c|c|c|c|c|c|}
\hline \multirow[b]{2}{*}{ It em } & \multicolumn{2}{|c|}{ Onmer } & \multicolumn{2}{|c|}{ Part-Owner } & \multicolumn{2}{|c|}{ Cash } & \multicolumn{2}{|c|}{ Crop-Share } & \multicolumn{2}{|c|}{$\begin{array}{c}\text { Crop } \\
\text { Share-Cash } \\
\end{array}$} & \multicolumn{2}{|c|}{$\begin{array}{c}\text { Iivestock } \\
\text { Share }\end{array}$} \\
\hline & $\begin{array}{c}\text { Jan. } 1 \\
1953 \\
\end{array}$ & $\begin{array}{c}\text { Dec 31 } \\
1955 \\
\end{array}$ & $\begin{array}{r}\text { Jan } 1 \\
1953 \\
\end{array}$ & $\begin{array}{c}\text { Dec 31 } \\
1955 \\
\end{array}$ & $\begin{array}{r}\text { Jan I } \\
1953 \\
\end{array}$ & $\begin{array}{c}\text { Dec 31 } \\
1955 \\
\end{array}$ & $\begin{array}{r}\text { Jan } 1 \\
1953 \\
\end{array}$ & $\begin{array}{c}\text { Dec 31 } \\
1955 \\
\end{array}$ & $\begin{array}{r}\text { Jan I } \\
1953 \\
\end{array}$ & $\begin{array}{c}\text { Dec 31 } \\
1955 \\
\end{array}$ & $\begin{array}{r}\text { Jan I } \\
1953 \\
\end{array}$ & $\begin{array}{c}\text { Dec } 31 \\
1955 \\
\end{array}$ \\
\hline \multicolumn{13}{|l|}{ ASSETS: } \\
\hline Machinery & $\$ 1062$ & $\$ 2223$ & $\$ 1353$ & $\$ 2941$ & $\$ 667$ & $\$ 1683$ & $\$ 1063$ & $\$ 2503$ & $\$ 1378$ & $\$ 2803$ & $\$ 1040$ & $\$ 2628$ \\
\hline $\begin{array}{l}\text { Crops, feed } \\
\text { and supplies }\end{array}$ & 338 & 700 & 112 & 1935 & 466 & 984 & 106 & 1222 & 330 & 1554 & 498 & 1781 \\
\hline Livestock & 908 & 1838 & 1494 & 3053 & 1050 & 2633 & 528 & 2006 & 919 & 3062 & 1100 & 3002 \\
\hline $\begin{array}{l}\text { Total farm } \\
\text { operating assets }\end{array}$ & 2308 & 4761 & 2959 & 7929 & 2183 & 5300 & 1697 & 5731 & 2627 & 7419 & 2638 & 7422 \\
\hline $\begin{array}{l}\text { Farm real } \\
\text { estate assets }\end{array}$ & 5215 & 7508 & 4559 & 8565 & & 550 & & 1134 & & 295 & 62 & 708 \\
\hline $\begin{array}{l}\text { TOTAL RARM } \\
\text { ASSETS }\end{array}$ & $\$ 7523$ & $\$ 12269$ & $\$ 7518$ & $\$ 16494$ & $\$ 2183$ & $\$ 5850$ & $\$ 1697$ & $\$ 6865$ & $\$ 2627$ & $\$ 774$ & $\$ 2700$ & $\$ 8119$ \\
\hline $\begin{array}{l}\text { TOTAL NONFARM } \\
\text { BUSINESS ASSETS }\end{array}$ & $\$ 792$ & $\$ 192$ & $\$ 37$ & & $\$ 50$ & $\$ 16$ & $\$ 100$ & $\$ 123$ & $\$ 237$ & $\$ 32$ & $\$ 63$ & $\$ 60$ \\
\hline
\end{tabular}

Continued 
TABLE XXXIV, Continued

Total Assets, Liabilities and Net Worth of Beginning Farmers in Flfteen Northern Missouri and Fourteen Southern Iow Counties, According to Type of Temure When They Started Farming, in January 1, 1953 and December 31, 1955.

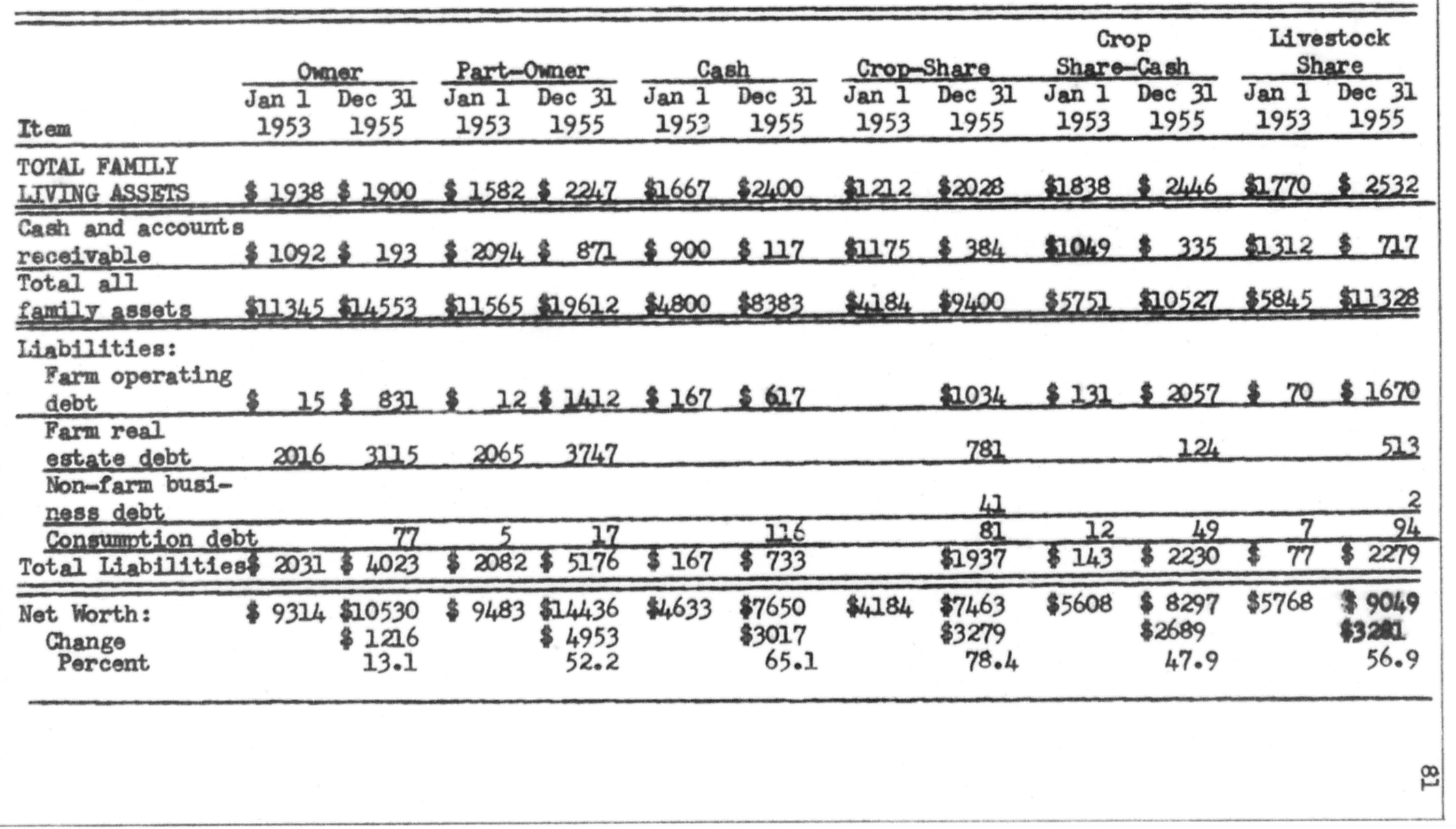


pay operating expenses were the second largest group. The average amount of debt of all groups increased between 1953 and 1955. However, the Increase was considerably less than the gain in sasets. Cropshare tenants increased their total indebtedness 80.2 per cent in the three-year period.

Net worth.-Partmowers had the largest gain in net worth in terms of dollars. Their equities averaged \$9,483 in 1953 and $\$ 4,436$ in 1955 for an increase of $\$ 4,953$, or 52.2 per cent. Crop-share tenants had the smallest net worth when they started farming (only $\$ 4,284$ ), and at the close of $1955(\$ 7,463)$, but they had the largest percentage increase ( 78.4 per cent).

The average increase in net worth for the 152 men was $\$ 3,136$. This vas a 51.7 per cent gain. The average gain for each tenure group was: (1) part-oveners, $\$ 4,953$ or 52.2 per cent; (2) 11vestock-shere lease holders $\$ 3,281$ or 56.9 per cent; (3) crop-share renters, $\$ 3,279$ or 78.4 per cent; (4) cash renters, $\$ 3,016$ or 65.1 per cent; (5) cropshare cash, $\$ 2,689$ or 47.9 per cent; and (6) ovmen-operators, \$2, 216 or 13.1 per cent. Three ovener-perators, one part-ovener, 4 crop-ahsre tenants, 2 crop-eharemash renters, and 3 livestock-share lesse holders had decreases in net worth during the three-year period. Non-Real Estate Gredit

Twenty operators did not use credit in 1955. The other 132 had 284 loans. Of this number, 145 were new loans secured in 1955, while 239 were carried over from 1954.

As shown in Table XXXV, 132 men borrowed an avarage of $\$ 2,9 / 42$. 


\section{TABLE XXXV}

Average Interest Rate, Terms, and Amount of Non-Real Bstate Credic Used During 193s by Beginning Farners in Fissour and Fourteen Southem Iowa Counties, According to Type or Tenure When Borrower Started Farming in 1933

\begin{tabular}{|c|c|c|c|c|c|c|c|}
\hline It em & $\begin{array}{l}\text { Onmer } \\
\text { Operator }\end{array}$ & $\begin{array}{l}\text { Part } \\
\text { Owner }\end{array}$ & Casn & $\begin{array}{l}\text { Crop } \\
\text { Snare } \\
\end{array}$ & $\begin{array}{l}\text { Crop Snare } \\
\text { Casn } \\
\end{array}$ & $\begin{array}{l}\text { Livestock } \\
\text { Share } \\
\end{array}$ & $\begin{array}{c}\text { All Tenure } \\
\text { Groups }\end{array}$ \\
\hline Number usding credit & 12 & 11 & 0 & 20 & 37 & 40 & 132 \\
\hline Number or losns & 28 & 2) & 11 & $\infty 0$ & $\$ 0$ & 84 & 284 \\
\hline $\begin{array}{l}\text { Average interest } \\
\text { rate (percent) }\end{array}$ & 3.4 & 3.2 & 3.0 & 3.9 & 3.0 & 3.8 & 4.4 \\
\hline $\begin{array}{l}\text { Average term } \\
\text { (months) }\end{array}$ & 8.3 & 4.0 & 13.0 & 8.4 & 11.9 & 7.7 & 8.8 \\
\hline $\begin{array}{l}\text { Average amount } \\
\text { borrowed I/ }\end{array}$ & $\$ 1915$ & $\$ 2188$ & $\$ 1707$ & $\$ 1902$ & $\$ 3281$ & $\$ 2190$ & $\$ 23>3$ \\
\hline
\end{tabular}


Grops-share-cash tenants borrowed the largest amount, or $\$ 3,281$. Livestock-share tenants were second with an average of $\$ 2,796$. Partowners, crop-share renters, owner-operators, and cash tenants borrowed $\$ 2,188, \$ 1,962, \$ 1,915$, and $\$ 1.767$ respectively.

The average interest rate paid by the various tenure groups was as follows: (1) crop-share-cash tenants, 5.6 per cent; (2) owneroperators, 5.4 per cent; (3) cash renters, 5.0 per cent; (4) crop-share tenants, 3.9 per cent; (5) livestock-share lease holders, 3.8 per cent; and (6) part-owmers, 3.2 per cent. The average rate of all tenure Broups was 4.4 per cent.

The average length of the loans was 8.8 months, for all temure groups. Cash tenants had the longest term loans, 13 months. Ioans to part-owners averaged 4.6 months in length.

Source, interest rates and temure.-Commercial banks were the major source of credit. One hundred thirty of the 284 loans were obtained from this source. The average interest rate was 5.8 per cent. The coimercial bank loans averaged $\$ 1,2 /, 1$, and were for an average term of 9.4 months.

Family credit was the second major source in 1955. Fortymone of 284 loans were from this source. Twenty-eight were for an indefinite period, and ald not have an interest charge. The aversge amount per Ioan was $\$ 1,500$.

Merchants were the third major source of credit, according to number of loans. Thirty-seven of the $284_{4}$ were secured from merchants. Nine were vdthout interest charge, and were for an indafinite tarm. 
Twenty-six loans had an average interest charge of 5.9 per cent, and ware for average terms of 14.1 months. The average amount was $\$ 489$. Twenty-five of the loans were obtained from the Parmers Home Adninistration. The average interest charge was 4.7 per cent. The average length was 41.7 months. The average amount borrowed vas $\$ 2,188$.

The avarage interest rate for loans from all sources was 2.3 per cent, with an average term of 4.7 months. The average amount per loan mas $\$ 1,363$.

Security. - Information as to type of security given by the borrower for the 284 loans made in 1955 was obtalned for 262 of the contracts. Two-fifths of those for which information was obtained were made without security. Family menbers cosigned notes for 22; 68 were secured by chattel mortgages on the items purchased with the funds. S1xteen were secured by chattel mortgages on the item purchased and other property. Forty-six were secured by mortgages on property previouly ovmed. Five were secured by liens on real estate. Real Bstate Gredit.

One omer-pperator, two part-owners, one holder of a livestockshare lease, and one crop-share tensnt purchased land in 1955. Three of these men bought because farm ovnership was a major goal. Two bought for farm enlargement. Four of the buyers used mortgages and one a purchase contract to acquire land. Three of the sellers were retired, and two were active farmers.

The average value of the acquired land was $\$ 8,100$. Two men did 
not make a down payment. One paid cash for the land he bought. The Iivestock-share tenant made a $\$ 500$ down peyment, and the crop-share tenant pald $\$ 5,000$ down.

The average interest rate was 4.25 per cent. The average length of loan was 23.8 years. Totsl Amount Borrowed

The average amount borrowed for all purposes in 1955, by tenure groups, was as follows: (1) ovener-operators, \$4,436; (2) part-owners, $\$ 6,424$, (3) cash tenant s, \$1,850; (4) crop-share renters, \$2,775; (5) crop-share-cash tenants, \$3,327; and (6) livestock-share leese holders, \$3,411. The average amount vas \$3,713.

Farm real estate credit averaged $\$ 1,159$ for the 152 operators. Men who started as owmer-operators in 1953 borrowed \$3,631; partovmers borrowed \$4,235; cash tenants, \$83; crop-share renters, \$813; crop-share-cash, \$130; and 11vestock-share tenants, \$545.

The average amount of credit used by these beginning farmars Increased $\$ 1,394$ per man in the 1953-55 three-year period. Farm real estate credit incressed $\$ 46$, or 56 per cent. Credit needs grew larger as the businesses were expanded. Most of the men could have obtained wore credit if they had so desired. Gredit Refusals

Only three operators were refused eredit in 1955. The reasons were insufficient security.

\section{Off-Farm Work}

Nore than one-hale ( 57.9 per cent) of the operators worked aray from their farms in 1955. The average income from this source was 
$\$ 1,063$ per man. These men spant an average of 3.2 months doing offfarm work. Some of them worked on other farms; some did unskilled work in other industrles (Table XXVVI).

The 7 owner-operators who worked off their farms received an average of $\$ 2,071$ for 5.3 months of thedr time. They spent more time awa from their businesses than did any other tenure group.

Ten, or 58.8 per cent of the part owners worked an average of 3.6 months off their farms. The average amount earned was \$953.

Two-thirds of the cash tensints did off-farm work. They earned an sverage of $\$ 530$ for 2.8 months of work.

Nineteen, or 59.3 per cent of the crop share tenants earned an average of $\$ 979$ from off-farm work. The avarage amount of time spent was 3.0 months.

Twenty-four, or 64.8 per cent of the crop-sharemash tenants worked off their farms an average of 2.2 months and earned $\$ 698$. Fifty-one per cent of the livestock-share tenants worked off thedr farms. This was the smallest percentage of any tenure group. The average earnings were $\$ 1,063$ for 3.2 months of their time.

The number of operators working off-farm incressed by 17 from 1953 to 1955. The average earnings per worker incressed from $\$ 973$ to $\$ 1,063$ The average time spent increased from 3.2 to 3.5 months. Operator's wife.-As shown in Table XXXVI, 17 wives worked off the farms. Thedr average earnings were $\$ 1,52$ for 7.9 months of labor. Bookeeping and secretarial work were the major jobs hald. 


\section{TABLS XXXVI}

Type of off-Farm Work Done by 1953 Beginning Farmers and Their Wives in 1955 and Average Receipts From This Source, Fifteen Northern Missouri and Fourteen Southern Iowa Counties.

\begin{tabular}{|c|c|c|c|c|c|c|c|c|}
\hline \multirow[b]{2}{*}{$\begin{array}{l}\text { Type } \\
\text { of } \\
\text { Temure } \\
\end{array}$} & \multicolumn{4}{|c|}{ Operator } & \multicolumn{4}{|c|}{ Wife } \\
\hline & $\begin{array}{l}\text { Number } \\
\text { working }\end{array}$ & $\begin{array}{l}\text { Major type } \\
\text { of off-farm } \\
\text { work I] }\end{array}$ & $\begin{array}{l}\text { Average } \\
\text { total } \\
\text { Income } \\
\end{array}$ & $\begin{array}{l}\text { Average number } \\
\text { of months of } \\
\text { off-farm work }\end{array}$ & $\begin{array}{l}\text { Number } \\
\text { rorking }\end{array}$ & $\begin{array}{l}\text { Major type } \\
\text { of off-farm } \\
\text { work } y\end{array}$ & $\begin{array}{c}\text { Average } \\
\text { total } \\
\text { income } \\
\end{array}$ & $\begin{array}{l}\text { Average number } \\
\text { of months of } \\
\text { off-farm work }\end{array}$ \\
\hline Orener & 7 & $8,7,1$ & $\$ 2,071$ & 5.3 & 1 & 3 & $\$ 3,300$ & 10.0 \\
\hline Part Onner & 10 & 1 & 953 & 3.6 & 3 & 4,3 & 1,387 & 7.7 \\
\hline Cash & 4 & 1 & 530 & 2.8 & 1 & 4 & 2,250 & 12.0 \\
\hline Grop Share & 19 & $1,6,8$ & 979 & 3.0 & 3 & 4,5 & 1,447 & 9.0 \\
\hline $\begin{array}{c}\text { Grop Share } \\
\text { Cesh }\end{array}$ & $2 / 4$ & 1,7 & 698 & 2.2 & 4 & 5,4 & 1,043 & 6.3 \\
\hline $\begin{array}{l}\text { Ifivestock } \\
\text { Share }\end{array}$ & $2 / 4$ & 1,7 & 1,333 & 3.5 & 5 & 4,3 & 1,444 & $7 \cdot 4$ \\
\hline $\begin{array}{l}\text { Total or } \\
\text { Average }\end{array}$ & 88 & & $\$ 1,063$ & 3.2 & 17 & & $\$ 1,52$ & 7.9 \\
\hline $\begin{array}{l}\text { 1/ Farm wor } \\
2 / \text { Agricult } \\
3 / \text { Bducatio } \\
\text { 4/ Bookkeep } \\
5 / \text { Public }\end{array}$ & $\begin{array}{l}\text { wal servi } \\
\text { ing and se } \\
\text { rvice (no }\end{array}$ & ceretarial & $\begin{array}{l}\text { 6/ Publs } \\
\text { I/ Indus } \\
\text { 8/ Indus } \\
\text { // Prive }\end{array}$ & $\begin{array}{l}\text { c service (skdl) } \\
\text { trial (non-akjl] } \\
\text { trlal (skdlled) } \\
\text { te business }\end{array}$ & ed) & & & \\
\hline
\end{tabular}




\section{Family Assistance}

In 1955, seventy-nine gifts were received by 52 operstors. The average amount per operator was \$578. Livestock-share tenants received 21 of the 79 gifts. The average amount was \$373. Grop-share tonents recedved 26 gifts which averaged $\$ 19$ per gift. Fighteen gifts were recedved by the crop-share-cash tenants, and averaged $\$ 211$ per gift. Part-owners received 9 glfts that averaged $444 ; 6$ gifts were received by cash tenants that averaged $\$ 500$; and one ommer-operator received one gift of $\$ 300$ ( $T a b l e$ VXXVII).

Fiftymeight of the 79 gifts were in the form of unpeld family labor, and use of family chinery. Six were cash gifts. Three were Livestock gifts. Two were machinery, and 6 were feed and seed.

In 1953, 57.9 per cent of the men received family gifts. In 1955 34.2 per cent received gift s. Help declined as the operators became less dependent on family assistance.

\section{Ienure}

Tenure arrangements changed during the 1953-55 three-year period. Three of the 13 who started as owner-operators rented additional land and were part-overs in 1955. Three of the 17 part-ovmers who started farming in 1953 became full ovner-operators by 1955. The 6 cssh tenents were changed to one part-ovener, 2 share-cash renters, and 3 cash tenants in 1955. Two from the 32 crop-share tenants became partoumers, 10 became crop-share-cash tenants, two changed to livestockahare leases, and 18 were still farming with crop-share lesses. One of the 37 crop-share-cash tenants became an ouner-operator; one changed to a cash lease; two obtained livestock-share leases and 33 continued 


\section{TABLE XXXVII}

Type and Amount of Family Help Received by Beginning Farmers During 1955 in Fifteen Northern Missourl and Fourteen Southern Iove Count1es, According to Type of Tenure in 1953.

\begin{tabular}{|c|c|c|c|c|c|c|c|c|c|c|c|c|}
\hline \multirow[b]{2}{*}{ Type of Gifts } & \multicolumn{2}{|c|}{ Owmer } & Part & \multirow{2}{*}{$\begin{array}{l}\text { Omer } \\
\text { Average } \\
\text { amount }\end{array}$} & \multicolumn{2}{|c|}{ Cash } & \multicolumn{2}{|c|}{ Grop Share } & \multicolumn{2}{|c|}{$\begin{array}{c}\text { Crop } \\
\frac{\text { Share Cash }}{\text { Average }}\end{array}$} & \multicolumn{2}{|c|}{$\begin{array}{c}\begin{array}{c}\text { Livestock } \\
\text { Share }\end{array} \\
\end{array}$} \\
\hline & No. & $\begin{array}{c}\text { Average } \\
\text { amount } \\
\end{array}$ & No. & & No. & $\begin{array}{c}\text { Average } \\
\text { amount }\end{array}$ & No. & $\begin{array}{c}\text { Average } \\
\text { amount } \\
\end{array}$ & No. & $\begin{array}{l}\text { Average } \\
\text { amount }\end{array}$ & No. & $\begin{array}{r}\text { Average } \\
\text { amount } \\
\end{array}$ \\
\hline Cash & - & - & 2 & 1350 & - & - & 2 & 2550 & - & - & 2 & 800 \\
\hline Ifvestock & - & - & - & - & - & - & 1 & 300 & 1 & 100 & 1 & 100 \\
\hline Machinery & - & - & - & - & 1 & 1900 & - & - & - & - & 1 & 200 \\
\hline Feed, seed, etc. & - & - & 1 & 100 & 2 & 400 & - & - & - & - & 3 & 800 \\
\hline $\begin{array}{l}\text { Use of fantly } \\
\text { machinery and un- } \\
\text { paid Iamily labor }\end{array}$ & 1 & 300 & 6 & 200 & 1 & 300 & 19 & 216 & 17 & 218 & $u_{4}$ & 229 \\
\hline $\begin{array}{l}\text { Farm real } \\
\text { estate }\end{array}$ & - & - & - & $=$ & $=$ & - & - & - & - & - & - & - \\
\hline $\begin{array}{l}\text { Household } \\
\text { goods }\end{array}$ & - & - & - & - & - & - & 4 & 350 & - & - & - & $=$ \\
\hline
\end{tabular}

Total number

getes and

300

$9-4+4$

$\begin{array}{llllllll}4 & 750 & 26 & 419 & 18 & 211 & 21 & 357\end{array}$


to farm under crop-share-cash leases. Two of the 47 livestock-share tenants became owner-operators; one became a partmovner; one a cash renter, three changed to arop-share-cash leases, and 40 remained livestock-share tenants.

The number in each tenure group in 1955 was as follows: (1)

owner-operators, 16; (2) part-ovners, 27; (3) cash renters, 5; (4) crop-share tenants, 18; (5) crop-share-cash, 48; and (6) livestockshare, 44. Changes from 1953 were an increase of 3 owner-operators, 4 part-ovmers, and 11 crop-share-cash tenants. Cash, crop-share and livestock-share tenants decreased one, $\nu_{4}$, and 3 respectively. Farm owmership still appears to be a major goal of many operators. Lessing Arrangements

Seventy-two of the 136 men who were renters obtained one tract. Forty-one operators secured two tracts. Fighteen men rented 3, and 5 rented 4 tracts. Sixteen omer-operators did not rent land in 1955. As shown in Table XXXVIII, 62, or 46.3 per cent of the men had oral leases on all of the land they rented. Fifty-two operators had written leases. Many of them were obtained while the lesse holder was enrolled in the on-the-farm training program. However, only 38.8 per cent of the tenants had uritten lesses on all of the land they rented. Fourteen per cent had written lesses on part of the land they rented. The number of men with veitten leases had increased since 1953. Fifteen additional operators had veritten lesses on part or all of their rented land, as compared with the situation in 1953.

Sixty-eight of the 129 men reporting did not have compensation clauses in their leases in 1955. Fifty-four had compensation clauses 


\section{TABLE XXXVIII}

Parcentage of Operators Who Started Farming in 1953 Who Had Written, Oral, and Mixed Leases in That Year and In 1955, Fifteen Northern Missouri and Fourteen Southers Iow Count1es.

\begin{tabular}{|c|c|c|c|c|c|c|c|c|c|c|}
\hline \multirow[b]{2}{*}{$\begin{array}{l}\text { Tenure } \\
\text { Group }\end{array}$} & \multicolumn{4}{|c|}{$1953 \mathrm{I} /$} & \multicolumn{3}{|c|}{ Types of Leases } & \multicolumn{2}{|c|}{$19552 /$} & \multirow[b]{2}{*}{ Total } \\
\hline & $\begin{array}{l}\text { No } \\
\text { Rented } \\
\text { Land } \\
\end{array}$ & Oral & Written & $\begin{array}{c}\text { Both Oral } \\
\text { and } \\
\text { Written }\end{array}$ & Total & $\begin{array}{l}\text { No } \\
\text { Rent ed } \\
\text { Land }\end{array}$ & Oral & Written & $\begin{array}{c}\text { Both Oral } \\
\text { and } \\
\text { Written }\end{array}$ & \\
\hline Owner-operator & 100 & - & - & - & 100 & 83 & 17 & - & - & 100 \\
\hline Part-owner & - & 71 & 29 & - & 100 & 18 & 59 & 23 & - & 100 \\
\hline Cash renter & - & 67 & 33 & - & 100 & - & 50 & 33 & 17 & 100 \\
\hline $\begin{array}{l}\text { Crop Share } \\
\text { Tenant }\end{array}$ & - & 74 & 26 & - & 100 & - & 53 & 34 & 13 & 100 \\
\hline $\begin{array}{l}\text { Crop share } \\
\text { Cash Tenant }\end{array}$ & - & 25 & 64 & 11 & 100 & 2 & 22 & 57 & 19 & 100 \\
\hline $\begin{array}{l}\text { Livestock Share } \\
\text { Tenant s }\end{array}$ & - & 62 & 23 & 15 & 100 & 5 & 48 & 30 & 17 & 100 \\
\hline $\begin{array}{l}1 / 150 \text { reporting } \\
2 / 150 \text { reporting. }\end{array}$ & & & & & & & & & & \\
\hline
\end{tabular}


in all of their leases, and seven in the leases on a part of their rented land (Table XXXIX).

Labor share arrangement s.-Twenty-five men had labor share arrange ments in 1953 and 16 in 1955, as shown in Table XI. In 1953, 9 men were contributing labor and some of the working capital. In 1955, 14 were operating with agreement $s$ of this kind.

In 1953, 16 men were contributing labor only wille working with their parents. Six men were contributing labor and some of the working capital. Labor share arrangements decreased from 1953 to 1955. This change was in the direction of progress up the agricultural ladder. As men become better established in a farm business, they are able to supply a greater proportion of the capital, and they receive a greater share of the returns.

Iivestock-share tenants had the largest per cent of labor share arrangements in 1953. In 1955, crop-share tenants ware the highest group, 15.6 per cent having labor share arrangements. Livestock-ahare tenants were second highest, with 14.9 per cent.

Nost valuable tract rented.-Sixtymeight of the 135 tenants reporting had written leases on the most valuable tract they were renting in 1955; 67 had oral leases.

Forty-five men had indefinite term leases. Seventy operators held one-year contracts. One had a two-year lease, 17 had three-year contracts, and 8 had a flve-year lease.

Seventy-one of the 131 tenants reporting did not have compensation clauses in their lesses. Seventy-two of the 136 tenants were 


\section{TABLE XXXIX}

Number of Operators Without Conpensation Mlauses and Percentage With Compensation Clauses in Lesses in 1955 by Tenure Croups and Type of Tenure When They Started Farming in 1953, F1fteen Northern Missourl and

Fourteen Southern Iow Counties.

(Number of operators in tenure group)

\begin{tabular}{|c|c|c|c|c|c|c|c|}
\hline It em & $\begin{array}{l}\text { Owner } \\
\text { Operator }\end{array}$ & $\begin{array}{l}\text { Part } \\
\text { Ormer }\end{array}$ & Cash & $\begin{array}{l}\text { Crop } \\
\text { Share }\end{array}$ & $\begin{array}{c}\text { Crop Share } \\
\text { Cash }\end{array}$ & $\begin{array}{c}\text { Livestock } \\
\text { Share }\end{array}$ & Total 기 \\
\hline $\begin{array}{l}\text { No compensation } \\
\text { clause }\end{array}$ & 1 & 4 & 5 & 21 & 15 & 22 & 68 \\
\hline
\end{tabular}

Percent of land rented

with compensation

clause in lease:

$$
\begin{gathered}
0-19 \\
20-39 \\
40-59 \\
60-79 \\
80-99 \\
100
\end{gathered}
$$

No rented land

Total

10

\section{1}

3

15

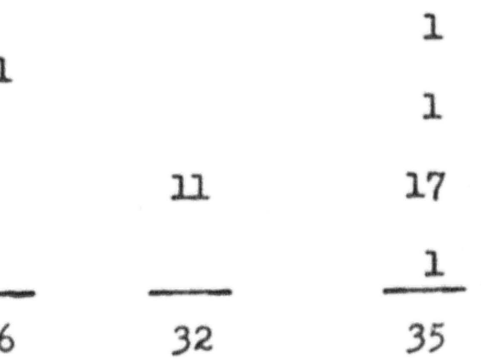

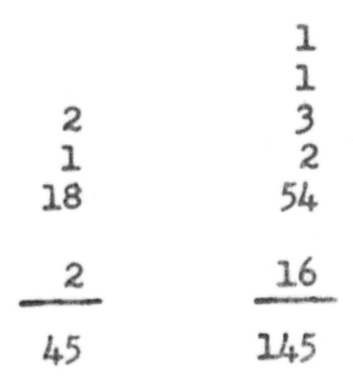

If One hundred forty-five reporting. 
TABLE XI

Number of Operators who Started Farming in 1953 With Different Types of Labor Agreements in 1955, According to Type of Tenure at the TIme They Started, FIfteen Northern Missouri and Fourteen Southern Iowa Counties.

\begin{tabular}{|c|c|c|c|c|c|c|c|c|c|c|c|}
\hline \multirow[b]{3}{*}{$\begin{array}{l}\text { Tenure } \\
\text { Group }\end{array}$} & \multirow[b]{3}{*}{$\begin{array}{l}\text { No } \\
\text { Iabor } \\
\text { Share } \\
\end{array}$} & \multicolumn{5}{|c|}{$\begin{array}{c}1953 \\
\text { Land Ormer }\end{array}$} & \multirow[b]{3}{*}{$\begin{array}{l}\text { No } \\
\text { Labor } \\
\text { Share }\end{array}$} & \multicolumn{4}{|c|}{$\begin{array}{c}1955 \\
\text { Land Ormer } \\
\end{array}$} \\
\hline & & & Parent & $\begin{array}{l}\text { Other } \\
\text { Rela- } \\
\text { t1ve }\end{array}$ & $\begin{array}{l}\text { Non } \\
\text { Rela- } \\
\text { tive }\end{array}$ & $\begin{array}{l}\text { Non } \\
\text { Rela- } \\
\text { tive } \\
\end{array}$ & & \multicolumn{2}{|c|}{ Parent } & $\begin{array}{l}\text { Other } \\
\text { Relative }\end{array}$ & $\begin{array}{c}\text { Non } \\
\text { Relat1re } \\
\end{array}$ \\
\hline & & $\begin{array}{l}\text { Labor } \\
\text { only }\end{array}$ & $\begin{array}{l}\text { Operat } \\
\text { Labor and } \\
\text { parts of } \\
\text { working } \\
\text { capital }\end{array}$ & $\begin{array}{l}\text { Labor } \\
\text { only }\end{array}$ & $\begin{array}{l}\text { polles } \\
\text { Labor } \\
\text { only }\end{array}$ & $\begin{array}{l}\text { Labor and } \\
\text { parts of } \\
\text { working } \\
\text { capdtal }\end{array}$ & & $\begin{array}{l}\text { Labor } \\
\text { only }\end{array}$ & $\begin{array}{l}\text { Oper } \\
\text { Labor and } \\
\text { parts of } \\
\text { working } \\
\text { capital } \\
\end{array}$ & $\begin{array}{l}\text { cator suppl } \\
\text { Labor and } \\
\text { parts of } \\
\text { working } \\
\text { capital }\end{array}$ & $\begin{array}{l}\text { Les } \\
\text { Labor and } \\
\text { parts of } \\
\text { working } \\
\text { capital } \\
\end{array}$ \\
\hline $\begin{array}{l}\text { Onener- } \\
\text { operator }\end{array}$ & 13 & & & & & & 13 & & & & \\
\hline Part-owener & 15 & 1 & 1 & & & & 15 & & 2 & & \\
\hline Cash renter & 5 & & 1 & & & & 5 & & 1 & & \\
\hline $\begin{array}{l}\text { Grop-share } \\
\text { tenant }\end{array}$ & 26 & 4 & 1 & & 1 & & 27 & 1 & 3 & & 1 \\
\hline $\begin{array}{l}\text { Crop-share } \\
\text { cash tenant }\end{array}$ & 36 & 1 & & & & & 36 & 1 & & & \\
\hline $\begin{array}{l}\text { IAvestock- } \\
\text { share } \\
\text { TOMAL }\end{array}$ & $\frac{32}{127}$ & $\frac{10}{16}$ & $\frac{3}{6}$ & $\frac{1}{1}$ & 1 & $\frac{1}{1}$ & $\frac{40}{136}$ & 2 & $\frac{5}{11}$ & $\frac{1}{1}$ & $\frac{1}{2} \quad$ v \\
\hline
\end{tabular}


related to the owner of the most valuable tract. The overs of 46 of the most valuable tracts were active farmers who lived within 50 miles of the farm. Thirty-two men rented from retired farmers who lived within 50 miles. Twenty-nine obtained land from a nonfarm person within 50 miles. Twenty-three men rented from a nonfarm person residing more than 50 miles avay. The dominant type of owner of the most valuable rented tract was an active farmer residing within 50 miles of the farm (Table XII).

Second most valuable tract.-Twenty-one of the 64 men renting more than one tract of land had written leases on the second most valuable tracts. Nineteen had indefinite tern leases; 38 had one-year contracts; two held two-year leases; two three-years, and two, fiveyear leases.

Twenty-eight of the 64 men held leases which contained compensation clauses. Twenty-seven were related to the owner of the second most valuable tract rented.

The dominant type of owner of the second most valuable tract was an active farmer residing wdthin 50 miles of the farm. Retired farmers residing within 50 miles of the farm were the second major type.

Important sources of land.-As show in Table XIII, 57 of the 146 men reporting considered farms owned by parents as the most important source of land. Obtaining land by having a personal acquaintance with the landlord wo considered the most important source by 45 men. People who own farms give first praference to members of their family and second preference to farmers or prospective farmers in the community. These same two sources were considered 


\section{TABILE XII}

Type of Ovener of Nost Valuable Tracts Rented by Beginning Farmers in Fifteen Northern If Missourl and Fourteen Southern Iow Counties During 1955, (Number of Operators in Bach Tenure Group)

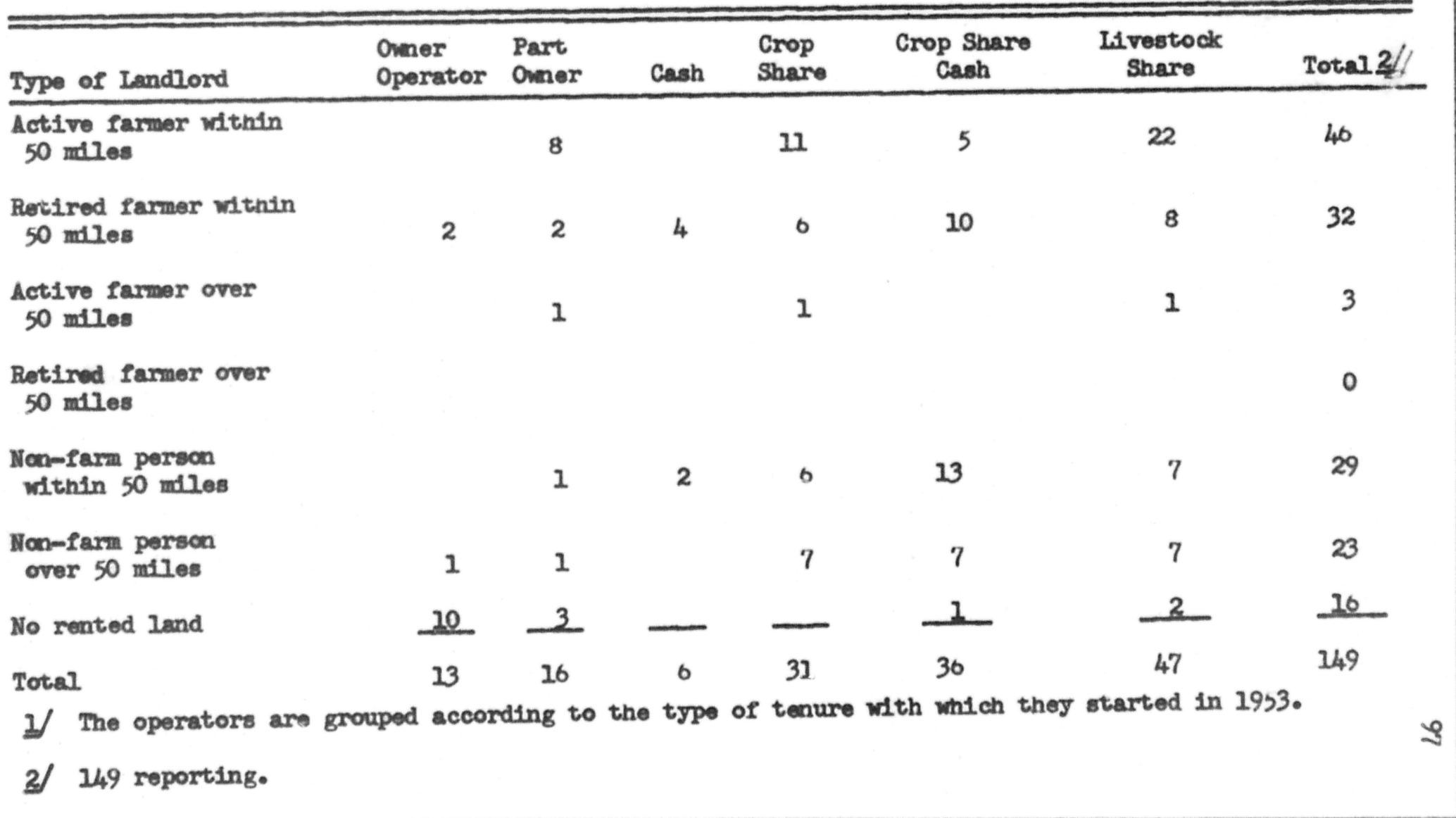




\section{TABLE XIII}

Most Important Source of Land Farmed by Beginning Farmers in Fifteen Northern Missouri and Fourteen Southern Iowa Counties During 1955, by Type of Tenure When They Started Farming in 1953.

(Number of Operators in Each Tenure Group)

\begin{tabular}{|c|c|c|c|c|c|c|c|}
\hline Source of Land & Ormer & $\begin{array}{l}\text { Part } \\
\text { Ovener } \\
\end{array}$ & Cash & $\begin{array}{l}\text { Grop } \\
\text { Share } \\
\end{array}$ & $\begin{array}{c}\text { Grop Share } \\
\text { Cash } \\
\end{array}$ & $\begin{array}{c}\text { Livestock } \\
\text { Share }\end{array}$ & Total \\
\hline Ormed by parents & & 7 & 4 & 11 & 4 & 31 & 57 \\
\hline Rented by parents & & 1 & & 1 & & & 2 \\
\hline $\begin{array}{l}\text { Owned by other } \\
\text { relatives }\end{array}$ & & & & 1 & 1 & 2 & 4 \\
\hline $\begin{array}{l}\text { Rented by other } \\
\text { relatives }\end{array}$ & & & & & & & 0 \\
\hline $\begin{array}{l}\text { Rented through } \\
\text { relatives' help }\end{array}$ & & & & & 9 & 3 & 12 \\
\hline Inherited & 1 & 2 & & & & & 3 \\
\hline $\begin{array}{l}\text { Bought with } \\
\text { family aid }\end{array}$ & 3 & 2 & & & & 2 & 7 \\
\hline $\begin{array}{l}\text { Bought without } \\
\text { family ald }\end{array}$ & 9 & 3 & & 2 & 1 & 1 & 16 \\
\hline $\begin{array}{l}\text { Obtained through personal } \\
\text { acqualintance with land- } \\
\text { lord }\end{array}$ & $\ldots$ & 2 & 2 & 15 & 19 & 7 & 45 \\
\hline Total & 13 & 17 & 6 & 30 & 34 & 46 & 146 \\
\hline
\end{tabular}


most important in 1953.

Twenty-six of the 54 men farming two or more tracts consider ed land obtained through personal acquaintance with the over as the second most important source (Table XIIII). Fleven men considered the use of land ovmed by their parents the seoond most important source. Net Farm Income

As shown in Table XIIV, the net farm incones of part-owmers uas the highest among the various tenure groups. They recelved an average of $\$ 2,241$. Crop-share renters recelved $\$ 1,828$; crop-share-cash tenants, \$1,700; Iivestock-share lesse holders, \$1,61]; owner-operators $\$ 1,069$; and cash renters, $\$ 1,050$.

The average net farm income was larger for ownem-operators, partowners, and crop-share tenants in 1955 than in 1953. The increase in land values was a major factor in a higher net farm income for owneroperators and part-owmers. Low hog prices in the fall of 1955 was a major reason for the decline in Iivestock-share tenants' net farm income (Table 1, Appendix A).

Despite the fact that businesses were larger, the net farm operating income was smaller in 1955 than in 1953 for all groups except the crop-share tenants. Average gross receipts from livestock and farm produce sales are shown in Table KIV.

All groups except crop-share tenants sold more livestock and farm produce in 1955 then in 1953. Crop-share tenants sold \$1,706 worth of farm produce in 1953, and $\$ 1,622$ in 1955. The farm businesse\$ of all groups were larger in 1955 than in 1953. 


\section{TABLE XIIII}

Second Yost Important Source or Land Farmed by Beginning Farmers in FIfteen Northern Missourl and Fourteen Southern Iowa Counties During 1955, by Type or Tenure When They Started Farming in 1953, (Number of Operators in Each Tenure Group)

\begin{tabular}{|c|c|c|c|c|c|c|c|}
\hline Source of Ind & Onner & $\begin{array}{l}\text { Part } \\
\text { Oner }\end{array}$ & Cash & $\begin{array}{l}\text { Crop } \\
\text { Share } \\
\end{array}$ & $\begin{array}{l}\text { Crop Share } \\
\text { Cash }\end{array}$ & $\begin{array}{c}\text { If vestock } \\
\text { Share }\end{array}$ & Totel \\
\hline Ovened by parents & & 2 & & 2 & 5 & 2 & บ1 \\
\hline Rented by parents & & & & 1 & 1 & 2 & 4 \\
\hline $\begin{array}{l}\text { Ovened by other } \\
\text { relatives }\end{array}$ & & 1 & & 1 & & & 2 \\
\hline $\begin{array}{l}\text { Rented by other } \\
\text { relatives }\end{array}$ & & & & & & & 0 \\
\hline $\begin{array}{l}\text { Rented through } \\
\text { relatives' help }\end{array}$ & & & & & & & 0 \\
\hline Innerited & & 1 & & & & & 1 \\
\hline $\begin{array}{l}\text { Bought with famdly } \\
\text { ald }\end{array}$ & & 5 & 1 & & & & 6 \\
\hline $\begin{array}{l}\text { Bought without } \\
\text { fandly ald }\end{array}$ & & 4 & & & & & 4 \\
\hline $\begin{array}{l}\text { Obtained through personal } \\
\text { acquaintance with land- } \\
\text { lord }\end{array}$ & 3 & 2 & - & 7 & 2 & 5 & 26 \\
\hline Total & 3 & 15 & 1 & 11 & 15 & 9 & 54 \\
\hline
\end{tabular}




\section{TABTE XITV}

Average Net Income of Families tho Started Farming in 1953 by Sources and Tenure Groups, F1fteen Northern Milssouri and Fourteen Southern Iowa Counties I

\begin{tabular}{|c|c|c|c|c|c|c|}
\hline Income & Oumer & $\begin{array}{l}\text { Part } \\
\text { Ormer }\end{array}$ & Cash & $\begin{array}{l}\text { Crop } \\
\text { Share }\end{array}$ & $\begin{array}{c}\text { Crop Share } \\
\text { Cash } \\
\end{array}$ & $\begin{array}{c}\text { If vestock } \\
\text { Share }\end{array}$ \\
\hline $\begin{array}{l}\text { Net farm operating } \\
\text { income }\end{array}$ & $\$ 500$ & $\$ 1,494$ & $\$ 1, \infty 00$ & $\$ 1,784$ & $\$ 1,676$ & $\$ 1,581$ \\
\hline $\begin{array}{l}\text { Net farm real } \\
\text { estate income } 2 /\end{array}$ & 369 & 747 & 30 & 44 & $2 / 4$ & 30 \\
\hline Net fam income & 1,009 & $2,24,2$ & $1,0,0$ & 1,828 & 1,100 & 1,1, \\
\hline OrI rarm income & 1,869 & 1,353 & 883 & 1,075 & 819 & 1,089 \\
\hline Girts & 23 & 235 & 500 & 341 & 103 & 160 \\
\hline Net frunliy income & $\$ 2,961$ & $\$ 3,829$ & $\$ 2,433$ & $\$ 3,244$ & $\$ 2,022$ & $\$ 2,800$ \\
\hline
\end{tabular}

II Incomes are for the 1955 calendar year.

2/ Increased value of owned farm real estate during 1935. 


\section{TABLE $X \perp V$}

Gross Recelpts From the Sale of Lfvestock and Other Farm Products By Farmers Who Started in Business in 1953, Fifteen Northern Missouri and Fourteen Southern Iowa Counties, During 1953 and 1955.

\begin{tabular}{|c|c|c|c|c|c|c|}
\hline \multirow[b]{2}{*}{$\begin{array}{l}\text { Tenure } \\
\text { Group }\end{array}$} & \multicolumn{3}{|c|}{$\begin{array}{c}1953 \\
\text { Source of Income }\end{array}$} & \multicolumn{3}{|c|}{$\begin{array}{c}1955 \\
\text { Source of Income }\end{array}$} \\
\hline & $\begin{array}{l}\text { Livestock } \\
\text { Sales }\end{array}$ & $\begin{array}{l}\text { Other } \\
\text { Farm } \\
\text { Produce } \\
\text { Sales } \\
\end{array}$ & Total & $\begin{array}{l}\text { Livestock } \\
\text { Sales }\end{array}$ & $\begin{array}{l}\text { Other } \\
\text { Parm } \\
\text { Produce } \\
\text { Sales } \\
\end{array}$ & Total \\
\hline $\begin{array}{l}\text { Onner } \\
\text { Operators }\end{array}$ & $\$ 908$ & $\$ 1,231$ & $\$ 2,139$ & $\$ 1,638$ & $\$ 1,415$ & $\$ 3,053$ \\
\hline Part-Owners & 1,865 & 1,465 & 3,330 & 3,494 & 2,035 & 5,529 \\
\hline Cash Renters & 933 & 1,333 & 2,266 & 1,350 & 1,500 & 2,850 \\
\hline $\begin{array}{l}\text { Crop Share } \\
\text { Tenants }\end{array}$ & 850 & 1,706 & 2,556 & 2,116 & 1,622 & 3,738 \\
\hline $\begin{array}{l}\text { Crop Share } \\
\text { Cash Tenants }\end{array}$ & 1,181 & 1,508 & 2,689 & 3,542 & 1,994 & 5,535 \\
\hline $\begin{array}{l}\text { Luvestock } \\
\text { Share } \\
\text { Tenant s }\end{array}$ & $\$ 1,851$ & $\$ 996$ & $\$ 2,847$ & $\$ 3,117$ & $\$ 1,428$ & $\$ 4,545$ \\
\hline
\end{tabular}




\section{Off-Farm Income}

Many of the famflies who started farming in 1953 obtained a part of their income from off-farm sources. The average amount for all tenure groups except part-owners was greater in 1955 than in 1953. Apperently these people felt the need for more income, and it was easier to obtain from off-farm sources than by incressing farm earnings. The average amount was greatest for owner-perators $(\$ 1,869)$, and least for crop-share-csis tenants (\$819). Comparisons of returns from offfarm sources in 1953 and 1955 are presented in Table XIVI. The data Include the earnings of wives as well as returns to the farm operators.

The average contribution to off-farm income by wives of owneroperators was \$254; part-owners' wives earned $\$ 245$; livestock-share lease holders \$154; crop-share renters, \$136; cash renters, \$375; and crop-share-cash tenants, \$113.

When the average contribution of the wives was subtracted from the off-farm income, the average per operator for each tenure groups was: (1) owmem-operators, \$1,615; (2) part-owners, \$1,108; (3) livestock-share lease holders, \$935; (4) crop-share tenants, \$939; (5) cash renters, \$508; and (6) crop-share-cash tenants, \$706. Gifts

Gifts were of less importance in 1955 than in 1953. Cash tensnts received the greatest amount in 1955. The average was \$500. Cropshare tenants received \$34l; part-owners, \$235; livestock-share lease holders, \$160; crop-share-cash renters, \$103; and owner-operators, \$23. Net Family Income

Net family incomes in 1955 were greater for owner-operators and 


\section{TABLE XIVI}

Comparison of Off-Farm Incomes of Beginning Farmers For The Years of 1953 and 1955, Fifteen Northern Missourl and Fourteen Southern Iow Counties.

\begin{tabular}{lcc}
\hline \hline $\begin{array}{l}\text { Tenure } \\
\text { Group }\end{array}$ & $\begin{array}{c}\text { Average } \\
1953\end{array}$ & 1955 \\
\hline Owmer-Operators & 931 & 1,869 \\
Part-Ovmers & 729 & 1,353 \\
Cash Renters & 1,167 & 883 \\
Crop Share Tenants & 678 & 1,075 \\
Crop Share Cash Tenants & 613 & 819 \\
Livestock Share Tenants & 660 & $\$ 1,089$
\end{tabular}

I Includes both operator and wife. 
crop-share tenants than in 1953. The other tenure groups had smaller incomes in 1955 than in 1953.

The average net fambly income for 1955 was $\$ 3,829$ for partowners; $\$ 3,244$ for crop-share renters; $\$ 2,961$ for owner-operators; $\$ 2,860$ for livestock-share lease holders; $\$ 2,622$ for crop-share-cash renters, and $\$ 2,544$ for cash tenants (Table XIIV).

As shovm in Table XIVII, net farm income made up the largest share of the net family income for all groups except owmer-operators. Sixtythree per cent of ower-operators' net fanlly income came from offfarm sources. Approximately 33.0 per cent of the net returns of other groups came from off-farm sources.

Gifts made up 20.5 per cent of the net famlly income of cash tenants. The next h1ghest percentage wa 10.5 per cent for crop-share tenant s.

Labor Income to Family, Iabor Income to Operstor, and Return to Management

As shown in Table XIVIII, labor incomes to the family were greatest for crop-share tenants. In 1955 they averaged \$1,744. Partowners were second, with averages of $\$ 1,718$. Owner-operators had the smallest labor incomes with averages of $\$ 692$.

Iabor incomes to operators, as shown in Table XIVIII, were highest for crop-share tenants and part-owners. Ownermoperators received the smallest amount s.

Positive returns to magement were obtained by crop-share renters and part-owners. The other tenure groups received negative returns to management (Table XIVIII). 


\section{TABLE XIVII}

Composition of Net Family Incomes of Beginning Farmers in FIfteen Northern Missourl and Fourteen Southern Iows Counties During 1955, by Type of Tenure When They Started Farming in 1953

\begin{tabular}{|c|c|c|c|c|c|c|}
\hline Item & $\begin{array}{l}\text { Ovener } \\
\text { Operator }\end{array}$ & $\begin{array}{l}\text { Part } \\
\text { Ormer }\end{array}$ & Cash & $\begin{array}{l}\text { Crop } \\
\text { Share } \\
\end{array}$ & $\begin{array}{c}\text { Crop Share } \\
\text { Cash }\end{array}$ & $\begin{array}{c}\text { Ii.vestock } \\
\text { Share }\end{array}$ \\
\hline $\begin{array}{l}\text { Net farm } 1 \\
\text { Amovint } \\
\text { Percent }\end{array}$ & $\begin{array}{r}\$ 1,069 \\
36.1\end{array}$ & $\begin{array}{r}\$ 2,241 \\
58.5\end{array}$ & $\begin{array}{r}\$ 1,050 \\
43.2\end{array}$ & $\begin{array}{r}1,828 \\
56.4\end{array}$ & $\begin{array}{r}\$ 1,700 \\
64.8\end{array}$ & $\$ \frac{1,011}{50.3}$ \\
\hline $\begin{array}{l}\text { Off farm } 1 \\
\text { Amount } \\
\text { Percent }\end{array}$ & $\begin{array}{r}\$ 1,809 \\
03.1\end{array}$ & $\begin{array}{r}\$ 1,353 \\
35.3\end{array}$ & $\begin{array}{r}883 \\
30.3\end{array}$ & $\begin{array}{r}\$ 1,013 \\
33.1\end{array}$ & $\begin{array}{r}819 \\
31.2\end{array}$ & $\begin{array}{r}\$ 1,089 \\
38.1\end{array}$ \\
\hline $\begin{array}{l}\text { Gifts: } \\
\text { Amount } \\
\text { Percent }\end{array}$ & $\begin{array}{r}23 \\
00.8\end{array}$ & $\begin{array}{r}235 \\
6.2\end{array}$ & $\begin{array}{r}500 \\
20.5\end{array}$ & $\$ \begin{array}{r}341 \\
10.5\end{array}$ & $\begin{array}{l}103 \\
4.0\end{array}$ & $\begin{array}{l}160 \\
3.0\end{array}$ \\
\hline $\begin{array}{c}\text { Net famtly } \\
\text { Amount } \\
\text { Percent }\end{array}$ & $\begin{array}{r}\$ 2,901 \\
100.0\end{array}$ & $\begin{array}{r}\$ 3,829 \\
100.0\end{array}$ & $\begin{array}{r}\$ 2,433 \\
100.0\end{array}$ & $\begin{array}{r}\$ 3,2 / 44 \\
100.0\end{array}$ & $\begin{array}{r}\$ 2,022 \\
100.0\end{array}$ & $\begin{array}{c}\$ 2,802 \\
100.0\end{array}$ \\
\hline
\end{tabular}




\section{TABIS XLVIII}

Iabor Income to Family, Operator, and Returns to Management, 1953 Beglnning Farmers, Fifteen Northern Mlissour1 and Fourteen Southern Iow Counties, According to Type of Tenure in 1953. I/

\begin{tabular}{|c|c|c|c|c|c|c|}
\hline \multirow[b]{2}{*}{$\begin{array}{l}\text { Tenure } \\
\text { Group }\end{array}$} & \multicolumn{3}{|c|}{1953} & \multicolumn{3}{|c|}{1955} \\
\hline & $\begin{array}{l}\text { Labor Income } \\
\text { to Famdly }\end{array}$ & $\begin{array}{l}\text { Inabor } \\
\text { Income to } \\
\text { Operator }\end{array}$ & $\begin{array}{l}\text { Return to } \\
\text { Management }\end{array}$ & $\begin{array}{l}\text { Lebor Income } \\
\text { to Famfly }\end{array}$ & $\begin{array}{l}\text { Iabor } \\
\text { Income to } \\
\text { Operator }\end{array}$ & $\begin{array}{l}\text { Return to } \\
\text { Management } \\
\end{array}$ \\
\hline Orner-operator & $\$ 508$ & $\$ 392$ & $-\$ 938$ & $\$ 692$ & $\$ 562$ & $-\$ 75$ \\
\hline Part-ovener & 1,829 & 1,724 & +323 & 1,718 & 1,582 & +271 \\
\hline Cash renter & 1,033 & 983 & -317 & 817 & 700 & -700 \\
\hline Crop-share tenant & 1,453 & 1,397 & $f$ & 1,744 & 1,653 & $f 494$ \\
\hline $\begin{array}{l}\text { Crop-share-cash } \\
\text { tenant }\end{array}$ & 1,819 & 1,716 & +403 & 1,438 & 1,332 & -70 \\
\hline $\begin{array}{l}\text { Ifivestock-share } \\
\text { tenant }\end{array}$ & 1,947 & 1,811 & $f 434$ & 1,330 & 1,179 & -185 \\
\hline
\end{tabular}

I The data are for the 1953 and 1955 calendar years. 
In 1953, only omer-operators and cash tenants had negative returns to management, as shown in Table XIVIII. Crop-share tenants made the greatest improvements, moving from averages of $\$ \$ 9$ in 1953 to $f \$ 494$ in 1955. Part -owners moved from a $f \$ 323$ to a $f \$ 271$. Live stock-share tenants had the greatest declines in returns to management. They moved from $f \$ 434$ in 1953 to $-\$ 185$ in 1955. Cash tenants had the seoond greatest declines, moving from - \$317 in 1953 to - \$700 in 1955.

It has already been pointed out that this group of farmers increased the size of their businesses between 1953 and 1955. Despite this fact, fewer operators recedved positive returns to management in 1955, than in 1953. The data presented in Table I, Appendix A, show that operating expenses were increasing while commodity prices were dealining. The foregoing anglysis is based on net farm income. Family assistance was decressing while off-farm income was increasing. The average 1953 beginning farmer increased his net worth from January 1, 1953, to December 31, 1955, by $\$ 3,136$. These were not exceptional years, either from the standpoint of crop ylelds or farm commodity prices. It appears that it is still possible for a young man to accurmulate capital and to become established in farming.

\section{FACTORS WHTCH WERE TESTED STATISTICALLY}

The primary objectives of this study were (1) to determine how young people started farming in 1953, and (2) to reveel the factors that were most influentisl in their success. 
Changes in net worth from January 1, 1953, to December 31, 1955, according to beginning tenure were tested. The single classification analysis of variance was used. The among to within ratio was 2.92, wich was significant at the 5 per cent level. In other words, temure status does appear to be a factor in success. The part-owners differed significantly from the over-operators.

Eleven factors were tested in an effort to discovery why beginning tenure gave a significant difference in change in net worth.

The value of glfts received in 1953 was tested, based on beginning tenure. The among to within ratio was 1.82, which was not statistically signtelcant.

Off-farm income for 1953 was tested, based on beginning tenure. The amongwithin ratio was .48566 , which wa not statisticaly signieicant.

The years of formal education, based on beginning tenure, was tested. The among to within ratio was 1.22 , which was not statistically significant.

The 1953 net farm Income was tested according to beginning tenure. The among to within ratio wa 3.22 , which was barely significant at the 1 per cent level. The part-owners and livestock-share tenants differed significantly from the omer-operators.

The 1953 net family income, which was composed of net farm income, gifts, and off-farm income was tested, based on beginning tenure. The among to within ratio wa 3.45 , wich was statistically significant at the I per cent level. The part-owners and livestock-share tenants differed significantly from the ovmer-operators. 
The 1953 beginning net worth was tested, based on begining tenure. The among to within ratio was 6.21 , wich statiatically algificant at the I per cent level. The part-owners and owner-operators differed significantly from the other tenure groups. There is an indieation that a large beginning net worth is not necessarily associated with large gains in net worth. Part-ovmers with beginning net worth of $\$ 9,483$ gained rapidly; owmer-operators with equities of $\$ 9,314$ did not.

The influence of acres of aropland, which included row crops, grain crops, hay, and rotation pasture, was tested, basod on beginning tanure. The among to vithin ratio wes 3.79 , wich was statistically signflicant at the 1 per cent level. The crop-share-cash, livestockshare, and part-owers differed signflcantly from the ovmer-operators and cash tenants.

The acres of corn, wheat and soybeans harrested in 1953 was tested, based on beginning tenure. The among to within ratio was 3.90 which was stat1stically significant at the I per cent level. The part-owers differed afgificantly from the owner-operators and cash tensnt 8. The crop-share, livestock-share, and crop-share-cash tenants differed significantly from the cash tenants.

The number of total acres controlled by the operator in 1953 was tested, based on beginning tenure. The among to within ratio was 4.14 wich was statisticaly significant at the 1 per cent level. The Iivestock-share tensnts differed aignificantly from the cash tenants and owner-operators. The part-owers and crop-share-cash tenants differed signficantly from cash tanants. 
The total starting assets under the operator's control were tested, besed on beginning temure. The ratio of among to within was 4.91, which was statistically significant at the 1 per cent level. The livestock and crop-sharemeash tenants differed significantly from the owner-operators. The livestock-share tenants differed significantly from the cash tenants, too.

The 1953 total productive man work unit requirements per man was tested, based on beginning tenure. The among to within ratio was 6.67, which was statistically algniflcant at the $I$ per cent level. The Ifvestock-share tenants differed significantly from the owneroperators and crop-share tenants. The crop-share tenants differed significantly from the crop-share-cssh tenants.

The ovenemerators' net farm income and net family income were significantly different from part-owners in 1953. The beginning net worth for part-owners and owner-operators were significantly different from the other tenure groups. Evidently the owner-operators did not have a large emugh volume of business to obtain an adequate farm income. Nost of the other factors tested indicated that the owneroperators atarted on small, inadequate farm units.

MAJOR' SUCCESS AND FAIIURE FACTORS FACED BY BEGINNING FARMERS

Many factors determine success or failure in becoming established in farming. Some can be controlled by the individual, others can not. Important among those that can be controlled are size of business, praductivity of the soil, farm experience, skill in management, and 
efficient use of land, captial and labor. Factors that are beyond the control of the individual include weather conditions, heelth, costs, farm commodity prices, and lack of farming opportunities when the Individual is at the age to start farming. Risk and uncertainty of the future may be modified through careful selection and management of enterprises, but cannot be removed antirely. They must be considered in plans to become established in farming.

\section{Success Factors Reported}

BIghty-sdx of the 152 men who furnished data for this study named a factor which they considered to be most important in getting started in farming. Twenty-two thought availabillty of the family farm to be the most important. Nineteen men considered sufficient nonfamily credit to be the factor of greatest importance. Off-farm income wes the most important to eight men. Use of family machinery and/or livestock was considered the most important by edght men. Onthe-farm training and income that accompanied it was the most important to 4 men, while gifts and inheritance were the most important for 3 men.

The men also were asked to list the second major factor contributing to their success. Eleven of the 86 reporting did not list a second factor. Ten men reported that sufficient non-fanfly credit was the second most important. Nine men listed use of family machinery and Ifvestock. Fight operators stated the use of the fandly farm was the second major factor. Family credit or family-backed credit was the second major factor for 7 men. Off-farm income was the second most important factor for 6 men. Three men stated on-the-farm 
training and the income that accompanied it wes the second most important factor. Three men listed gifts and inheritances.

\section{Factors Limiting Success}

As shown in Table XIIX, 39 men of the 110 reporting stated that Low prices received for their products was a major factor limiting their success. Weather was reported to be the major factor by 36 men. These 75 men, or 68.0 per cent of those reporting, believed that factors outside their control were largely responsible for their slow financial progress. No doubt these men felt that they had adjusted all the factors under their control to enhance their chance for success. This may not be a sound assumption. It has already been pointed out that a high proportion of the beginning farmers started with small businesses. Family labor was not fully employed and the cost of operating equipment per acre or per hour of use was high.

Lack of credit a major limiting factor for 9 men. Lack of avallable land reported by 8 men. Seven men felt that their low beginning net worth was the reason they did not progress rapidly. They were unable to bring together an optimum combinstion of production factors. Poor family heelth was considered by 5 men to be the major factor limiting their success. Only 3 men stated that lack of manarial ability limited their success.

When asked if there was a second major factor limiting their success, 27 of the 107 men repoyting on this item said there was none. Low prices was the second factor for 33 men, as show in Table L. Twenty-seven men said weather was the second factor limiting their 


\section{TABLE XITX}

The Most Important Factor Ijmiting the Success of Beginning Farmers in Fifteen Northern Missouri and Fourm teen Southem Iow Counties, by Type of Tenure When They Started Farming in 1933, (Number of Operators in Bach Tenure Group

\begin{tabular}{|c|c|c|c|c|c|c|c|}
\hline Factor & $\begin{array}{l}\text { Ovener } \\
\text { Operator }\end{array}$ & $\begin{array}{l}\text { Part } \\
\text { Owner }\end{array}$ & Cash & $\begin{array}{l}\text { Crop } \\
\text { Share } \\
\end{array}$ & $\begin{array}{l}\text { Crop Snare } \\
\text { Casn } \\
\end{array}$ & $\begin{array}{c}\text { If vestock } \\
\text { Share }\end{array}$ & Total \\
\hline Lack or Credit & 1 & & 1 & 2 & 4 & 1 & 9 \\
\hline Low Beginning Net Worth & 1 & 1 & & 1 & 2 & 2 & 7 \\
\hline Iack of Land & 1 & 1 & & & 0 & & 8 \\
\hline Iack or Machinery & & & & 1 & 1 & & 2 \\
\hline Iack or IAvestock & & & & & 1 & & 1 \\
\hline $\begin{array}{l}\text { Iimited Management } \\
\text { Ability }\end{array}$ & & 1 & & & 1 & 1 & 3 \\
\hline Prices & & 3 & 2 & 9 & 8 & 17 & 39 \\
\hline Weather & 1 & 3 & 2 & 9 & 8 & 11 & 30 \\
\hline Health and IIness & 1 & 2 & & & & 2 & 5 \\
\hline Total & 3 & 13 & 3 & 22 & 31 & 34 & 110 \\
\hline
\end{tabular}




\section{TABLE I}

Second Najor Factor Limiting the Success of the Beginning Farmers In Fifteen Northem Missourl and Foun teen Iowa Counties, by Type or Tenure When They Started Farming in 1953, (Number of Operators in Each Tenure Group)

\begin{tabular}{|c|c|c|c|c|c|c|c|}
\hline Factors & $\begin{array}{l}\text { Ormer } \\
\text { Operator }\end{array}$ & $\begin{array}{l}\text { Part } \\
\text { Ormer }\end{array}$ & Cash & $\begin{array}{l}\text { Crop } \\
\text { Share } \\
\end{array}$ & $\begin{array}{c}\text { Crop Share } \\
\text { Cash }\end{array}$ & $\begin{array}{l}\text { Livestock } \\
\text { Share }\end{array}$ & Total \\
\hline None & 2 & 4 & 1 & 8 & 2 & 10 & 27 \\
\hline Lack of credit & & & & 1 & 1 & & 2 \\
\hline Low beginnting net wortn & 1 & & & & & 2 & 3 \\
\hline Iack of Iand & & & 1 & 3 & 1 & 3 & 8 \\
\hline Lack or machinery & & & 1 & & 2 & & 3 \\
\hline Lack of I1vestock & & & & & 1 & & 1 \\
\hline Management abdity & & & & & & & 0 \\
\hline Prices & 2 & 7 & 2 & 7 & 9 & 0 & 33 \\
\hline Weather & & 1 & 1 & 2 & 11 & 12 & 27 \\
\hline Health and sickness & & & & 1 & 1 & 1 & 3 \\
\hline Total & 3 & 12 & 0 & 22 & 28 & 34 & 107 \\
\hline
\end{tabular}


success. Lack of available land was reported by 8 men. Lack of machinery, livestock, credit, and Iow beginning net worth were reported by small numbers of those responding to the question. 


\section{CHAPTER IV \\ SUMMARY AND CONCLDSIONS}

\section{Summary}

Getting established in farming has never been an easy task. It is not easy today. A modern commercial farm business requires a large investment. Few beginners have funds to set up an efficient operating unit. Superior managerial ability is necessary to operate an efflcient modern farm business. Technological advances, perticularly in crop production, have forced the farmer to operate a large business in order to get low cost per unit of output. In other words, operating costs are large and returns must be high to meet them.

This study was undertaken to determine how young people are getting started in farming; to find the procedures that are proving to be most successful; and to develop standards that can be used as guides by young people in appraising their chances for success if they make the start with the resources that are available to them.

In order to obtain data for the analysis, a random selection of 112 geographical townhips was made in fifteen Northern Missouri counties and an equal number in fourteen Southern Iows counties. An effort was made to interview all of the farmers in the 224 townships who started operating their businesses in 1953. To be eligible for Interview, a beginning fammer had to meet the following conditions: (1) he must have started farming for the first time in 1953; (2) he 
had to be in position to select or help select the enterprises that were included in the farm business, to make production and meting plans, and to direct farm enterprises which required at least 90 tenhour days of productive labor; (3) he had to be out of full-time formal school before 1953; (4) all or part of his income had to be derived from his contribution to the farm production; and (5) the farm biainess had to be located in the sample township.

One hundred fifty-two records were used in the study. These men began farming for the flrst time in 1953 and were st1ll farming at the close of 1955. Data were obtained covering the 1953, 1954 and 1955 calendar years. The tenure arrangement wdth which the 152 men began farming was as follows: (1) owner-perators, 13; (2) part-owners, 17; (3) cash tenants, 6; (4) crop-share tenants, 32; (5) crops-share-cash tenants, 37; and (6) Iivestock-share tenants, 47.

The operators who were interviewed had attended school an average of 11.7 years. Seventy-aight per cent were high school graduates. Seven college graduates were included. Thirty-six per cent had been 4-H Club members. Fifty-one per cent had taken Vocational Agriculture in high school. The average age when they started to farm was 25.4 years. Seventy-seven per cent were married at the time they began farming. Ninety-four per cent were farm reared. Seventy-seven per cent were veterans, and 18 per cent attended Institutional-on-farm training classes in 1953. Twenty-three per cent received family halp valued at $\$ 500$ or more in 1953. Eleven per cent had recelved $\$ 500$ or more of family help prior to 1953. The parents' farm was the most important source of land used by 48 per cent of the men. 
The operators furnished the beginning capital in most cases, but 6 of the 116 wives furnished the major portion. Savings were the principal method of obtaining beginning capital. The major sources of sevings were earnings from work on their parents' farm, armed services, and industrial labor.

The group had an average of $\$ 19,377$ in farm assets under their control at the time they started farming. The livestock-share tanants controlled farm assets that averaged $\$ 2 / 4,625$ in value, which was the largest for any tenure group. Owner-operators averaged $\$ 7,523$, which was the smallest amount. The average value of farm real estate for the other tenure groups was larger than the total farm assets of the owner-operators.

The 152 men had an average of $\$ 26,035$ in total assets under their control at the time they began farming. The livestock-share tenants averaged $\$ 33,383$, which was the largest amount. Omermperators had an average of $\$ 23,954$, which was the smallest amount.

The aroup had an average of $\$ 6,069$ net worth at the time they began farming. Part-owners had the largest, with an average of $\$ 9,483$. Owner-operators had the second largest, with an average of $\$ 9,314$. Crop-share tenants had an average of $\$ 4,184$, which was the smallest amount. All tenure groups incressed their net worth during 1953. The part-owmers had the largest dollar gain, which averaged $\$ 2,158$, or 22.8 por cent. Livestock-share tenants increased their net worth $\$ 1,404$, or 25.4 per cent. Owmer-operators had the smallest dollar and percentage change. They gained an average of $\$ 301$, or 3.2 per cant. 
The average productive man work unit requirement for the initial ent erprises carried by the 152 men was 221. Ifvestock-share tenants and part-owners had the largest requirements. Owner-operators and crop-share tenants had the smallest requiremants. Productive man work units per man equivalent were particularly low for owner-operators and crop-share tenants. These men were not fully employed on their farms.

Twenty-five per cent of the men did not use non-real estate credit. in 1953. One hundred fourteen operators obtained 166 loans that averaged \$1,441 per loan. Crop-share tenants borrowed the largest amounts. The borrowed money was used primarily for operating expenses and for purchasing livestock and machinery.

Conmercial banks were the major source of eredit. Seventy-eight of the 166 loans were obtained from this source. The average amount per loan was $\$ 1,291$. The average interest rate was 6.5 per cent, and the average term 8.42 months. Elghty-two of these loans were unsecured. A chattel mortgage on the 1tem purchasod furnished security for 31 loans. A chattel mortgage on an item already owned furnished security for 21 loans. Eighteen loans were secured by a family mamber cosigning the note.

Family loans were the second major source. Thirty-five loans were obtained from family members. The average size was \$1,534. In most cases, the terms were extremely easy. Twenty-five were made without interest and for an indefinite term. Most of the loans obtained from family nembers were unsecured.

Ten men purchased land in 1953. Seven ware mortgage purchases and 3 were purchase contracts. Destre for farm owner ship was the reason 5 
men bought land. Two men had to buy in order to obtain a farm. Uncertainty of tenure was the reason 2 men bought land. Four of the men did not make a down payment. Two were not charged interest. The average rate for the other men was 5.5 per cont.

Seven operators were refused credit in 1953. Four were refused once, and 3 were refused 3 times. Insufficient security was the reason for most of the refusals.

Seventymo men worked off-farm in 1953. The average income from this source was \$973. A higher percentage of the cash tenants, cropshare tenants, and owmer-operators worked off-farm than did the other tenure groups. Custom work and non-skilled industrial labor were the major types of off-farm work.

Eighteen of the 121 wives had off-farm jobs. The average income was $\$ 1,228$.

One hundred thirty-eight gifts were received by 88 operators. The average amount per operator was \$769. Iivestock-share tenants received the largest number of gifts. Owner-operators received the smallest number. The major type was use of family machinery and unpaid family labor from relatives who were not members of the operator's immediate family.

Eighty-five of the tenant and part-owner operators rented only one tratt of land; forty-four rented 2 tracts, and 10 rented 3 tracts. Fifty-six per cent, or 77 , of the renters had oral leases on all of the land they rented. Seventy-two did not have compensation clauses in their leases. 
Twenty-ifve men had a labor share arrangement when they began farming. Sixteen operators furnished nothing but labor in a parentson agreement. Ten of these were livestock-share tenants. Six men furnished labor and part of the working capital in parent-son agreement 8. Three of these were livestock-share tenants. Thirty-two per cent of the Hivestock-share tenants had labor share arrangements. This was the greatest percentage of any tenure group.

Having access to family controlled land was very important to the group. Elghty-one of the 137 renters reporting on this 1tem were related to the owner of the most valuable tract rented. Seventy-seven of this number did not have written leases. Fifty-four men had indefinite tarm leases.

The group had an average net family income of $\$ 2,982$. This amount included net farm income, returns from off-farm work, and gifts. The part-owners had the largest net family incomes $(\$ 3,958)$. If vestockshare tenants were second, whth an average of $\$ 3,355$. Owner-operstors had the smallest with an average of $\$ 1,800$.

Net farm income contributed the largest share of net family income for all tenure groups, except owner-operators and cash tenants. The cash tenants had an equal amount of net farm and off-farm income. The owner-operators had more income from off-farm work than the net returns from their farm ent exprises.

The family labor incomes, operators' labor incomes and returns to management ware the largest for livestock-share tenants in 1953. Partowmers had the second largest. Owner-operators and csish tenants had negative returns to mans gement during 1933. 
The size of business in terms of total acres, P.M.W.U., total farm assets, and total assets under the operator's control increased for all tenure groups from 1953 to 1955. The average number of total acres per man in 1955 was 228. This vas an average increase of 32 acres, or 16.3 per cent. Productive man work units averaged 301 per man in 1955, which was a 37.4 per cent increase over 1953. The group had an average of $\$ 28,470$ farm assets under their control. This was a 46.9 per cent increase. Total aseets of all kinds under the operator's control in 1955 averaged $\$ 32,387$, which was a 24.4 per cent increase over 1953.

Use of non-real estate aredit increased from 1953 to 1955. One hundred thirty-two men had 284 loans in 1955. One hundred forty-five of these loans were obtained in 1955. Commercial banks remained the major source of credit, with family credit beding second in importance.

FIve men purchased land in 1955. Four used mortgages and one a purchase contract to acquire the land. The average interest rate was 4.25 per cent. The average length of loan was 23.8 years.

The total amount borrowed, non-real estate and real estate, increased $\$ 1,394$, or 60.1 per cent from 1953 to 1955.

The number of men working off-farm increased by 17, or 23.7 per cent, from 1953 to 1955. The average earnings per off-farm worker incressed from $\$ 973$ to $\$ 1,063$. The average time spent off-farm increased from 3.2 months to 3.5 months.

The number of men receiving family assistance decreased in 1955. In 1953, 88 men recedved 138 gifts averaging $\$ 769$. Fifty-two operators received 79 gifts in 1955 which averaged $\$ 578$ per operator. 
The tenure arrangements changed during the threo-year period. Three of the original 13 owmer-operators rented some additional land and became part-owner operators. Three of the 17 part-owners became full owners. One of the 6 cash tenants became a part-owner, 2 changed to share-cash leases, and 3 remained cash tenants. Two of the 32 cropshare-cash tenants became part-owners; 18 continued to farm under cropshare leases; 10 changed to cropm-share-cash leases; and 2 to Iivestockshare tenants. One of the 37 crop-share-cash tenants became an owner operator; one changed to a cash lease, 33 continued to farm under eropshare-cash contracts, while two became livestock-share tenants. Two of the 47 livestock-share tenant s became owner-operators; one a partowner; one a cash renter; 3 got crop-share-cash contracts; and 40 remained livestock-share tenants in 1955. The total number in each of the tenure groups in $1955 \mathrm{was}$ as follows: (1) owner-operators, 16; (2) part-owners, 21; (3) cash renters, 5; (4) crop-share tenants, 18; (5) crop-share-cash renters, 48, and (6) livestock-share lease holders, 44. The change from 1953 was an increase of 3 owner-perators, 4 partowners, and $I 1$ crop-sharemcash tenants. The number of cash, crop-share and Iivestock-share tenants decreased by one, 14, and 3 respectively.

The number of labor share arrangements decreased from 1953 to 1955. Twenty-five men had labor share arrangements in 1953 as compared to 16 in 1955.

The average not farm income in 1955 was larger for owner-operators part-owners and crop-share tenants than it was in 1953. Net farm income was computed by determining the net farm operating income, plus 
or minus net farm raal estate income. Net farm real estate increased in 1955. This increase was a major factor in the larger net farm income of owner-operators and part - vmers.

The average off-farm income of all tenure groups except partowners was larger in 1955 than in 1953. Even though the average size of their farm businesses increased, the men felt a need for more income. Apparently, it was more convenient to get this additional income from off-farm sources than from farm earnings.

Net family income in 1955 was larger for owmer-operators and for crop-share tenants than in 1953. The other groups had smaller family incomes. Net farm income made up the largest share of the net family income for all groups except owner-operators. Sixty-three per cent of the owner-operators' net family income came from off-farm sources. Approximately 33.0 per cent of the income of other groups was from offfarm sources.

The labor income to the family was smaller in 1955 than in 1953. for all tenure groups except crop-share tenants and owner-operators. Crop-share tenants had an average of $\$ 1,744$, which was the largest among the groups. Owner-operators averaged $\$ 692$, which was the smallest. The 1955 operator' labor income also was smaller than in 2953 for all groups, except crop-share tenants and owner-operators. Positive returns to magement were more difficult to obtain in 1955 than in 1953. Only crop-share tenants and part-owers obtained a positive return to management in 1955. Iow hog prices toward the end of the year was one reason for the decrease. The average size of 
business had increased, but fewer men obtained a positive return to management.

Use of the family farm, gufficient non-family credit, off-farm income, use of family machinery and/or livestock, on-the-farm training, and gifts were the major factors listed by most of the operators as contributing to their success. Iow prices and bad weather were the major factors reported as limiting their success. Other limiting factors were lack of credit, lack of land, low beginning net worth, poor family health, and insufficlent managerial ability.

The average increase in net worth from January 1, 1953, to December 31, 1955, was $\$ 3,136$ per man. The average gain in net worth for each tenure group was: (1) part-omers, \$4,953, or 52.2 per cent; (2) Iivestock-share renters, $\$ 3,281$ or 56.9 per cent; (3) crop-share tenants, \$3,279 or 78.4 per cent; (4) cash renters, $\$ 3,017$ or 65.1 per cent; (5) crop-share-cash, $\$ 2,689$ or 47.9 per cent; and (6) ovneroperators, \$1,216 or 13.1 per cent.

Three oven-operators, or 23.1 per cent; one part-ower, or 5.9 per cent; four crop-share tenants, or 12.5 per cent; two crop-sharecash tenants, or 5.4 per cent; and three 11vestock-share tenants, or 6.3 per cent, had decreases in net worth from January 1, 1953 to December 31, 1955. When considered as a group, 8.6 per cent of the farmers tho started in 1953 had decreases in net worth over the threeyear period. Conelustons

Wost joung men who have limited amounts of capital showld not 
try to start farming as owmer-operators. They have a better chance of success if they start as tenants on good-sized farms and use their Iindted funds for woridng eapital.

It is more difficult to become established in farming if the start is made in a perlod of declining farm prices than in a period of stable or rising prices.

Family help is very important to beginning farmers. The use of the family farm and lenient credit arrangements are two major types of ald that are extremely helpful. However, family help in itself does not guarantee success.

Factors outside the operator's control often limit the success of the beginning farmer. Bad weather and low prices are examples. Off-farm income supplements farm income in a large number of cases. Th1s may be extremely important in the early years of farming, particularly for the operator who has difficulty in setting up a business that requires full use of labor and equipment. In 1955, it appeared to be easter to obtain off-farm income than to increase farm income. If off-farm income opportunities decrease, it will be more difficult for young men to become established in farming vithout substantial family assistance.

The findings indicate that a young man can become established in farming if he can start with an adequate business. 


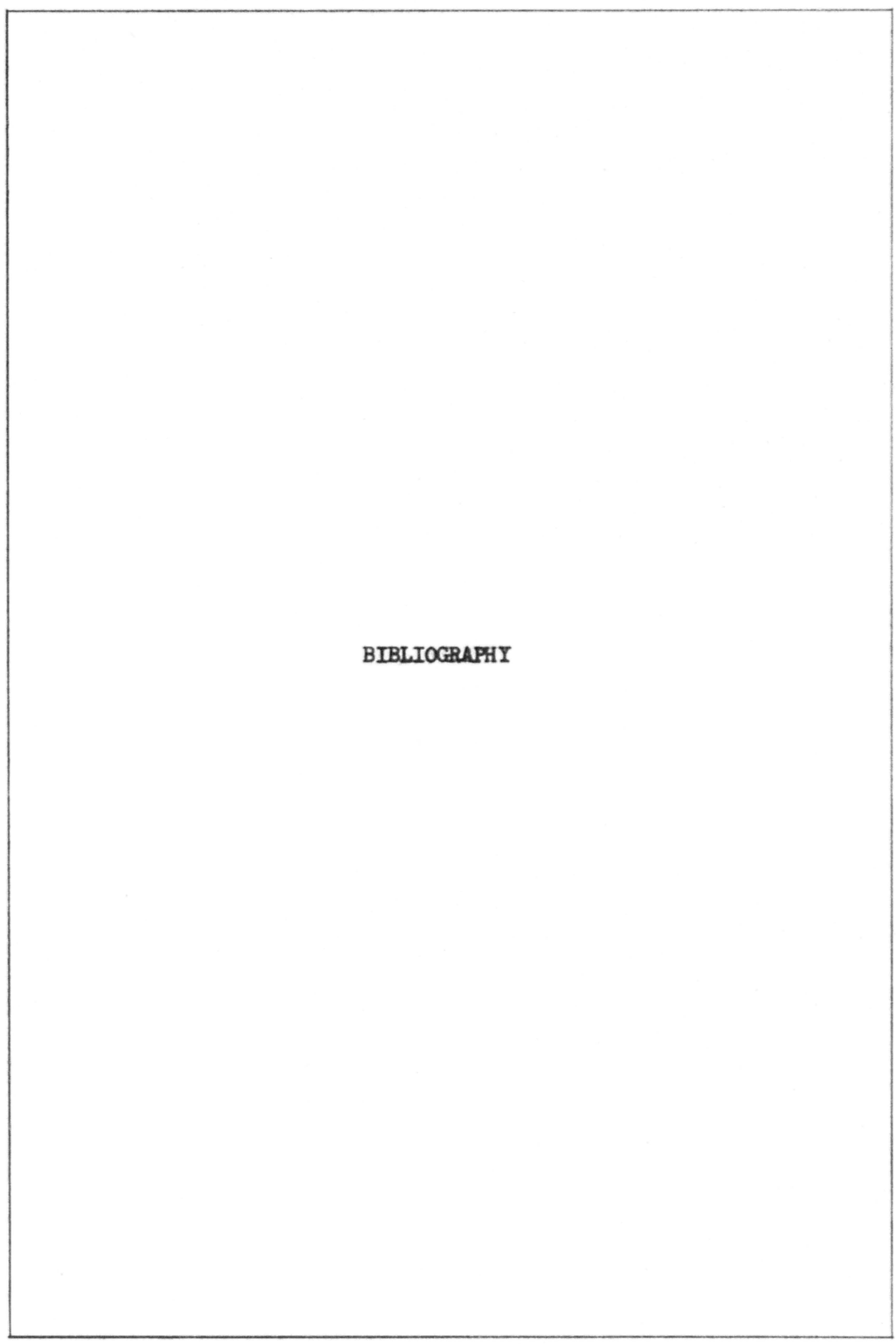


Beneke, Raymond R., and George A. Pond, Starting Farming in Southesstern Minnesots, Und versity of Minnesota Agricult ural Experiment Station Bullotin No. 405, 1950, 20 pp.

Blase, Melvin G., "Procedures for Establishing Farm Businesses in Missouri". Unpublished Master's thesis, University of Milssouri, Columb1a, Missourt, 1956.

Bradford, L. A., nGritical Problems of Young Famdles in Getting Established in Farming", Journal of Farm Economics, Proceedings Number, Vol. 36, No. 5, December 1954 .

Brilef Descriptions of Soll Units for Soil Survers in Iows Soll Conservation Districts, A Report Prepared by the Soll Conservation Service, U. S. D. A., in cooperation with the Iowa Agricultural Experiment Station, Ames, Iowa, 1956, 51 pp.

Hansing, Frank D., "Buylng a Farm With or Without Family Help", The Agricultural Situation, Vol. No. 37, No. 6, June 1953.

Harris, Marshall, "A New Agricultural Ladder", Land Economics, Vol. 3 August 1950.

Hendrix, W. B., Capital Accumulation by Families on Small Farms in the Pledmont, Georgia Agricultural Bxperiment Station Bulletin N. S. 8, 1955, 49 pp.

Lanpher, Buel F., Jr., Productivity of Farm Iand in Missourd, University of Missouri Research Bulletin No. 465 , 1950, 43 pp.

Miller, Frank, and M. F. Miller, The Business of Farming, University of Missouri Agricultural Bxperiment Station Builetin No. 578, 1952, $32 \mathrm{pp}$.

Virler, M. F., and H. H. Krusekopf, The Solls of Missourf, University of Missouri Agricultural Experiment Station Bulletin No. 264, $1929,113 \mathrm{pp}$.

Moore, H. R., and W. A. Wayt, The Part Time Route to Full-Time Farming, Ohio Agricultural Bxperiment Station Research Bulletin No. 793, 1957, 55 pp.

Pond, George A., Henning W. Swanson, and William L. Cavert, Starting Farming Today, University of Kinnesota Experiment Station Bulletin No. $428,1955,36$ pp.

Reiss, F. G., "Dlscussion", Journal 와 Farm Economics, Proceedings Number, Vol. 36, No. 5, December 1954. 
Shaw, Robert H., H. C. S. Thom, and Gerald L. Barger, The Climate of Iowa, Iowa State College Agricultural Experiment Station Special Report No. 8, 1954, 88 pp.

Starrah, J. A., Bablems of Beginning Farmers in Iowa, Iowa State College Research Bulletin No. 313, 1943, 68 pp.

Temperature Normals, A Report Prepared Under the Direction of Charles D. Reed in cooperation with Iowa Department of Agriculture, Des Noines, 1944, 4 pp.

United States Bureau of the Census, U. S. Census of Agriculture; 1954 Vol. I, Counties and State Economic Areas, Part 10. U. S. Government Printing Office, Washington D. C., 1956. 


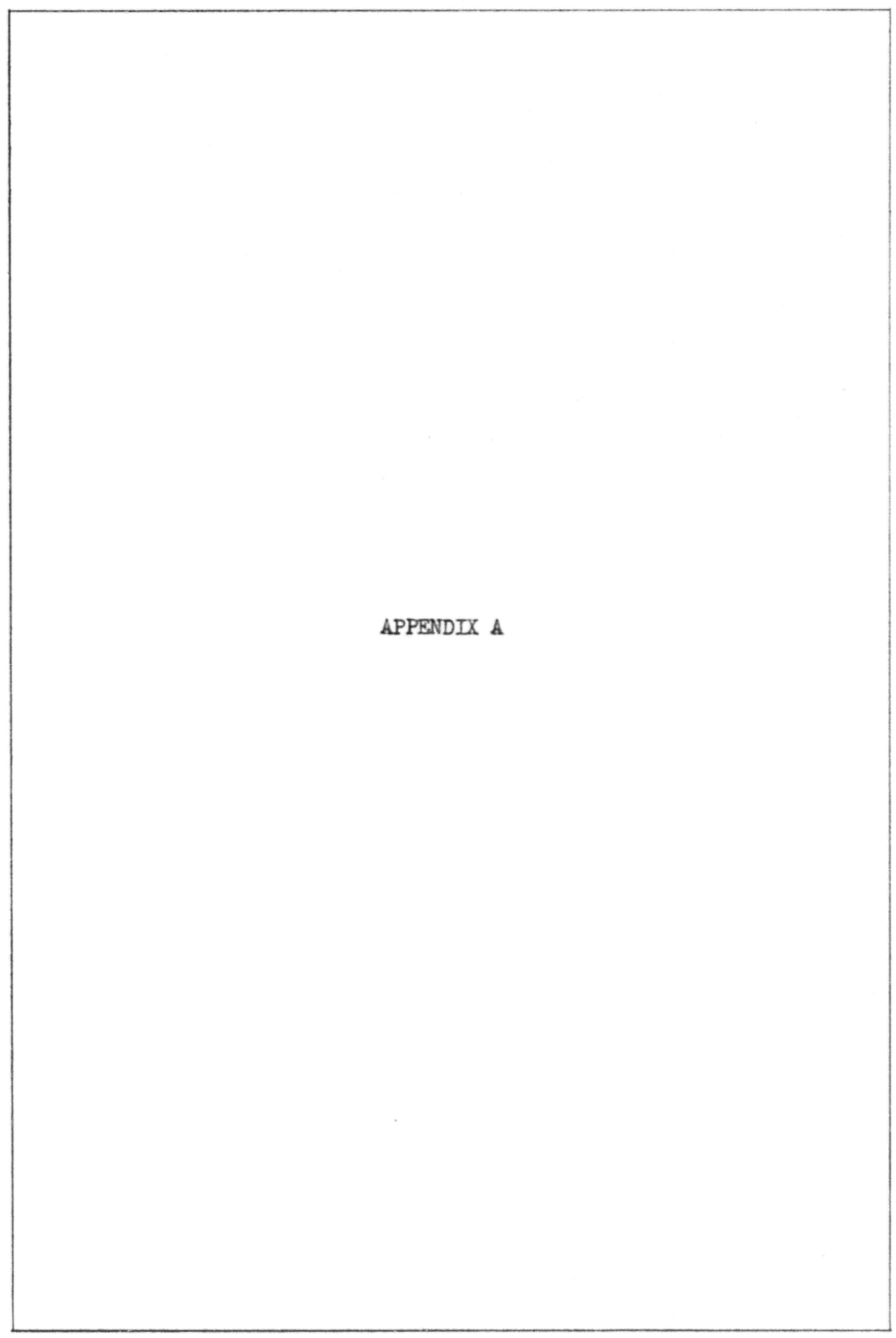


TABLE I

Average Prices Received by Missouri and Iowe Farmers, 1953-1955.

\begin{tabular}{|c|c|c|c|c|c|c|c|}
\hline \multirow[b]{2}{*}{ Commodity: } & \multicolumn{4}{|c|}{ Missouri } & \multicolumn{3}{|c|}{ Iows } \\
\hline & & 53 & 1954 & 1955 & 1953 & 1954 & 1955 \\
\hline Wheat (bu) & $\$$ & $1.94 \$$ & $1.98 \$$ & 1.96 & $1.98 \$$ & $2.03 \$$ & \\
\hline Corn (bu) & & 1.45 & 1.52 & 1.37 & 1.37 & 1.42 & \\
\hline Oats (bu) & & .81 & .78 & .68 & .74 & .74 & \\
\hline
\end{tabular}

$\begin{array}{lllllll}\text { Hay, A I }(T) & 26.43 & 22.98 & 19.58 & 18.61 & 18.78 & 16.74\end{array}$

$\begin{array}{lllllll}\text { Soybesns (bu) } & 2.59 & 2.97 & 2.28 & 2.59 & 3.01 & 2.24\end{array}$

$\begin{array}{lllllll}\text { Hogs (cwt) } \quad 21.77 & 22.31 & 15.80 & 21.47 & 21.67 & 15.01\end{array}$

$\begin{array}{lllllll}\text { Beef Cattle (cwt) } & 16.77 & 16.16 & 16.05 & 19.37 & 19.87 & 18.98\end{array}$

$\begin{array}{lllllll}\text { Veal (cwt) } \quad 18.69 & 17.64 & 18.05 & 18.41 & 17.48 & 16.85\end{array}$

$\begin{array}{llllllll}\text { Sheep (cwt) } & 5.15 & 5.41 & 5.54 & 5.59 & 5.17 & 4.57\end{array}$

$\begin{array}{lllllll}\text { Lambs (cwt) } & 20.17 & 19.79 & 18.71 & 20.26 & 19.60 & 18.93\end{array}$

$\begin{array}{lllllll}\text { Wool (Ib) } & .49 & .49 & .44 & .49 & .49 & .47\end{array}$

$\begin{array}{lllllll}\text { Millk Cow (head) } & 135.50 & 118.33 & 124.16 & 184.83 & 162.08 & 155.00\end{array}$

$\begin{array}{lllllll}\text { Milk }(100 \mathrm{lb}) & 4.01 & 3.63 & 3.72 & 3.82 & 3.52 & 3.48\end{array}$

$\begin{array}{lllllll}\text { Butterfat (1b) } & .58 & .50 & .49 & .7 & .64 & .62\end{array}$

$\begin{array}{lllllllllllllllll}\text { All Chickens (1b) } & .261 & .164 & .210 & .2158 & .180\end{array}$

$\begin{array}{lllllll}\text { Eggs (doz) } & .398 & .288 & .305 & .400 & .277 & .327\end{array}$

Source: Ampicultural Brices, U. S. Department of Agriculture, Agricultural Marketing Service, Crop Reporting Board, Washington, D. C. 
University Libraries

University of Missouri

Digitization Information for Theses and Dissertations project. Scanned from microfilm; no subsequent editing done.

Local identifier

Source information

Identifier

Format

Content type

Notes

Capture information

Date captured

Scanner manufacturer/model ScanPro 3000 /e-ImageData

Scanning software

optical resolution

Compression

Color settings

File types

Notes

Derivatives - Access copy
Microfilm reel\# T1958-98-T1958-109

Microfilm

Text

2019

PowerScan $3000(\mathrm{TM}) \mathrm{v} 5.341$

$600 \mathrm{dpi}$

LZW

bitonal

tiff

Scanned from microfilm; no editing done.
Editing software

Resolution

Color

File types

Notes
Photoshop

600 dpi

grayscale

pdf

Converted from tiff to pdf using Adobe Acrobat Pro DC. 